DOE/ID-22198

Prepared in cooperation with the U.S. Department of Energy

\title{
A Conceptual Model of Ground-Water Flow in the Eastern Snake River Plain Aquifer at the Idaho National Laboratory and Vicinity with Implications for Contaminant Transport
}

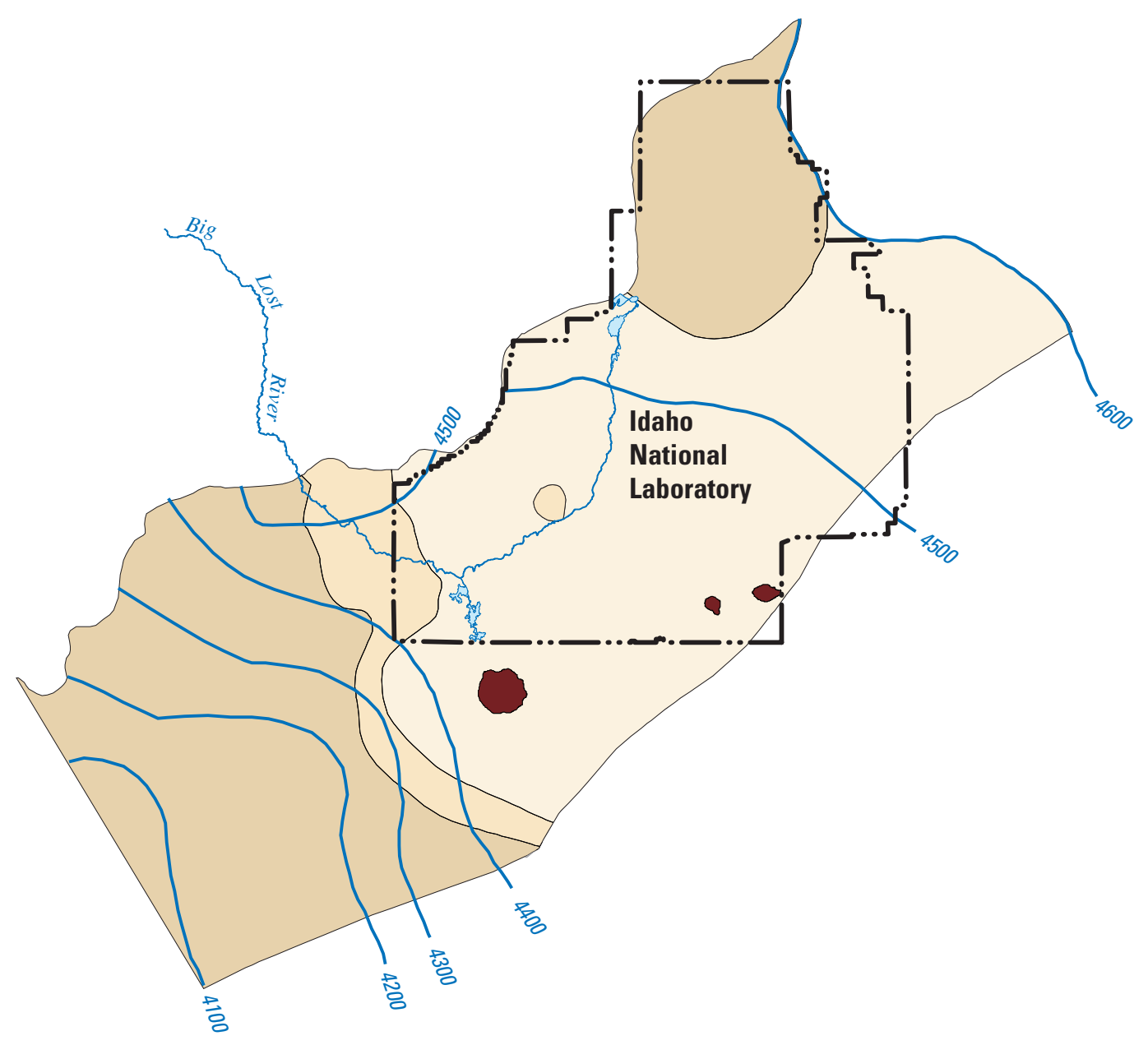

Scientific Investigations Report 2006-5122 
Cover: Map showing distribution of hydrogeologic units present at the water table and water-table contours for 1980 in the model area, Idaho National Laboratory and vicinity, Idaho 


\section{A Conceptual Model of Ground-Water Flow in the Eastern Snake River Plain Aquifer at the Idaho National Laboratory and Vicinity with Implications for Contaminant Transport}

By Daniel J. Ackerman, Gordon W. Rattray, Joseph P. Rousseau, Linda C. Davis, and Brennon R. Orr

Prepared in cooperation with the

U.S. Department of Energy

Scientific Investigations Report 2006-5122 


\section{U.S. Department of the Interior \\ Dirk A. Kempthorne, Secretary \\ U.S. Geological Survey \\ P. Patrick Leahy, Acting Director}

U.S. Geological Survey, Reston, Virginia: 2006

For sale by U.S. Geological Survey, Information Services
Box 25286, Denver Federal Center
Denver, CO 80225
For more information about the USGS and its products:
Telephone: 1-888-ASK-USGS
World Wide Web: http://www.usgs.gov/

Any use of trade, product, or firm names in this publication is for descriptive purposes only and does not imply endorsement by the U.S. Government.

Although this report is in the public domain, permission must be secured from the individual copyright owners to reproduce any copyrighted materials contained within this report.

Suggested citation:

Ackerman, D.J., Rattray, G.W., Rousseau, J.P., Davis, L.C., and Orr, B.R., 2006, A conceptual model of ground-water flow in the eastern Snake River Plain aquifer at the Idaho National Laboratory and vicinity with implications for contaminant transport: U.S. Geological Survey Scientific Investigations Report 2006-5122, 62 p. 


\section{Contents}

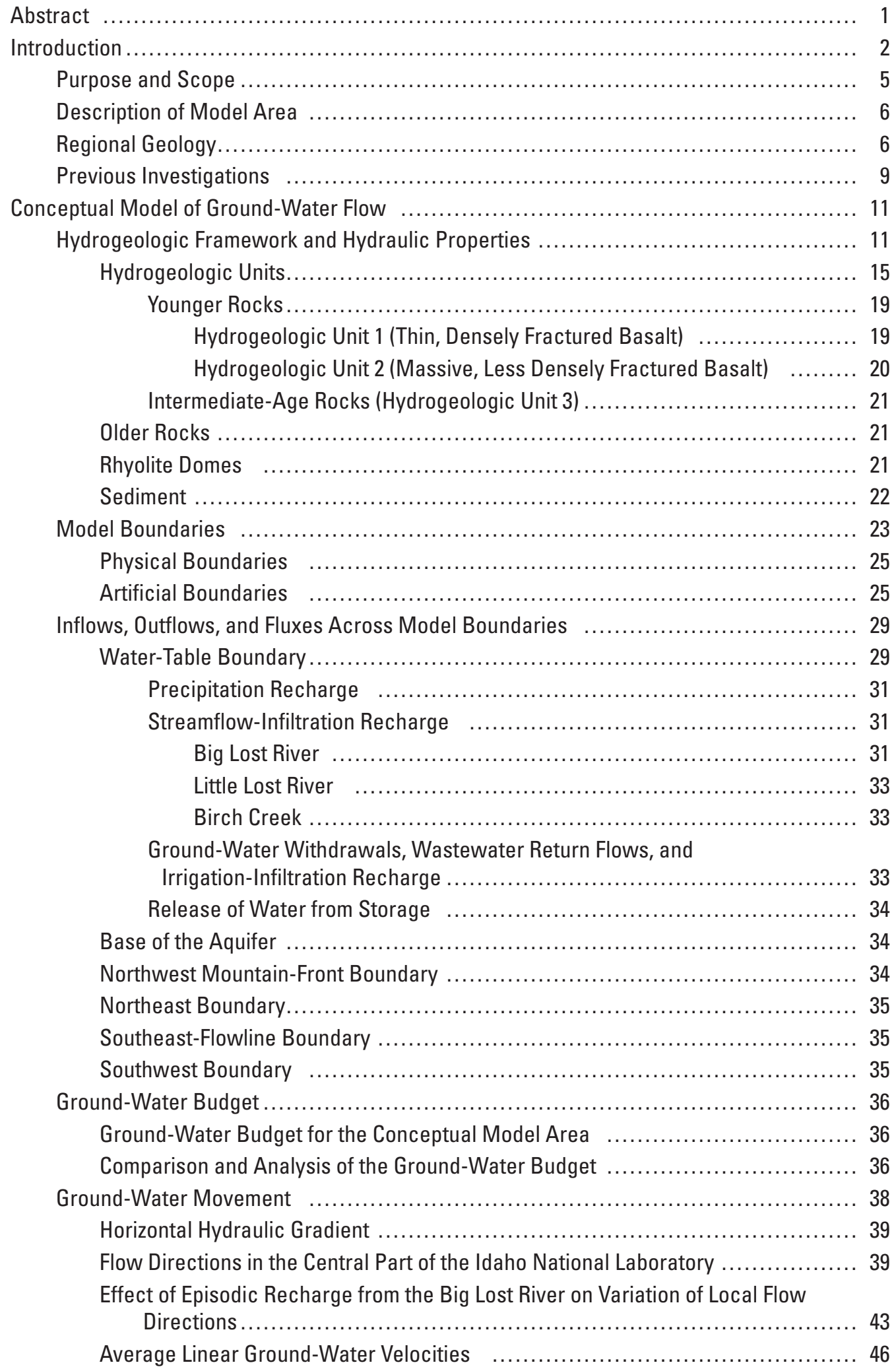




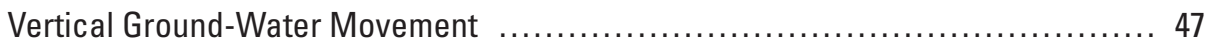

Model Representation of Features Affecting Ground-Water Flow ................... 47

Structural and Stratigraphic Controls on Ground-Water Flow .................. 47

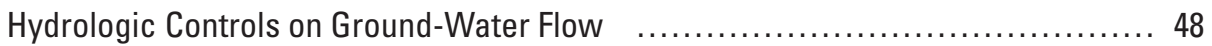

Representation of Ground-Water Flow Through the Model Area $\quad \ldots \ldots \ldots \ldots \ldots \ldots 48$

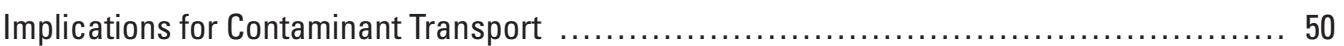

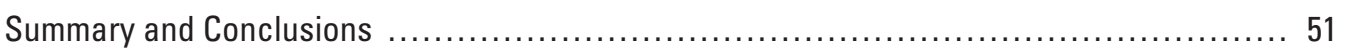

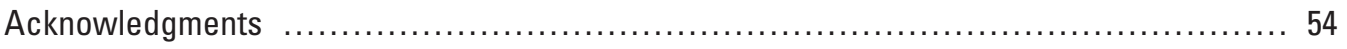

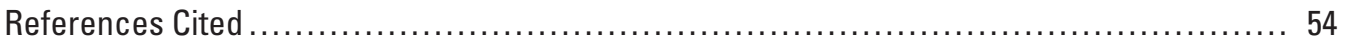

Appendix A. A Brief History of Wastewater-Disposal Practices at the Idaho National

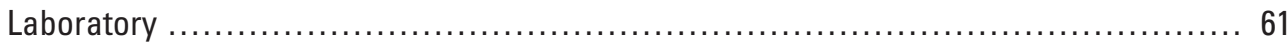

Appendix B. Levels of Information Needed for Constructing Conceptual Models at

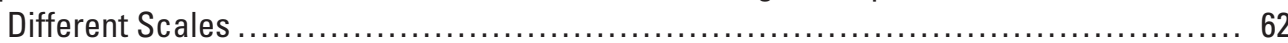

\section{Figures}

Figure 1. Map showing location of the Idaho National Laboratory, the model area, and selected facilities, wells, and streamflow-gaging stations....

Figure 2. Map showing distribution of selected waste contaminants in water from the eastern Snake River Plain aquifer, Idaho National Laboratory and vicinity,

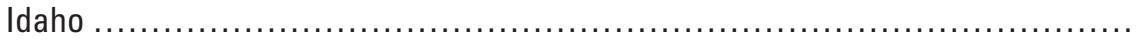

Figure 3. Map showing direction of regional ground-water flow, discharge areas, and irrigated acreage, eastern Snake River Plain, Idaho

Figure 4. Cross section and chart showing generalized geology, water-table altitude, and geologic groups and formations, and generalized stratigraphy of the eastern Snake River Plain, Idaho

Figure 5. Maps showing areas and grid sizes of ground-water models of the eastern Snake River Plain aquifer at the Idaho National Laboratory (INL) and vicinity, Idaho, relative to those of the Snake River Plain Regional Aquifer System Analysis (RASA) model

Figure 6. Cross sections showing composite stratigraphic units that form the eastern Snake River Plain aquifer, Idaho National Laboratory and vicinity, Idaho

Figure 7. Map showing approximate locations of volcanic rift zones and the axial volcanic high, Idaho National Laboratory and vicinity, Idaho

Figure 8. Map showing locations of volcanic vents and vent corridors, Idaho National Laboratory and vicinity, Idaho

Figure 9. Map showing distribution of hydrogeologic units present at the water table and water-table contours for 1980 in the model area, Idaho National Laboratory and vicinity, Idaho

Figure 10. Cross section showing distribution of hydrogeologic units along the direction of regional ground-water flow in the model area, Idaho National Laboratory and vicinity, Idaho

Figure 11. Chart showing correlation among stratigraphic units of the eastern Snake River Plain, composite stratigraphic units beneath the Idaho National Laboratory, and hydrogeologic units of the conceptual model, Idaho National Laboratory and vicinity, Idaho

Figure 12. Maps showing water-table contours, 1995, and areas of abundant sediment within the model area, Idaho National Laboratory and vicinity, Idaho 
Figure 13. Map and cross section showing location of the model boundaries, Idaho National Laboratory and vicinity, Idaho

Figure 14. Map showing depth to the base of the eastern Snake River Plain aquifer in the model area, Idaho National Laboratory and vicinity, Idaho

Figure 15. Relief map showing contact between the intermediate-age rocks of hydrogeologic unit 3 and the older rocks underlying the base of the eastern Snake River Plain aquifer beneath the model area, Idaho National Laboratory and vicinity, Idaho

Figure 16. Map showing Regional Aquifer System Analysis model grid used to approximate the northeast, southeast-flowline, and southwest boundaries of the conceptual model, Idaho National Laboratory and vicinity, Idaho

Figure 17. Map showing generalized ground-water budget components for the model area, 1980, Idaho National Laboratory and vicinity, Idaho

Figure 18. Hydrographs showing mean annual streamflow at selected streamflow-gaging stations on the Big Lost River, Idaho, for 1965-2002

Figure 19. Map showing distribution of lithium concentrations in water from wells in the eastern Snake River Plain aquifer, Idaho National Laboratory and vicinity, Idaho

Figure 20. Map showing average linear ground-water velocities and flow directions calculated from the assumed first arrivals of chlorine-36 or the tritium/helium-3- and chlorofluorocarbon-model ages of water from selected wells, Idaho National Laboratory and vicinity, Idaho

Figure 21. Map showing temperature of ground water in samples from wells, Idaho National Laboratory and vicinity, Idaho

Figure 22. Maps showing generalized water-level changes at the Idaho National Laboratory and vicinity, Idaho, for July 1981-July 1985, April-August 1988 to April-August 1991, March-May 1991 to March-May 1995, and March-May 1995 to March-May 1998

Figure 23. Hydrographs showing water levels in wells Arbor Test, USGS 9, USGS 12, and USGS 25 for 1948-2003, Idaho National Laboratory, Idaho

Figure 24. Cross section showing distribution of hydrogeologic units and the direction of ground-water flow for the model area, Idaho National Laboratory and vicinity, Idaho

\section{Tables}

Table 1. Summary of surface and subsurface wastewater disposal at selected facilities, Idaho National Laboratory, Idaho.

Table 2. Ranges of hydraulic conductivities and porosities for hydrogeologic units and other rocks of hydrogeologic importance, Idaho National Laboratory and vicinity, Idaho...

Table 3. Summary statistics of basalt flow thickness within individual hydrogeologic units, Idaho National Laboratory and vicinity, Idaho.

Table 4. Summary of conceptual model boundary characteristics and estimated 1980 inflows and outflows, Idaho National Laboratory and vicinity, Idaho.

Table 5. Summary of streamflow at two streamflow-gaging stations on the Big Lost River, Idaho

Table 6. Ground-water budget for the conceptual model area for 1980 and derived from the Regional Aquifer System Analysis (RASA) model of the Snake River Plain aquifer, Idaho 


\title{
Conversion Factors and Datums
}

\author{
Conversion Factors
}

\begin{tabular}{|c|c|c|}
\hline Multiply & By & To obtain \\
\hline acre & 4,047 & square meter $\left(\mathrm{m}^{2}\right)$ \\
\hline acre-foot (acre-ft) & 1,233 & cubic meter $\left(\mathrm{m}^{3}\right)$ \\
\hline cubic foot $\left(\mathrm{ft}^{3}\right)$ & 0.02832 & cubic meter $\left(\mathrm{m}^{3}\right)$ \\
\hline cubic foot per second $\left(\mathrm{ft}^{3} / \mathrm{s}\right)$ & 0.02832 & cubic meter per second $\left(\mathrm{m}^{3} / \mathrm{s}\right)$ \\
\hline cubic foot per day $\left(\mathrm{ft}^{3} / \mathrm{d}\right)$ & 0.02832 & cubic meter per day $\left(\mathrm{m}^{3} / \mathrm{d}\right)$ \\
\hline $\begin{array}{l}\text { cubic foot per second per square } \\
\text { mile }\left[\left(\mathrm{ft}^{3} / \mathrm{s}\right) / \mathrm{mi}^{2}\right]\end{array}$ & 0.01094 & $\begin{array}{l}\text { cubic meter per second per square } \\
\text { kilometer }\left[\left(\mathrm{m}^{3} / \mathrm{s}\right) / \mathrm{km}^{2}\right]\end{array}$ \\
\hline curie $(\mathrm{Ci})$ & 37,000 & megabecquerel $(\mathrm{MBq})$ \\
\hline foot $(\mathrm{ft})$ & 0.3048 & meter $(\mathrm{m})$ \\
\hline foot per mile (ft/mi) & 0.1894 & meter per kilometer $(\mathrm{m} / \mathrm{km})$ \\
\hline foot per day $(\mathrm{ft} / \mathrm{d})$ & .3048 & meter per day $(\mathrm{m} / \mathrm{d})$ \\
\hline foot per year $(\mathrm{ft} / \mathrm{yr})$ & .3048 & meter per year $(\mathrm{m} / \mathrm{yr})$ \\
\hline foot squared per day $\left(\mathrm{ft}^{2} / \mathrm{d}\right)$ & 0.09290 & meter squared per day $\left(\mathrm{m}^{2} / \mathrm{d}\right)$ \\
\hline gallon (gal) & 3.785 & liter $(\mathrm{L})$ \\
\hline gallon per minute (gal/min) & 0.06309 & liter per second $(\mathrm{L} / \mathrm{s})$ \\
\hline million gallons (Mgal) & 3,785 & cubic meter $\left(\mathrm{m}^{3}\right)$ \\
\hline inch per year (in/yr) & 25.4 & millimeter per year (mm/yr) \\
\hline mile (mi) & 1.609 & kilometer $(\mathrm{km})$ \\
\hline picocurie per liter (pCi/L) & 0.037 & becquerel per liter $(\mathrm{Bq} / \mathrm{L})$ \\
\hline square foot $\left(\mathrm{ft}^{2}\right)$ & 929.0 & square centimeter $\left(\mathrm{cm}^{2}\right)$ \\
\hline square foot $\left(\mathrm{ft}^{2}\right)$ & 0.09290 & square meter $\left(\mathrm{m}^{2}\right)$ \\
\hline square mile $\left(\mathrm{mi}^{2}\right)$ & 2.590 & square kilometer $\left(\mathrm{km}^{2}\right)$ \\
\hline
\end{tabular}

Temperature in degrees Celsius $\left({ }^{\circ} \mathrm{C}\right)$ may be converted to degrees Fahrenheit $\left({ }^{\circ} \mathrm{F}\right)$ as follows:

$$
{ }^{\circ} \mathrm{F}=\left(1.8 x^{\circ} \mathrm{C}\right)+32 .
$$

Transmissivity: The standard unit for transmissivity is cubic foot per day per square foot times feet of aquifer thickness [(ft $\left.\left.\mathrm{ft}^{3} / \mathrm{d}\right) / \mathrm{ft}^{2}\right] \mathrm{ft}$. In this report, the mathematically reduced form, foot squared per day $\left(\mathrm{ft}^{2} / \mathrm{d}\right)$, is used for convenience.

Specific conductance is given in microsiemens per centimeter at 25 degrees Celsius $(\mu \mathrm{S} / \mathrm{cm}$ at $\left.25^{\circ} \mathrm{C}\right)$.

Concentrations of chemical constituents in water are given either in milligrams per liter (mg/L) or micrograms per liter $(\mu \mathrm{g} / \mathrm{L})$.

Datums

Vertical coordinate information is referenced to the National Geodetic Vertical Datum of 1929 (NGVD 29).

Horizontal coordinate information is referenced to North American Datum of 1927 (NAD 27).

Altitude, as used in this report, refers to distance above the vertical datum. 


\title{
A Conceptual Model of Ground-Water Flow in the Eastern Snake River Plain Aquifer at the Idaho National Laboratory and Vicinity with Implications for Contaminant Transport
}

\author{
By Daniel J. Ackerman, Gordon W. Rattray, Joseph P. Rousseau, Linda C. Davis, and Brennon R. Orr
}

\section{Abstract}

Ground-water flow in the west-central part of the eastern Snake River Plain aquifer is described in a conceptual model that will be used in numerical simulations to evaluate contaminant transport at the Idaho National Laboratory (INL) and vicinity. The model encompasses an area of 1,940 square miles $\left(\mathrm{mi}^{2}\right)$ and includes most of the $890 \mathrm{mi}^{2}$ of the INL. A 50-year history of waste disposal associated with research activities at the INL has resulted in measurable concentrations of waste contaminants in the aquifer. A thorough understanding of the fate and movement of these contaminants in the subsurface is needed by the U.S. Department of Energy to minimize the effect that contaminated ground water may have on the region and to plan effectively for remediation.

Three hydrogeologic units were used to represent the complex stratigraphy of the aquifer in the model area. Collectively, these hydrogeologic units include at least 65 basalt-flow groups, 5 andesite-flow groups, and 61 sedimentary interbeds. Three rhyolite domes in the model area extend deep enough to penetrate the aquifer. The rhyolite domes are represented in the conceptual model as low permeability, vertical pluglike masses, and are not included as part of the three primary hydrogeologic units. Broad differences in lithology and large variations in hydraulic properties allowed the heterogeneous, anisotropic basalt-flow groups, andesite-flow groups, and sedimentary interbeds to be grouped into three hydrogeologic units that are conceptually homogeneous and anisotropic. Younger rocks, primarily thin, densely fractured basalt, compose hydrogeologic unit 1; younger rocks, primarily of massive, less densely fractured basalt, compose hydrogeologic unit 2; and intermediate-age rocks, primarily of slightly-to-moderately altered, fractured basalt, compose hydrogeologic unit 3. Differences in hydraulic properties among adjacent hydrogeologic units result in much of the large-scale heterogeneity and anisotropy of the aquifer in the model area, and differences in horizontal and vertical hydraulic conductivity in individual hydrogeologic units result in much of the small-scale heterogeneity and anisotropy of the aquifer in the model area.
The inferred three-dimensional geometry of the aquifer in the model area is very irregular. Its thickness generally increases from north to south and from west to east and is greatest south of the INL. The interpreted distribution of older rocks that underlie the aquifer indicates large changes in saturated thickness across the model area.

The boundaries of the model include physical and artificial boundaries, and ground-water flows across the boundaries may be temporally constant or variable and spatially uniform or nonuniform. Physical boundaries include the water-table boundary, base of the aquifer, and northwest mountain-front boundary. Artificial boundaries include the northeast boundary, southeast-flowline boundary, and southwest boundary. Water flows into the model area as (1) underflow $\left(1,225\right.$ cubic feet per second $\left.\left(\mathrm{ft}^{3} / \mathrm{s}\right)\right)$ from the regional aquifer (northeast boundary-constant and nonuniform), (2) underflow $\left(695 \mathrm{ft}^{3} / \mathrm{s}\right)$ from the tributary valleys and mountain fronts (northwest boundary-constant and nonuniform), (3) precipitation recharge $\left(70 \mathrm{ft}^{3} / \mathrm{s}\right)$ (constant and uniform), streamflow-infiltration recharge $\left(95 \mathrm{ft}^{3} / \mathrm{s}\right)$ (variable and nonuniform), wastewater return flows (6 $\mathrm{ft}^{3} / \mathrm{s}$ ) (variable and nonuniform), and irrigation-infiltration recharge $\left(24 \mathrm{ft}^{3} / \mathrm{s}\right)$ (variable and nonuniform) across the water table (water-table boundary-variable and nonuniform), and (4) upward flow across the base of the aquifer $\left(44 \mathrm{ft}^{3} / \mathrm{s}\right)$ (uniform and constant). The southeast-flowline boundary is represented as a no-flow boundary. Water flows out of the model area as underflow $\left(2,037 \mathrm{ft}^{3} / \mathrm{s}\right)$ to the regional aquifer (southwest boundary_-variable and nonuniform) and as ground-water withdrawals $\left(45 \mathrm{ft}^{3} / \mathrm{s}\right.$ ) (water table boundaryvariable and nonuniform).

Ground-water flow increases progressively in a direction downgradient of the northeast boundary. This increased flow is the result of tributary-valley and mountain-front underflows along the northwest boundary and precipitation recharge and streamflow-infiltration recharge across the water-table boundary. Ground water flows in all three hydrogeologic units beneath the INL. South of the INL, the younger rocks, hydrogeologic units 1 and 2, are either not present or are above the water table and all flow occurs through the intermediateage rocks, hydrogeologic unit 3. 
The direction of regional ground-water flow is from northeast to southwest. Flow directions beneath the INL vary locally from southeast to southwest and fluctuate in response to episodic recharge from streamflow infiltration. Water-table gradients immediately upgradient of the northeast boundary are 27 to 60 feet per mile (ft/mi); and southwest of the INL gradients are 4 to $30 \mathrm{ft} / \mathrm{mi}$. Beneath the INL gradients are much flatter, 1 to $8 \mathrm{ft} / \mathrm{mi}$, and precise definition of flow direction is difficult to determine.

Long-term monitoring of contaminant movement in the aquifer at the INL indicates that ground-water velocities in the thin, fractured basalts of hydrogeologic unit 1, the uppermost hydrogeologic unit of the aquifer, range from 4 to 20 feet per day (ft/d) south of the Test Reactor Area and the Idaho Nuclear Technology and Engineering Center. These velocities probably indicate preferential flow along the many interflow zones of the thin, fractured basalt flows composing the uppermost hydrogeologic unit. Hydraulic conductivities (500 to $5,000 \mathrm{ft} / \mathrm{d}$ ) estimated from velocity measurements were consistent with those derived from aquifer tests conducted in this hydrogeologic unit. Almost two-thirds of the hydraulic conductivities derived from aquifer-test measurements in hydrogeologic unit 1 were larger than $100 \mathrm{ft} / \mathrm{d}$ and about one-third were larger than 1,000 ft/d.

Most contaminant movement beneath the INL probably takes place in the thin, densely fractured, and highly conductive basalts and interbedded sediments of hydrogeologic unit 1, which compose most of the upper $200 \mathrm{ft}$ of the aquifer beneath most of the INL. This hypothesis is based on interpretation of a generalized northeast-to-southwest cross section of ground-water flow across the model area that depicts the effects of the hydrogeologic framework on flow in each of the hydrogeologic units used to represent the aquifer. This interpretation indicates that head decreases and then increases with depth with thickening and thinning of the aquifer in a direction downgradient of the northeast boundary. Beneath the INL, the smaller conductivity of the massive, less densely fractured basalts and interbedded sediments of hydrogeologic unit 2 restricts the downward movement of contaminants from hydrogeologic unit 1 . The largest changes in water-table gradients are upgradient of where the massive basalts of hydrogeologic unit 2 are inferred to intersect the water table south of the INL. Water probably flows downward through hydrogeologic unit 2 into hydrogeologic unit 3 at this location, implying deeper circulation of contaminants that migrate offsite.

Features of the conceptual model that most affect interpretations of contaminant transport are (1) implicit representation of infiltration recharge through the unsaturated zone, (2) preferential flow along highly conductive interflow zones, primarily in the thin, densely fractured basalts of hydrogeologic unit 1, implying large horizontal to vertical anisotropy, (3) restricted downward movement of flow and contaminants in hydrogeologic unit 1 into the less conductive basalts of hydrogeologic unit 2 beneath the INL, (4) the inferred downward movement and deeper circulation of water upgradient of where the massive, less densely fractured basalt of hydrogeologic unit 2 intersects the water table southwest of the INL, and (5) enhanced dispersion of contaminants resulting from the spatial and temporal variability of streamflow-infiltration recharge that is in close proximity to contaminated ground water.

\section{Introduction}

The Idaho National Laboratory (INL), established in 1949, occupies about $890 \mathrm{mi}^{2}$ of the eastern Snake River Plain (SRP) in southeastern Idaho (fig. 1). The INL was established to build, operate, and test nuclear reactors. The scope of work at the INL increased during the 1950s to include other nuclearresearch programs, the reprocessing of spent nuclear fuel, and the storage and disposal of radioactive and chemical waste.

The INL overlies the west-central part of the eastern SRP aquifer, which is a major source of water for agricultural, industrial, and domestic uses in southeastern Idaho.

Radioactive and chemical wastes were discharged to the unsaturated zone and aquifer at the INL for over 50 years and several waste contaminants are present in the aquifer (fig. 2) at concentrations that exceed U.S. Environmental Protection Agency maximum contaminant levels (MCLs) for drinking water (table 1). The principal sources of contaminants are wastewater-disposal sites at Test Area North (TAN), the Test Reactor Area (TRA), and the Idaho Nuclear Technology and Engineering Center (INTEC). Wastewater-disposal sites have included lined evaporation ponds, unlined infiltration ponds and ditches, drain fields, and injection wells. Wastes buried in shallow pits and trenches at the Radioactive Waste Management Complex (RWMC) also are sources of contaminants in ground water. Appendix A (at back of report) contains a brief history of wastewater-disposal practices at the INL.

The presence of contaminants in the eastern SRP aquifer has led to public concern about the quality of water in the aquifer and the effect that contaminated ground water may have on the region. To respond to this concern a thorough understanding of the fate and movement of contaminants in the subsurface is needed. The U.S. Geological Survey (USGS) in cooperation with the U.S. Department of Energy (DOE) is developing a three-dimensional numerical model of groundwater flow and contaminant transport in the aquifer at the INL and vicinity. The model will assist the DOE to minimize the effect that subsurface contaminants may have on the region and to plan effectively for remediation. Ground-water flow and contaminant transport in the aquifer beneath the INL were modeled previously by Robertson (1974) and Goode and Konikow (1990b). The new calibrated, numerical flow-andtransport model will build on the work of these earlier models and will be based on a refined conceptual model of flow beneath the INL presented in this report. New information available for developing the current flow-and-transport model 


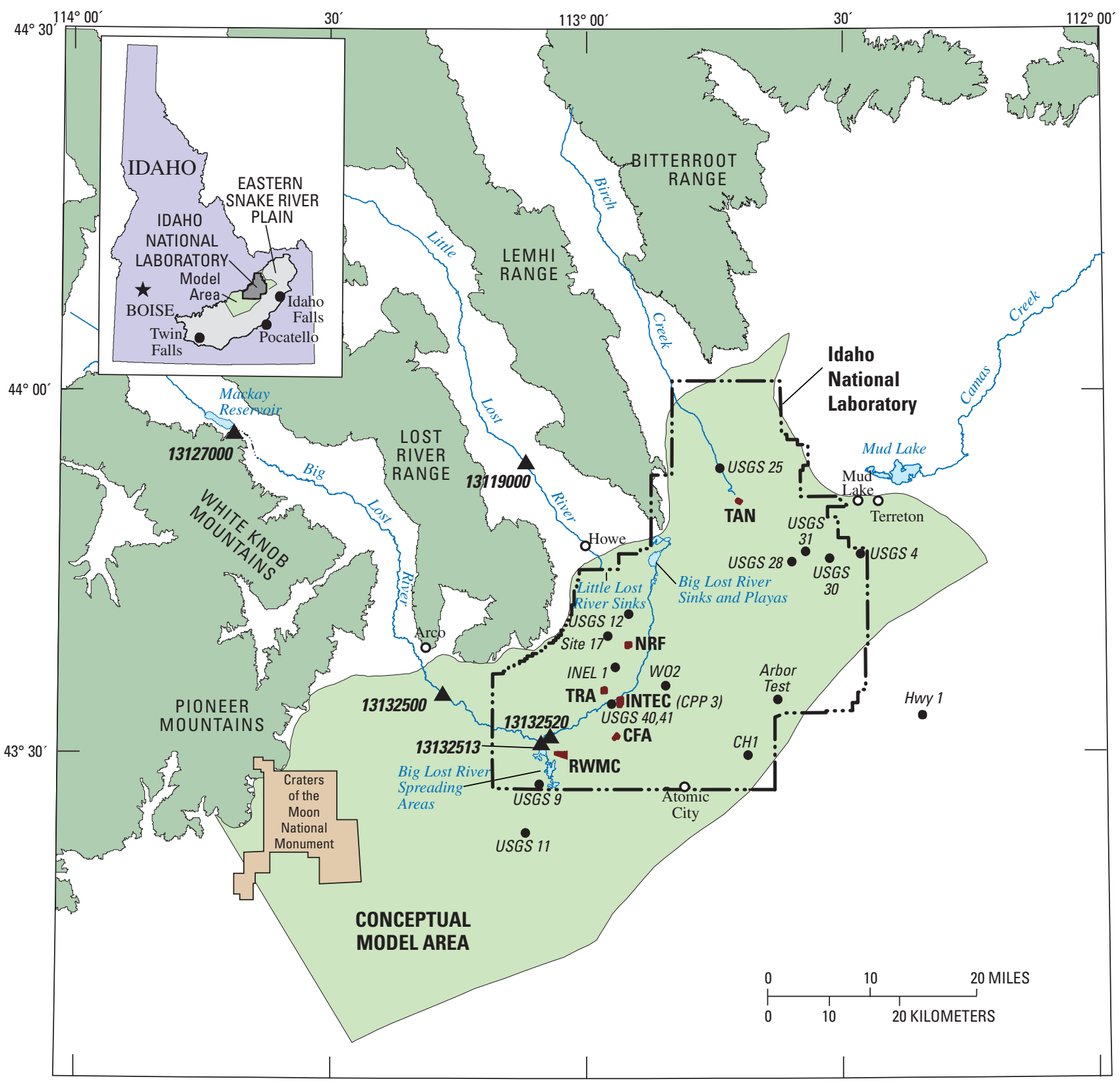

Base from U.S. Geological Survey digital data, 1:24,000 and 1:100,000

Universal Transverse Mercator projection, Zone 12

Datum is North American Datum of 1927

\section{EXPLANATION}

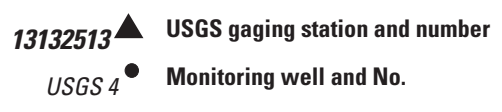

- Selected facilities at the Idaho National Laboratory

CFA Central Facilities Area

INTEC Idaho Nuclear Technology and Engineering Center

NRF Naval Reactors Facility
RWMC Radioactive Waste Management Complex

TAN Test Area North

TRA Test Reactor Area

Figure 1. Location of the Idaho National Laboratory, the model area, and selected facilities, wells, and streamflow-gaging stations. 


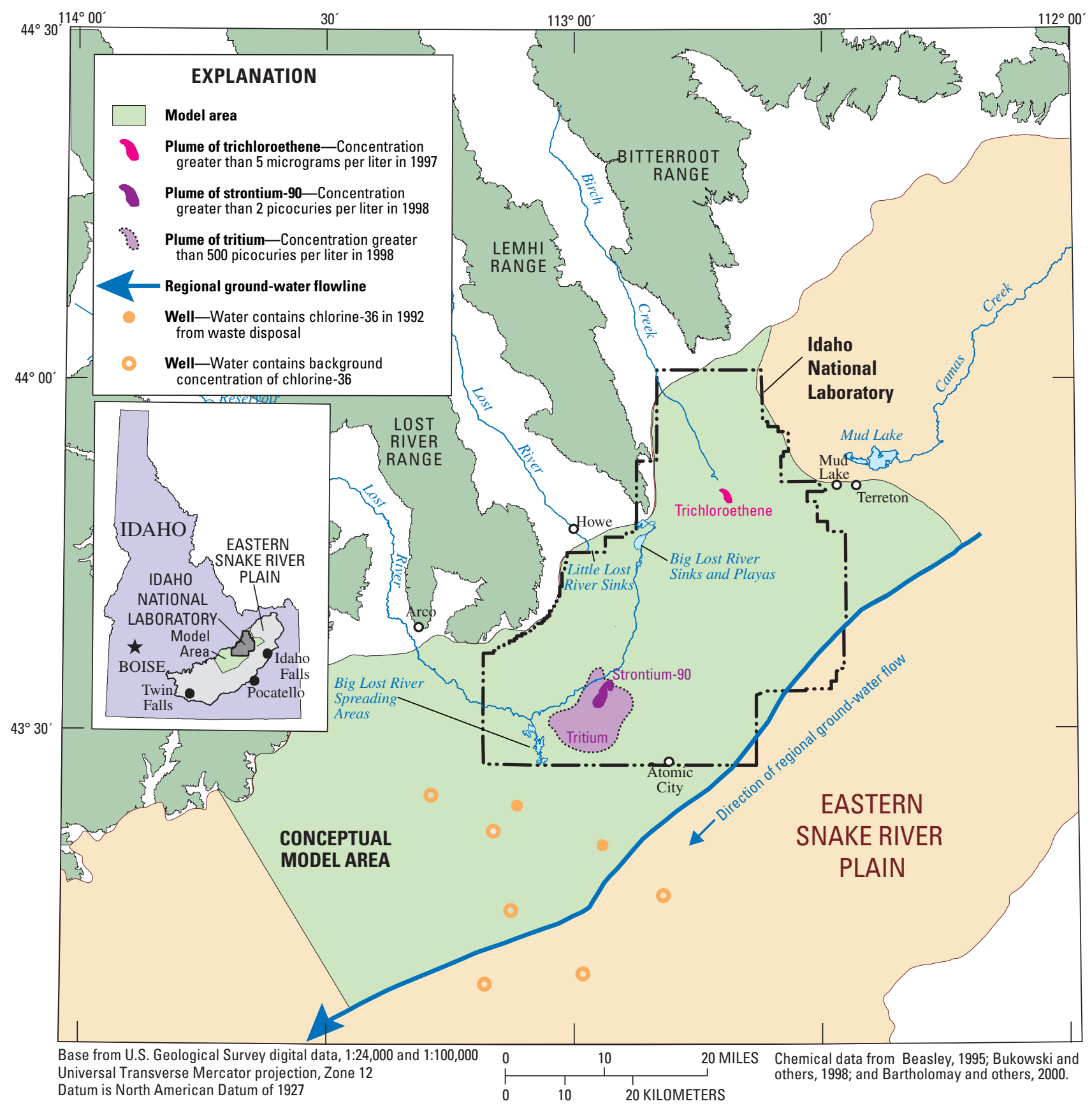

Figure 2. Distribution of selected waste contaminants in water from the eastern Snake River Plain aquifer, Idaho National Laboratory and vicinity, Idaho.

includes (1) an increased understanding of the hydrogeology beneath the INL, (2) an increased understanding of the amount and timing of transient recharge to the aquifer beneath the INL (including a near record amount of streamflow infiltration from the Big Lost River in 1983 and 1984 and a period with little or no infiltration between 1987 and 1994), (3) additional information about the amount and timing of wastewater disposal, (4) more than 30 years of additional water-level data for numerical-model calibration, and (5) more than 30 years of additional measurements of contaminant concentrations in the aquifer. This additional information will allow a new flow-and-transport model to be developed using more accurate estimates of hydrogeologic properties, such as hydraulic conductivity, storativity, and effective porosity and to be calibrated over a longer simulated period than that of the previous flow-and-transport models. 
Table 1. Summary of surface and subsurface wastewater disposal at selected facilities, Idaho National Laboratory, Idaho.

[Estimated disposal quantities: Estimated disposal quantities for Test Area North, Test Reactor Area, and Idaho Nuclear Technology and Engineering Center from French and others (1999). Estimated disposal quantities for the Radioactive Waste Management Complex from Mann and Knobel (1987) and Becker and others (1998). Contaminant concentrations from Mann and Beasley (1994), Bukowski and others (1998), and Bartholomay and others (2000). Abbreviations: MCLs, U.S. Environmental Protection Agency maximum contaminant levels for drinking water; Ci, curies; ${ }^{137} \mathrm{Cs}$, cesium-137; ${ }^{3} \mathrm{H}$, tritium; ${ }^{90} \mathrm{Sr}$, strontium-90; TCE, trichloroethene; PCE, tetrachloroethene; DCE, cis- and trans-1,2-dichloroethene; Cr, chromium, ${ }^{129} \mathrm{I}$, iodine-129; $\mathrm{CCl}_{4}$, carbon tetrachloride; gal, gallon]

\begin{tabular}{lcccc}
\hline \multicolumn{1}{c}{ Facility } & \multicolumn{1}{c}{$\begin{array}{c}\text { Disposal } \\
\text { site }\end{array}$} & Years of disposal & $\begin{array}{c}\text { Estimated disposal } \\
\text { quantities }\end{array}$ & $\begin{array}{c}\text { Contaminants with concentrations } \\
\text { exceeding MCLs in ground water }\end{array}$ \\
\hline Test Area North & Well, pond & 1953 to 1993 & $\begin{array}{c}61 \mathrm{Ci} \\
717 \text { million gal }\end{array}$ & ${ }^{137} \mathrm{Cs},{ }^{3} \mathrm{H},{ }^{90} \mathrm{Sr}, \mathrm{TCE}, \mathrm{PCE}, \mathrm{DCE}$ \\
& Well, ponds & 1952 to present & $\begin{array}{c}53,879 \mathrm{Ci} \\
5,180 \text { million gal }\end{array}$ & ${ }^{3} \mathrm{H}, \mathrm{Cr}$ \\
Test Reactor Area & Well, ponds & 1952 to present & $22,254 \mathrm{Ci}$ & ${ }^{3} \mathrm{H},{ }^{90} \mathrm{Sr},{ }^{129} \mathrm{I}$ \\
Idaho Nuclear Technology and & & 19,165 million gal & \\
$\quad \begin{array}{l}\text { Engineering Center } \\
\text { Radioactive Waste Management } \\
\text { Complex }\end{array}$ & $\begin{array}{c}\text { Excavation } \\
\text { pits, }\end{array}$ & 1952 to present & $1,532,600 \mathrm{Ci}$ & $\mathrm{CCl}_{4}$ \\
& trenches & & 0.09 million gal & \\
\hline
\end{tabular}

\section{Purpose and Scope}

This report describes a conceptual model of ground-water flow in the west-central part of the eastern SRP aquifer that will be used in numerical simulations to evaluate contaminant transport at the INL and vicinity. This part of the aquifer contains contaminants that were discharged to the subsurface at facilities located at the INL. The conceptual model was developed to provide a qualitative description of ground-water flow at the INL and vicinity so that hydrogeologic features most strongly affecting contaminant movement could be identified. The model integrates the current understanding of the stratigraphy, hydraulic properties of the rocks, hydrology, and ground-water movement in the model area.

The model area $\left(1,940 \mathrm{mi}^{2}\right)$ is subregional in scale, and is intermediate in scale between the regional-scale model of the eastern SRP aquifer $\left(10,800 \mathrm{mi}^{2}\right)$, described in reports of the Regional Aquifer System Analysis (RASA) study of the aquifer, and local-scale models of the aquifer at INL facilities (less than about $10 \mathrm{mi}^{2}$ ) (Schafer-Perini, 1993; Magnuson and Sondrup, 1998). The conceptual models for the three scales include the same basic information but at different levels of detail (Appendix B, at back of report). For example, at many INL facilities data are sufficient to represent the heterogeneity and anisotropy of the aquifer at the scale of individual basalt flows or basalt-flow groups. In the current subregional-scale model, however, data are not sufficient to resolve individual basalt flows and basalt-flow groups and these were grouped with other basalt flows having similar hydraulic characteristics into homogenous and anisotropic hydrogeologic units.

Data used for developing the conceptual model were obtained from numerous reports published during the past
50 years, including ground-water modeling studies, reports generated for the eastern SRP regional aquifer system as part of the USGS RASA study, and several recent studies. These data, which include petrologic, stratigraphic, geophysical, geochemical, hydraulic-property, and hydrologic data were acquired primarily from (1) surficial mapping, (2) analyses of numerous outcrops and hundreds of core samples, (3) aquifer tests, (4) borehole geophysical logs and surface geophysical surveys, (5) more than 50 years of water-level measurements and water-chemistry analyses from more than three hundred wells, and (6) long-term records of streamflow (100 years) and wastewater discharge to the aquifer (34 years).

Although a large quantity of data were available for developing the conceptual model, there were several limitations with these data. These data limitations included (1) uneven spatial distribution, both areally and vertically [for example, of the 333 boreholes used in this study to define the hydrogeologic framework, 300 are within the boundaries of the INL, mostly in and near INL facilities (Anderson and others, 1997, figs. 2 to 5 , table 1)], (2) scaling-compatibility issues involving the application of small-scale measurements to a large-scale study (for example, the use of core-scale measurements to define large-scale hydraulic properties), (3) uncertainties arising from partial borehole penetrations and different borehole completions that complicate interpretations of water-level, water-chemistry, and hydraulic-conductivity measurements (for example, of the 114 monitoring wells that were used to estimate hydraulic conductivity only 13 of these penetrate more than $300 \mathrm{ft}$ into the aquifer), and (4) discontinuous or nonexistent hydrologic records (for example, streamflow records for Little Lost River and Birch Creek streamflow onto the INL). 


\section{Description of Model Area}

The model area extends $75 \mathrm{mi}$ from northeast to southwest and $35 \mathrm{mi}$ from northwest to southeast and includes most of the INL (fig. 2). The model area is bounded on the northwest by mountain fronts and valleys tributary to the plain and on the southeast by an inferred regional groundwater flowline. The northeast boundary is defined by a steep increase in hydraulic gradient. The southwest boundary is $25 \mathrm{mi}$ downgradient of the southwestern extent of measured concentrations of INL-derived contaminants in the aquifer (Beasley, 1995, appendix 2). The vertical dimension of the model area is represented by the saturated thickness of the aquifer, which is estimated to range from less than $600 \mathrm{ft}$ to more than $3,000 \mathrm{ft}$.

The model area is contained in the eastern SRP, which is a relatively flat topographic depression, about 200-mi long and 50- to 70-mi wide, surrounded by mountains on three sides. The altitude of the plain ranges from about $2,900 \mathrm{ft}$ near King Hill to about 6,200 ft near the southwestern extent of the Yellowstone Plateau (fig. 3), and the surrounding mountains reach altitudes of 12,000 ft. The surface of the plain is primarily loess and olivine basalt and contains volcanic landforms, such as cinder and lava cones, shield volcanoes, rhyolite domes that rise as much as $2,500 \mathrm{ft}$ above the plain, sand dunes, and a canyon carved by the Snake River that ranges from 50- to 550-ft deep (Lindholm, 1996, p. 5).

Climate in the model area is semiarid and mean annual precipitation at the INL is about $0.7 \mathrm{ft}$ (Clawson and others, 1989, tables D-1 and D-2; Goodell, 1988, fig. 5). About 0.1 to $0.3 \mathrm{ft}$ of snow usually accumulates at the INL during winter and snowmelt and runoff from the adjacent mountains, typically in late spring and early summer, produce peak streamflow. Mean annual air temperature at the Central Facilities Area (CFA) at the INL between 1950 and 1988 was $30^{\circ} \mathrm{F}$ and the coldest and warmest mean monthly temperatures were measured in January and during July-August, respectively (Clawson and others, 1989, table B-3).

Ground water in the eastern SRP aquifer flows to the southwest and discharges principally through large springs and seeps along the Snake River in the Thousand Springs area in the southwestern part of the plain (fig. 3). Recharge to the eastern SRP aquifer is from infiltration of precipitation, underflow from tributary drainages, infiltration of surface water diverted for irrigation, and stream and canal losses (Garabedian, 1992, p. 11). Land irrigated with ground water on the eastern SRP is located along the southeastern and southern margins of the plain, from north of Idaho Falls to west of Twin Falls, and in the Mud Lake area northeast of the INL (fig. 3). In 1980, about 1,760,000 acre-ft of ground water was withdrawn from about 4,000 wells across the plain to irrigate about 930,000 acres (Garabedian, 1992, p. 19-21). Intermittent streamflow onto the plain near the model area is from Camas Creek, Birch Creek, Little Lost River, and Big Lost River (fig. 1).

\section{Regional Geology}

The eastern SRP was formed by the migration of the North American Continental Plate westward across a mantleplume hot spot (Pierce and Morgan, 1992, p. 2). The plain is underlain by a 1,000 - to 2,000 - $\mathrm{ft}$ thick-layered sequence of Quaternary basalt flows and sediment interbeds overlying a several-thousand-feet thick sequence of Quaternary and late Tertiary volcanic rocks (fig. 4) (Whitehead, 1992, pl. 3). Major Quaternary and late Tertiary stratigraphic units in the eastern SRP are the: (1) Snake River Group $(\mathrm{Qb})$, which is the most extensive rock unit in the eastern SRP and contains mainly olivine basalt and sedimentary rocks; (2) Yellowstone Group and Plateau Rhyolite (Qsv), containing silicic volcanic rocks; (3) upper part of the Idaho Group (includes the Bruneau and Glenns Ferry Formations), containing mainly olivine basalt (QTb) and sedimentary rocks (QTs); (4) Walcott Tuff, Starlight Formation, and Salt Lake Formation (QTs), containing mainly sedimentary rocks, basalt, and tuff; (5) lower part of the Idaho Group (Tb, includes the Banbury Basalt), containing mainly flood-type basalts, silicic rocks, and sediment; and (6) Idavada Volcanics (Tsv), containing silicic volcanic rocks and sediment. Sedimentary units include flood plain and glacial deposits $(\mathrm{Qa})$, windblown deposits $(\mathrm{Qw})$, and lake deposits and tuffaceous sedimentary rocks (QTs) (Whitehead, 1992, pl. 1).

Several volcanic landforms define the structure and topography of the eastern Snake River Plain. An axial volcanic high and volcanic rift zones trend parallel and perpendicular to the long axis of the plain, respectively. The rift zones appear to be extensions of the adjacent Basin and Range structures (Kuntz and others, 1992, 1994; Anderson and Liszewski, 1997). Volcanic vents and fissures are concentrated along the axial volcanic high and volcanic rift zones (Anderson and others, 1999, p. 13, fig. 7; Hughes and others, 1999, p. 145), and are major sources of basaltic rocks on the plain. Rhyolite domes also are concentrated within the axial volcanic high. Topographic depressions in areas defined by elevated volcanic topography, such as the axial volcanic high and volcanic rift zones, are areas where abundant sediment accumulated during recent times (Bestland and others, 2002, fig. 1; Geslin and others, 2002, p. 12-13, fig. 1). 


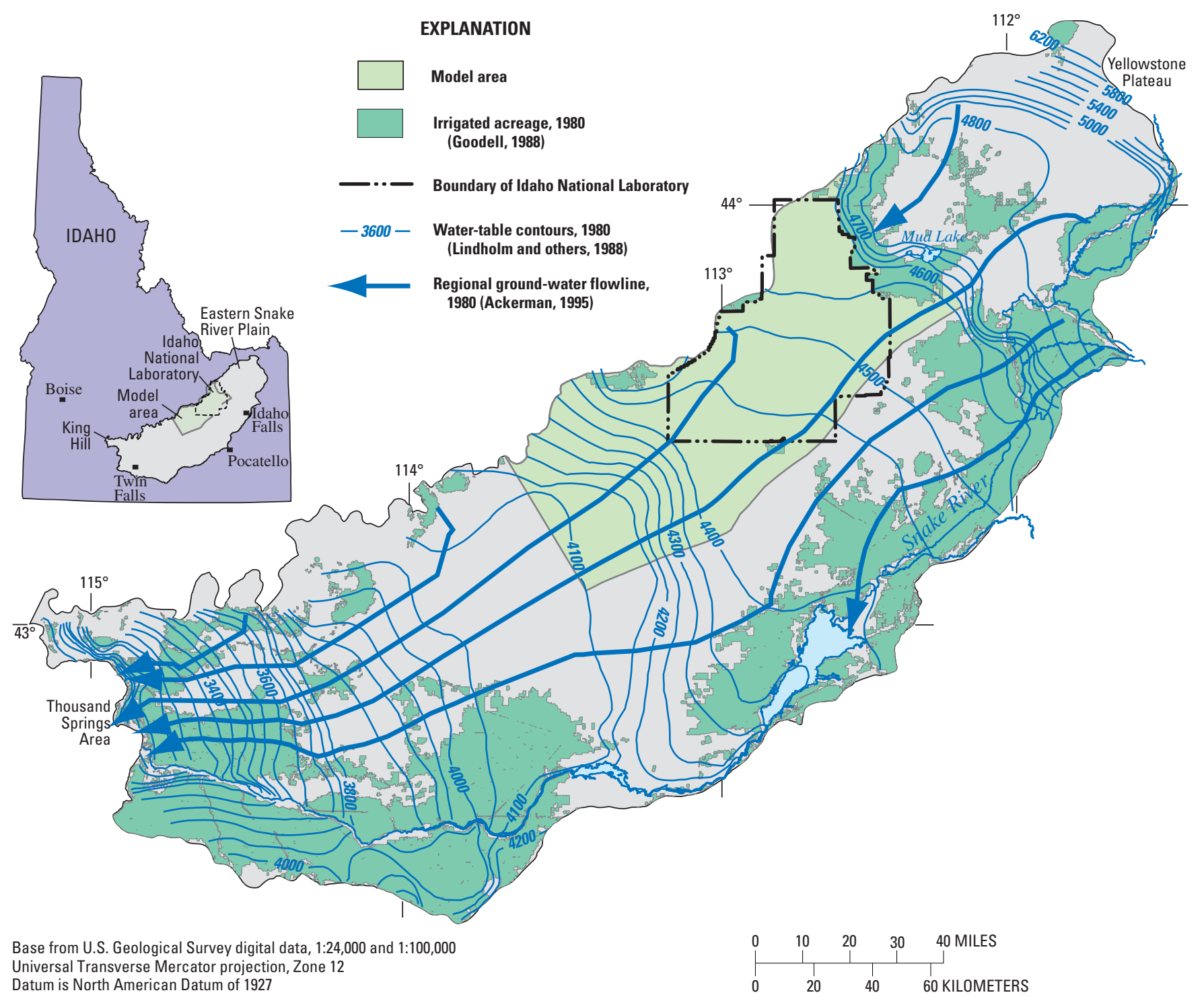

Figure 3. Direction of regional ground-water flow, discharge areas, and irrigated acreage, eastern Snake River Plain, Idaho. 

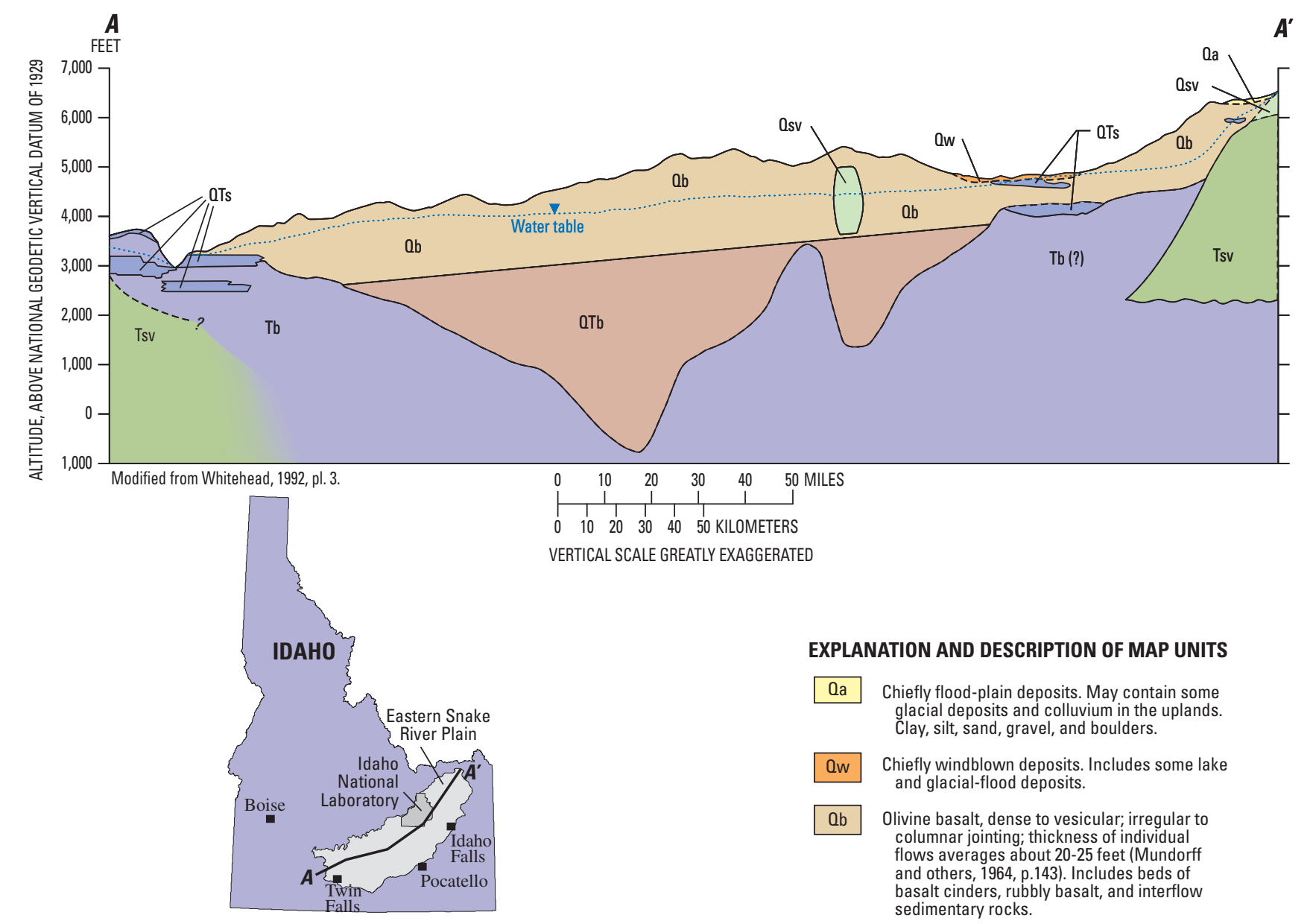

EXPLANATION AND DESCRIPTION OF MAP UNITS

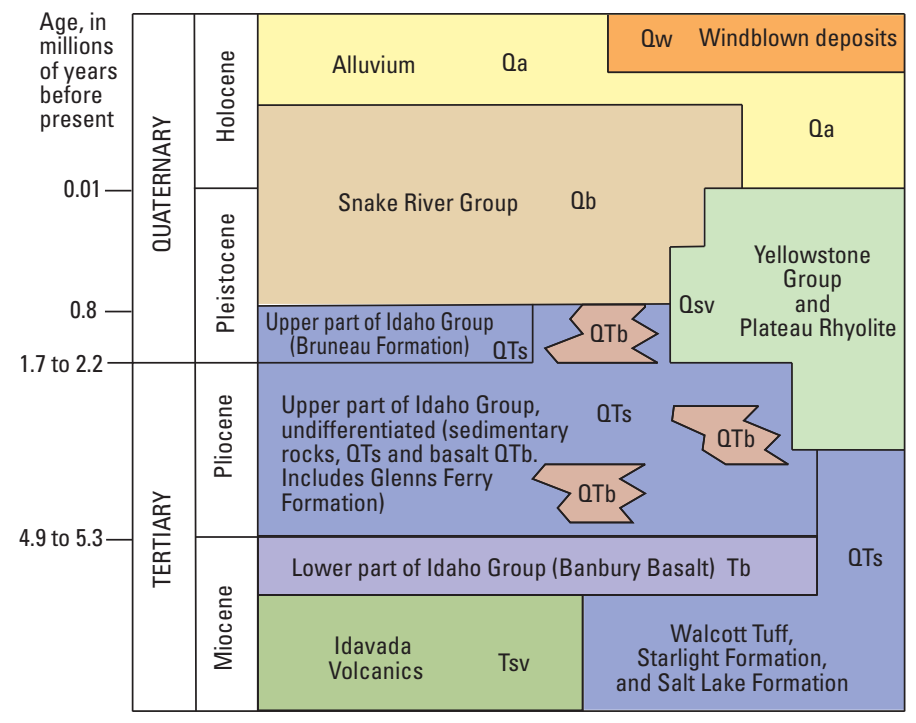 Oa Chiefly flood-plain deposits. May contain some
glacial deposits and colluvium in the uplands. Clay, silt, sand, gravel, and boulders.
Qw Chiefly windblown deposits. Includes some lake and glacial-flood deposits.
$\mathrm{Qb}$ Olivine basalt, dense to vesicular; irregular to columnar jointing; thickness of individual flows averages about 20-25 feet (Mundorff and others, 1964, p.143). Includes beds of basalt cinders, rubbly basalt, and interflow sedimentary rocks.
Qsv Rhyolitic ash-flow tuff, occurs as thick flows and blankets of welded tuff with associated fine- to coarse-grained ash and pumice beds.
QTb Olivine basalt similar to Qb above.
QTs Subaerial and lake deposits of clay, silt, sand, and gravel. Compacted to poorly consolidated.
Tb Flood-type basalt, dense; columnar jointing in many places. May include some rhyolitic and andesitic rocks. Queried where uncertain.
Tsv Rhyolitic, latitic, and andesitic rocks, massive and dense.

Modified from Whitehead, 1992, pl. 1.

Figure 4. Generalized geology, water-table altitude, and geologic groups and formations, and generalized stratigraphy of the eastern Snake River Plain, Idaho. 


\section{Previous Investigations}

The most complete and systematic study of the eastern SRP aquifer was conducted as part of the Regional Aquifer System Analysis (RASA) program. In this study, Whitehead (1992) provided an extensive description of the regional hydrogeologic framework, hydrologic properties, and geologic controls on ground-water movement. Kjelstrom (1995) described streamflow gains and losses and compiled regional ground-water budgets. Garabedian (1992) synthesized hydrologic data and constructed a regional ground-water flow model (fig. 5). These studies provide the regional context for describing flow in the model area.

Information from several previous studies was used to construct the conceptual model. Anderson and Liszewski (1997) combined information from geophysical logs, rock cores, and outcrops to describe the stratigraphy of the unsaturated zone and aquifer beneath the INL. This study provided the basis for determining the hydrogeologic units of the eastern SRP aquifer at the INL. Ackerman (1991) and Anderson and others (1999) described the distribution of hydraulic properties in the eastern SRP aquifer and the geologic features that control that distribution. Bennett (1990) estimated the amount, distribution, and timing of recharge to the eastern SRP aquifer at the INL from the infiltration of streamflow from the Big Lost River.

Previous ground-water models also provided information used to construct the conceptual model. Spinazola (1994) simulated ground-water flow in the Mud Lake area upgradient of the INL (fig. 5). Ackerman (1995) developed a regional ground-water flow and advective-transport model based on studies by Garabedian (1992). Pathline simulations from Ackerman's (1995) model provide a basis for description of ground-water flow near the INL. McCarthy and others (1995) developed a ground-water flow model for the area of the INL to support ground-water remediation for specific INL facilities (fig. 5).
The current modeling effort builds on the groundwater flow and contaminant transport modeling results of Robertson (1974) and Goode and Konikow (1990b). Robertson (1974) simulated two-dimensional steady-state and transient ground-water flow and contaminant transport. The simulations successfully reproduced the unusually wide contaminant plumes present in the upper $200 \mathrm{ft}$ of the aquifer; however, to do so required a larger transverse $\left(\alpha_{\mathrm{T}}=450 \mathrm{ft}\right)$ than longitudinal ( $\alpha_{L}=300 \mathrm{ft}$ ) dispersivity. These values for dispersivity were derived using a steady-state flow model and no recharge from the Big Lost River (Goode and Konikow, 1990b, p. 417); no values for dispersivity were reported for the transient flow simulations. The $\alpha_{\mathrm{L} /} \alpha_{\mathrm{T}}$ ratio derived from this model, 0.67 , is smaller than the ratios of 24 other published pairs of $\alpha_{\mathrm{L} /} \alpha_{\mathrm{T}}$; the other $\alpha_{\mathrm{L} /} \alpha_{\mathrm{T}}$ ratios ranged from 1 to 53 with a mean of 8.8 (Gelhar and others, 1992, table 1). This small $\alpha_{\mathrm{L} /}$ $\alpha_{T}$ ratio, and the large simulated values for $\alpha_{L}$ and $\alpha_{T}$, indicated that some geologic and hydrologic features of the aquifer that were important for modeling contaminant transport were not represented in Robertson's (1974) model.

Goode and Konikow (1990b) recognized that groundwater flow directions and velocities varied temporally in the shallow flow field near contaminated ground water at the INL, and that the large model-derived $\alpha_{\mathrm{T}}$ of Robertson (1974) could have included these fluctuations. If transient variations in the flowfield are ignored or unknown, then larger estimates for $\alpha_{T}$ and smaller $\alpha_{L} \alpha_{T}$ ratios may be required to account for the temporally-variable directions of advective flow. Using Robertson's (1974) steady-state and transient models, but modifying the simulated magnitude, timing, and spatial distribution of recharge from the Big Lost River, Goode and Konikow (1990b) evaluated the effect of transient ground-water flow at the INL on estimates of longitudinal and transverse dispersivity. Although Goode and Konikow's (1990b) simulations resulted in $\alpha_{\mathrm{T}}$ values that were smaller than values for $\alpha_{L}$, their results were inconclusive and they were unable to determine the effect that transient variations in the flow field had on dispersivities. 
Snake River Plain Regional Aquifer System Analysis (RASA) (Garabedian, 1992)
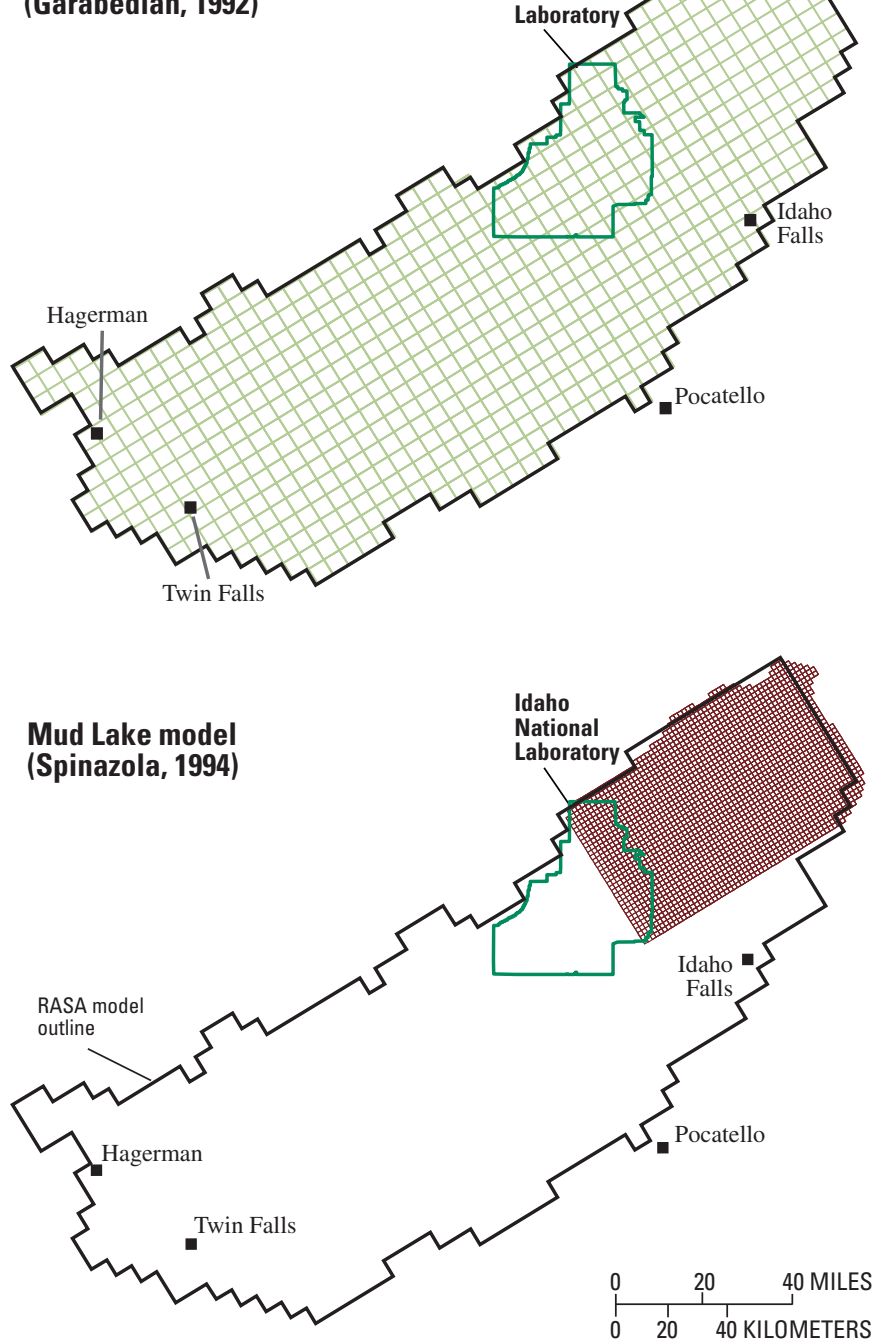
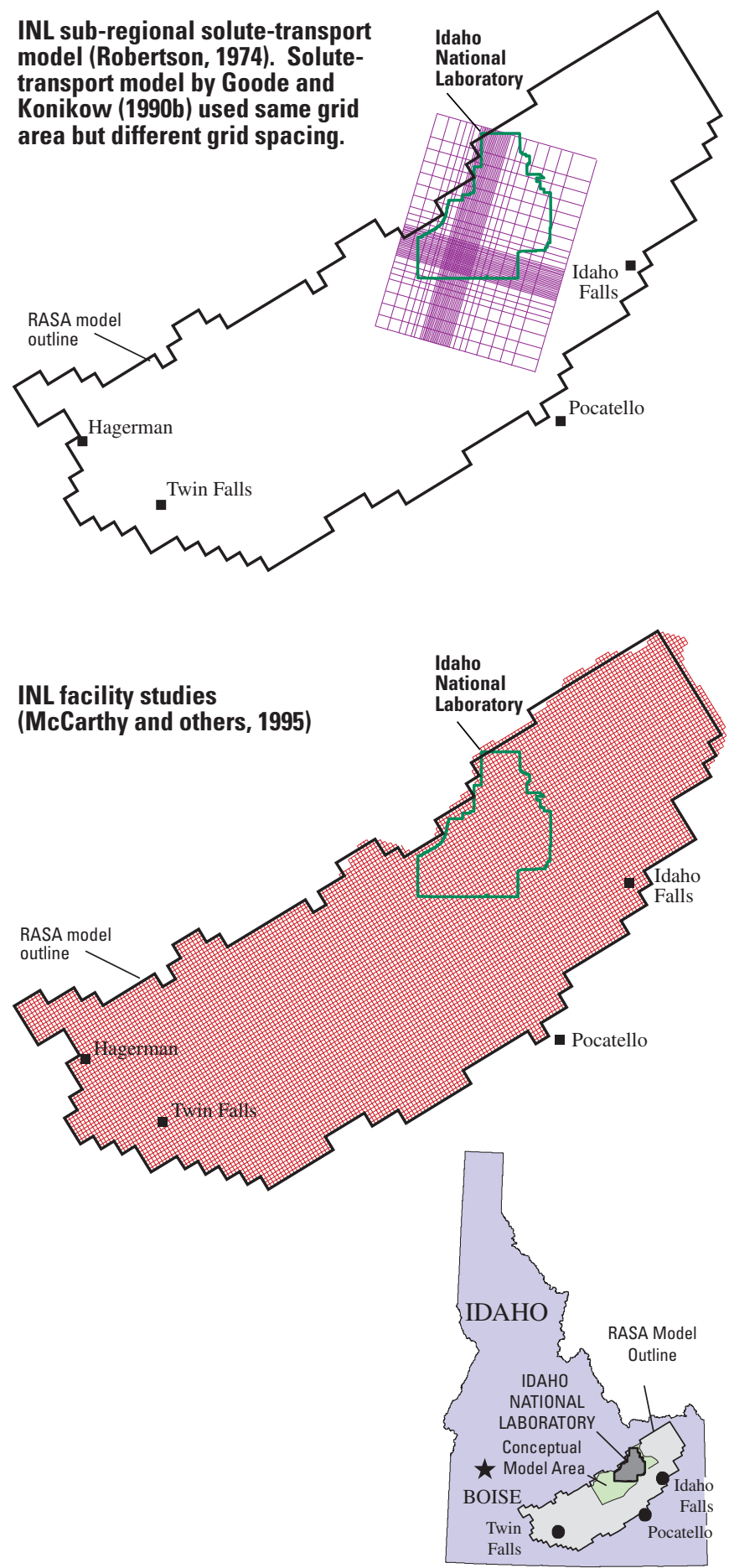

Figure 5. Areas and grid sizes of ground-water models of the eastern Snake River Plain aquifer at the Idaho National Laboratory (INL) and vicinity, Idaho, relative to those of the Snake River Plain Regional Aquifer System Analysis (RASA) model. 


\section{Conceptual Model of Ground-Water Flow}

Numerous and complex hydrogeologic and hydrologic data used to develop the conceptual model are described in six sections of this report: (1) "Hydrogeologic Framework and Hydraulic Properties," which defines three hydrogeologic units, and the structural features and hydraulic properties of these hydrogeologic units that affect ground-water flow in the model area; (2) "Model Boundaries," which defines the location of the three physical and three artificial hydrologic boundaries of the model; (3) "Inflows, Outflows, and Fluxes Across Model Boundaries," which characterizes the model boundaries and describes inflows, outflows, and fluxes across the boundaries; (4) "Ground-Water Budget," which summarizes model inflows and outflows and analyzes uncertainties of the water-budget components; (5) "GroundWater Movement," which describes the hydraulic gradient, ground-water flow directions, and average linear ground-water velocities in the model area; and (6) "Model Representation of Features Affecting Ground-Water Flow," which describes the stratigraphic, structural, and hydrologic controls on groundwater flow in the model area. The report concludes with a brief section titled "Implications for Contaminant Transport" which summarizes those features of the conceptual model that most affect interpretations of contaminant transport in the aquifer at the INL and vicinity.

\section{Hydrogeologic Framework and Hydraulic Properties}

The hydrogeologic framework is primarily based on broad differences in the lithology and large variations in the hydraulic properties of the heterogeneous, anisotropic basaltflow groups, sedimentary interbeds, and other rocks that allow these rocks to be grouped into three homogeneous and anisotropic hydrogeologic units. In the unsaturated zone and aquifer beneath the INL, basalt makes up about 85 percent of the volume of rocks and sediment makes up most of the remainder (Anderson and Liszewski, 1997, p. 11). These and other rocks form at least 178 basalt-flow groups, 6 andesiteflow groups, 103 sedimentary interbeds, and 4 rhyolite domes (Anderson and Liszewski, 1997, p. 21, table 4). The aquifer includes at least 65 basalt-flow groups, 5 andesite-flow groups, 61 sedimentary interbeds, and 3 rhyolite domes. Detailed surficial mapping and correlation of subsurface stratigraphic units among numerous outcrops and 333 wells at and near the INL (Kuntz and others, 1994; Anderson and others, 1996a) indicated that many of these stratigraphic units are continuous across large parts of the model area. Stratigraphic units were combined by Anderson and Liszewski (1997, p. 14), based on their similar age, into 14 composite stratigraphic units, each made up of from 5 to 90 (Anderson and Liszewski, 1997, p. 14 and table 4) stratigraphic units of similar age (fig. 6).

Structural features in the model area include (1) rhyolite domes (Kuntz and others, 1994), (2) sedimentary troughs (Gianniny and others, 1997), (3) areas of subsidence, uplift, and dipping beds (Anderson and others, 1997, Anderson and Liszewski, 1997), (4) volcanic rift zones, which are broad belts of focused volcanism that generally trend northwestward (fig. 7) and are perpendicular to the direction of regional ground-water flow (Kuntz and others, 1992), and (5) vent corridors, which are narrow zones in and near volcanic rift zones that contain known or inferred volcanic vents, dikes, and fissures (fig. 8) (Anderson and others, 1999, p. 13).

Hydraulic properties of the three hydrogeologic units of the conceptual model reflect the distribution of major rock types, local stratigraphic units, and structural features. Areas of high well density at the INTEC, RWMC, TRA, and TAN allowed evaluation of local variations in hydraulic properties related to the complex geology. In these areas, large variations in hydraulic properties across distances of hundreds to thousands of feet were measured. For example, horizontal hydraulic conductivity in a single vent corridor at the INTEC and TRA varies as much as three to five orders of magnitude across distances of 500 to 1,000 ft (Anderson and others, 1999, p. 27, table 2). These large variations indicate the potential complexity of the aquifer at the scale of an individual INL facility. Although this small-scale complexity cannot be duplicated at the scale of the conceptual model, it can be used as a guide for estimating hydraulic properties in the model with greater precision than was possible for the RASA study.

Hydraulic properties for the eastern SRP aquifer used in the larger scale RASA study were based on specific capacity or transmissivity and storativity estimates from medium- to high-capacity (greater than $50 \mathrm{gal} / \mathrm{min}$ ) irrigation and industrial supply wells (Mundorff, 1964; Whitehead, 1992, tables 4 and 5, Garabedian, 1992, tables 3 and 4). Transmissivity, horizontal and vertical hydraulic conductivity, storativity, and porosity at the INL and vicinity were estimated at various scales. Core-scale estimates of hydraulic conductivity and porosity are given in Knutson and others (1990, 1992). Transmissivity estimates for single-well aquifer tests (generally less than $40 \mathrm{gal} / \mathrm{min}$ ) are given in Ackerman (1991, table 2) and Bartholomay and others (1997, table 3). Additional single-well aquifer tests, slug tests, and packer tests are summarized in Welhan and Wylie (1997) and Welhan and others (2002a). Estimates of horizontal and vertical hydraulic conductivity and of storativity from multi-well aquifer tests are given in Spinazola (1994), Frederick and Johnson (1996), and Wood and Norrell (1996). 


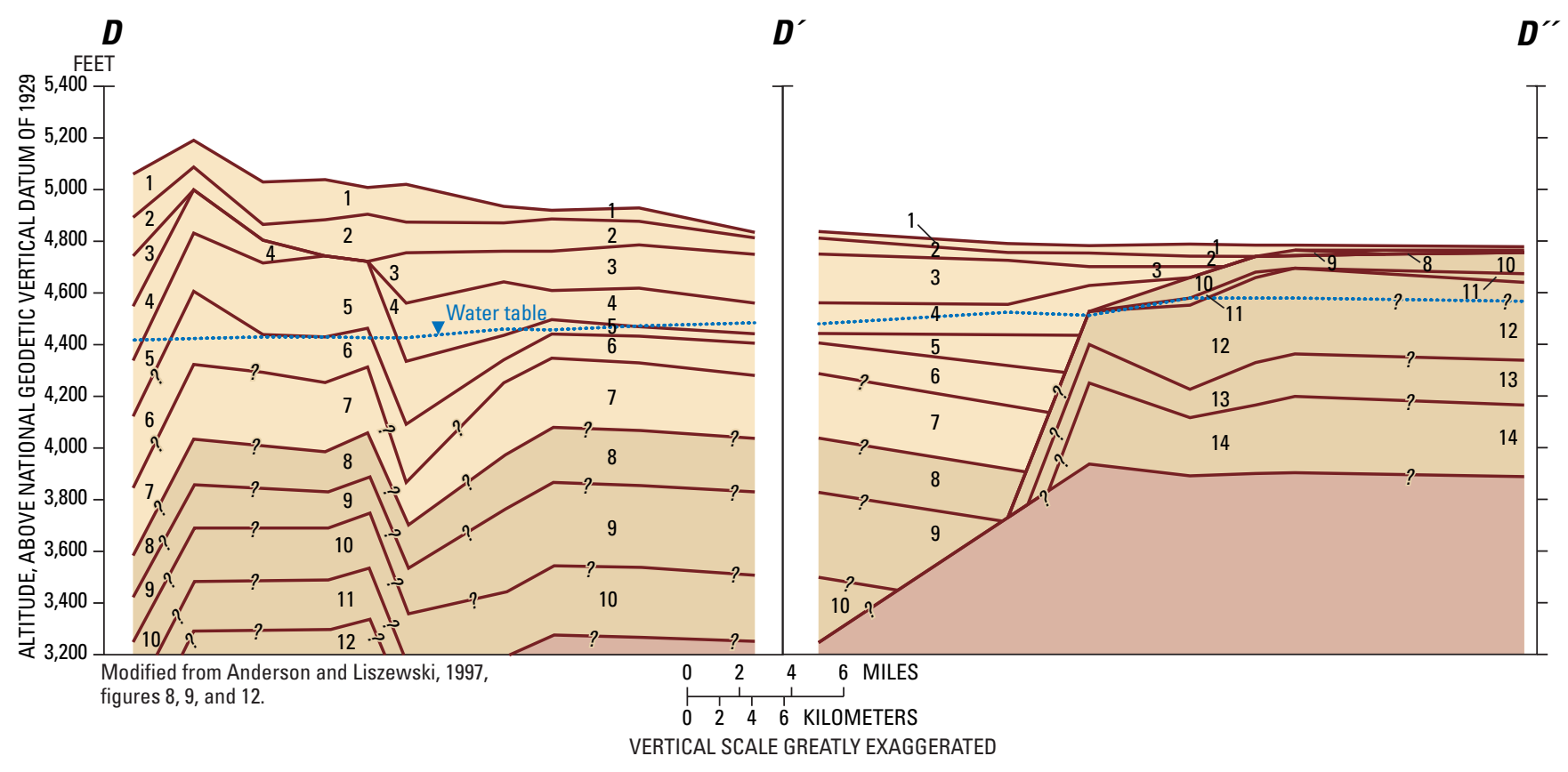

EXPLANATION
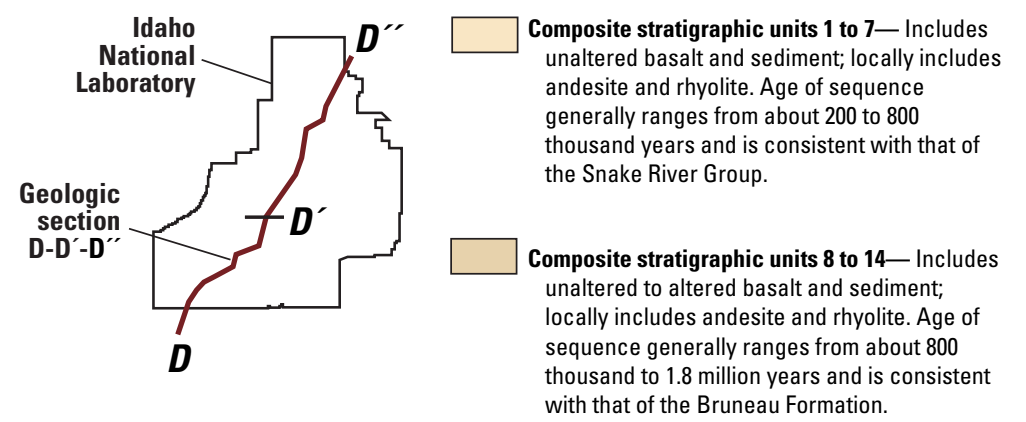
Rocks that form the base of the Eastern
Snake River Plain aquifer-Includes altered basalt and sediment; locally may include andesite and rhyolite. Age of sequence generally ranges from about 1.8 to 4 million years and is consistent with that of the Glenns Ferry Formation.

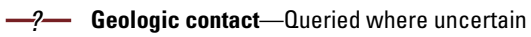

Figure 6. Composite stratigraphic units that form the eastern Snake River Plain aquifer, Idaho National Laboratory and vicinity, Idaho.

Hydraulic conductivity of the basalts of the eastern SRP aquifer at the INL and vicinity range from about 0.01 to $24,000 \mathrm{ft} / \mathrm{d}$ (Anderson and others, 1999, fig. 9, table 2), more than six orders of magnitude. Almost two-thirds of these estimates exceeded $100 \mathrm{ft} / \mathrm{d}$. Hydraulic conductivities were estimated by dividing transmissivity by the total lengths of open, perforated, or screened intervals. Transmissivities of the eastern SRP aquifer range from 1.1 to $760,000 \mathrm{ft}^{2} / \mathrm{d}$, nearly six orders of magnitude (Ackerman, 1991, table 3). More than 60 percent of these estimates are greater than $20,000 \mathrm{ft}^{2} / \mathrm{d}$ (Ackerman, 1991, fig. 10). Garabedian (1992, tables 19 and 20) used a model-calibrated range of 0.45 to $9,500 \mathrm{ft} / \mathrm{d}$ for the hydraulic conductivity of all types of basalt in the RASA study.
Estimates of the fractured basalt porosity in the eastern SRP aquifer range from 0.05 to 0.27 (Nace and others, 1959, p. 58-61, table 9; Barraclough and others, 1967, p. 61 and 63; Robertson and others, 1974, p. 176; Robertson, 1974, p. 13, 1977, p. 44-45; Garabedian, 1992, p. 44-46; Ackerman, 1995, p. 10 and 22; Bishop, 1991, p. 77; Knutson and others, 1992, p. 4-21). Estimates of porosity varied greatly because they were dependent on methods, scales, and locations used to determine them. For example, porosity estimated from laboratory measurements of cores from boreholes and outcrops at and near INL facilities were different from estimates derived from larger-scale aquifer model simulations. Because porosity in the eastern SRP basalts derives mainly from interflow zones and their associated rubble, fractures, joints, and vesicles (Hughes and others, 1999, fig. 12), the larger-scale estimates of porosity for these basalts are probably more appropriate for the conceptual model. 


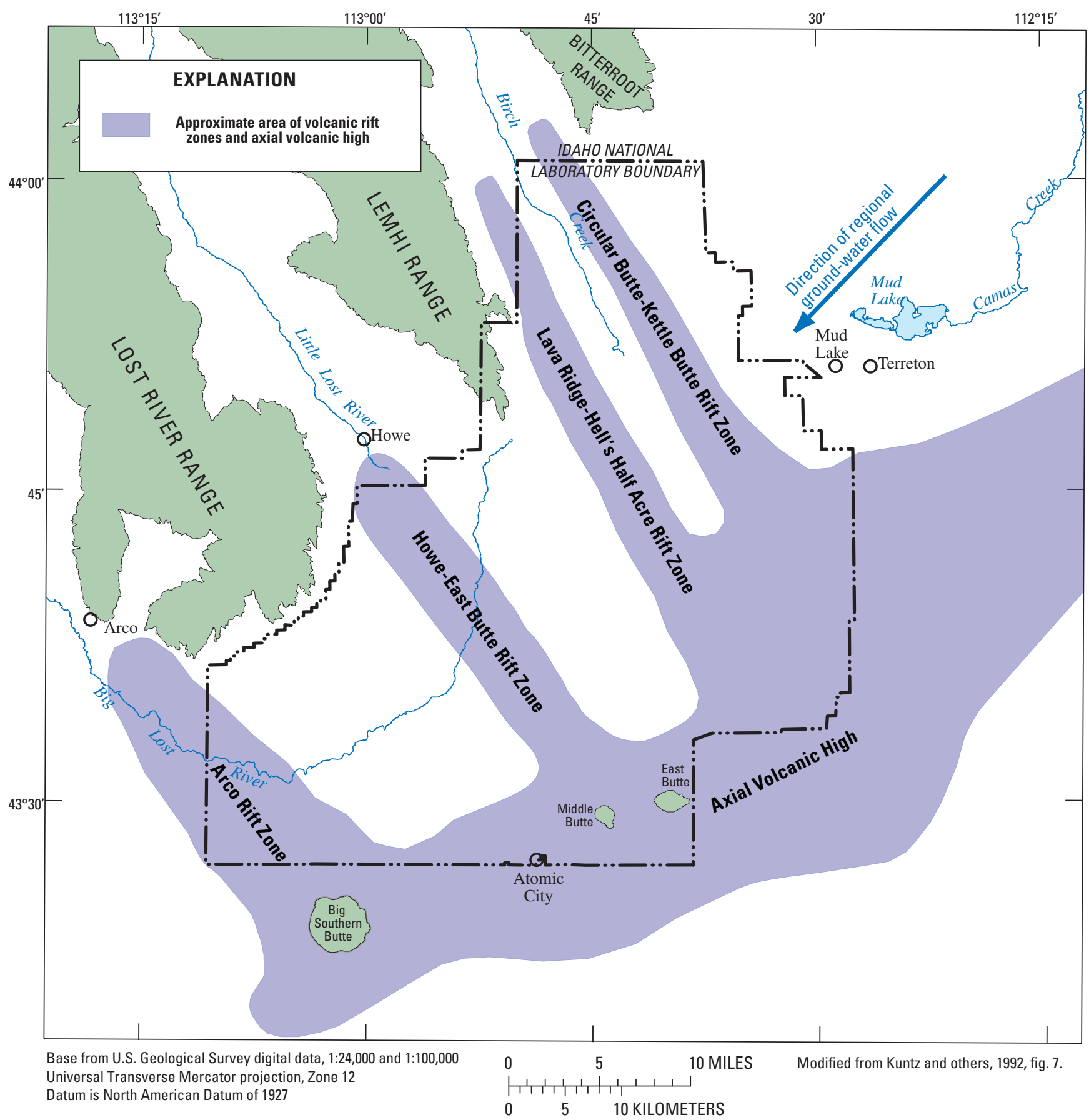

Figure 7. Approximate locations of volcanic rift zones and the axial volcanic high, Idaho National Laboratory and vicinity, Idaho. 


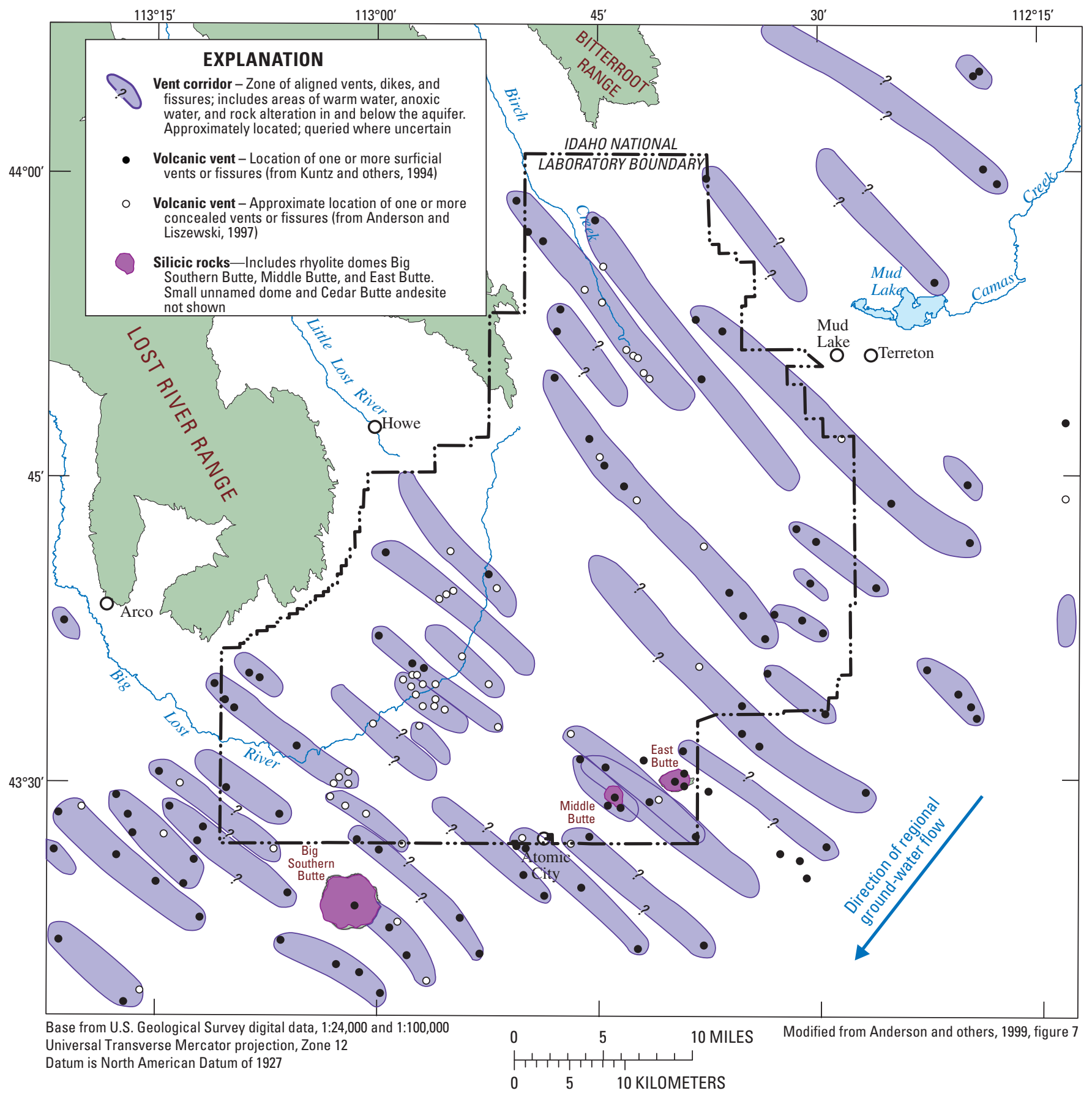

Figure 8. Locations of volcanic vents and vent corridors, Idaho National Laboratory and vicinity, Idaho. 
Interflow zones may be the most important hydraulic features of the eastern SRP aquifer because of their high permeability and their ability to localize large ground-water fluxes (Welhan and others, 2002a, p. 226). Five interflow zones identified near INTEC, in the upper $200 \mathrm{ft}$ of the aquifer, range in thickness from less than 1-ft thick to more than 18-ft thick (Jones, 1961, p. 36), and the effective thickness of interflow zones may be between 1 and $8.2 \mathrm{ft}$ (Welhan and others (2002b, p. 140). Welhan and others (2002a, p. 226-227; 2002b, p. 137-139) described two types of interflow zones. Type-I interflow zones are hosted in rubble at horizontal contacts between basalt flows and Type-II interflow zones are hosted in fracture networks along the edges of inflating lava flows (Welhan and others, 2002b, p. 136). The largest concentration of basalt fractures in eastern SRP basalts occurs at interflow zones (Welhan and others, 2002a and 2002b). Fractures in Type-I interflow zones consist of tension fractures and fractured flow tops in the upper vesicular zone. Fracturing in Type-II flow zones occur as interconnected networks of fissures along the intensely fractured margins of basalt flows that can remain partially open after burial by younger lava (Welhan and others, 2002a, p. 229).

\section{Hydrogeologic Units}

The hydrogeologic units in the model area are (1) hydrogeologic unit 1, younger rocks of thin, densely fractured basalt (440,000 to 650,000 years old) and interbedded sediment, (2) hydrogeologic unit 2, younger rocks of massive, less densely fractured basalt (650,000 to 800,000 years old) and interbedded sediment, and (3) hydrogeologic unit 3 , intermediate-age rocks of slightly altered, fractured basalt ( 800,000 to $1,800,000$ years old) and interbedded sediment (figs. 9 and $\underline{10}$ ). Other rocks of hydrogeologic importance in the model area are (1) older rocks of intensely altered basalt (older than 1,800,000 years), the top of which is interpreted to form the base of the aquifer, (2) rhyolite domes that penetrate the younger and intermediate-age rocks, and (3) sediment that is distributed throughout the younger, intermediate-age, and older rocks.

Hydrogeologic units 1, 2, and 3 correlate with the regional stratigraphy and the stratigraphy beneath the INL as defined by Anderson and Liszewski (1997) as follows: (1) hydrogeologic unit 1 is equivalent to the Snake River Group and composite stratigraphic units 4 to 6; (2) hydrogeologic unit 2 is equivalent to the Snake River Group and composite stratigraphic unit 7; and (3) hydrogeologic unit 3 is equivalent to the Bruneau Formation and composite stratigraphic units 8 to14 (fig. 11). Equivalent groups and formations were determined based on broad correlations between cores at the INL and outcrops in southern Idaho (Whitehead, 1992; Anderson and Liszewski, 1997). In the model area these composite stratigraphic units can be saturated (aquifer) or unsaturated (fig. 11).

Younger rocks form the uppermost part of the aquifer in much of the model area and, based on stratigraphic interpretations, intermediate-age rocks make up the largest volume of the aquifer in the model area. Interpreted distribution of older rocks indicates large changes in saturated thickness across the model area that may be related to differential subsidence and uplift (Anderson and Liszewski, 1997, fig. 6). In the southwestern part of the model area the hydrogeologic framework is interpreted as having a zone of differential subsidence and uplift that affects the dip of hydrogeologic units 1 and 2 (fig. 10). This interpretation, based on the trend of composite stratigraphic units 4 through 7 (Anderson and Liszewski, 1997, figs. 21, 23, 25, and 27), is uncertain due to the few core and stratigraphic data available in the southwestern part of the model area.

Hydraulic conductivities for hydrogeologic units 1, 2, and 3 and older rocks were estimated from aquifer tests in wells using straddle packers or having perforated or open intervals only in the respective hydrogeologic unit or older rocks, and hydraulic conductivities of sediment were estimated from laboratory determinations of the saturated hydraulic conductivity of core samples (table 2). Estimated hydraulic conductivity from core-scale tests were not used to estimate the hydraulic conductivities of the hydrogeologic units or older rocks because they reflect the character of the rock matrix and are not representative of the magnitude and spatial variability of hydraulic conductivity estimated from field-scale tests arising from larger-scale heterogeneities (Welhan and others, 2002a, p. 229). These core-scale tests have minimum and median values 3 to 4 orders of magnitude less than fieldscale test results (Welhan and others, 2002a, fig. 3). 


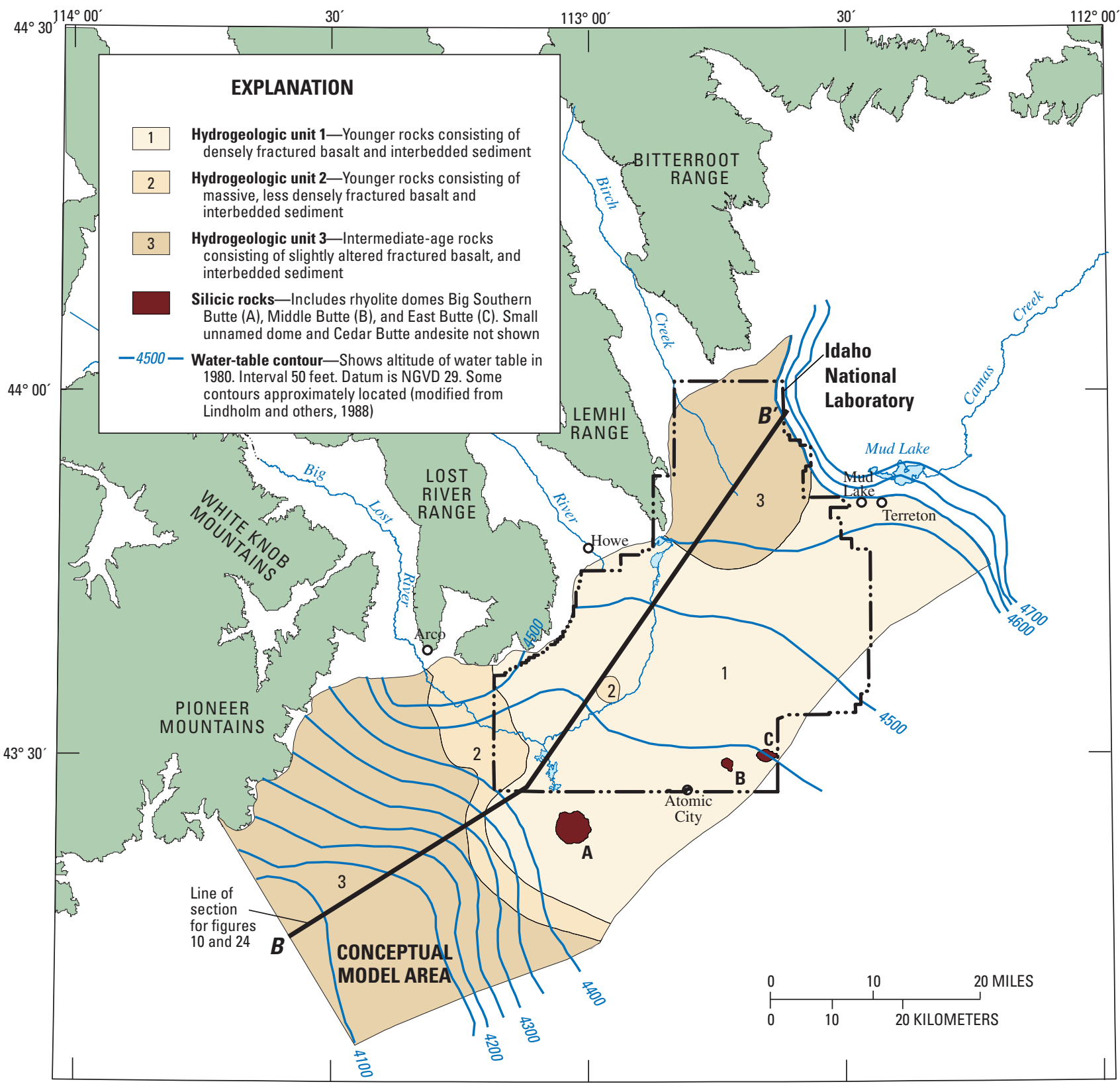

Base from U.S. Geological Survey digital data, 1:24,000 and 1:100,000

Universal Transverse Mercator projection, Zone 12

Datum is North American Datum of 1927

Figure 9. Distribution of hydrogeologic units present at the water table and water-table contours for 1980 in the model area, Idaho National Laboratory and vicinity, Idaho. 
FEET

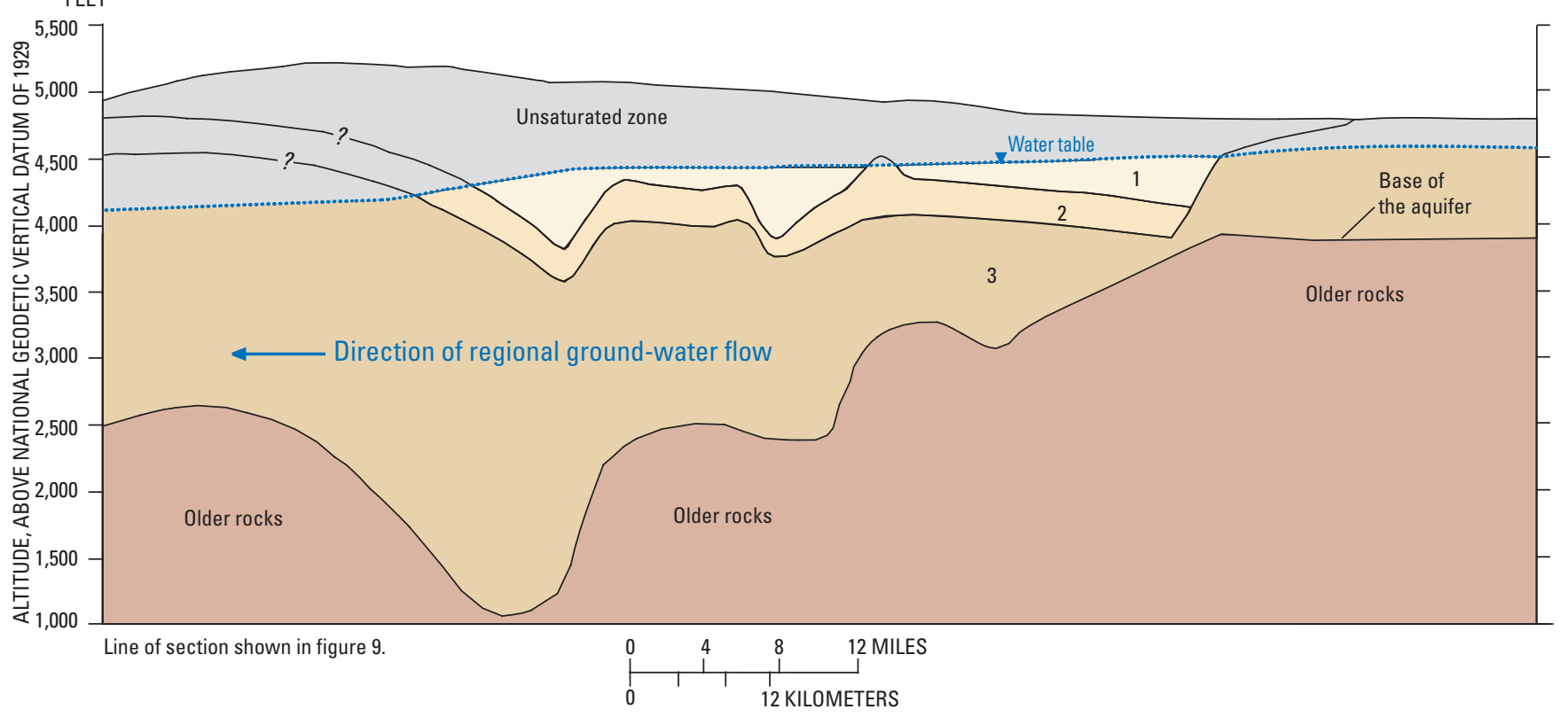

VERTICAL SCALE GREATLY EXAGGERATED

\section{EXPLANATION}

1 Hydrogeologic unit 1-Younger rocks consisting of densely fractured 2 Hydrogeologic unit 2-Younger rocks basalt and interbedded sediment fractured basalt and interbedded

3 Hydrogeologic unit 3-Intermediate-
age rocks consisting of slightly

altered fractured basalt and

interbedded sediment

Figure 10. Distribution of hydrogeologic units along the direction of regional ground-water flow in the model area, Idaho National Laboratory and vicinity, Idaho. 


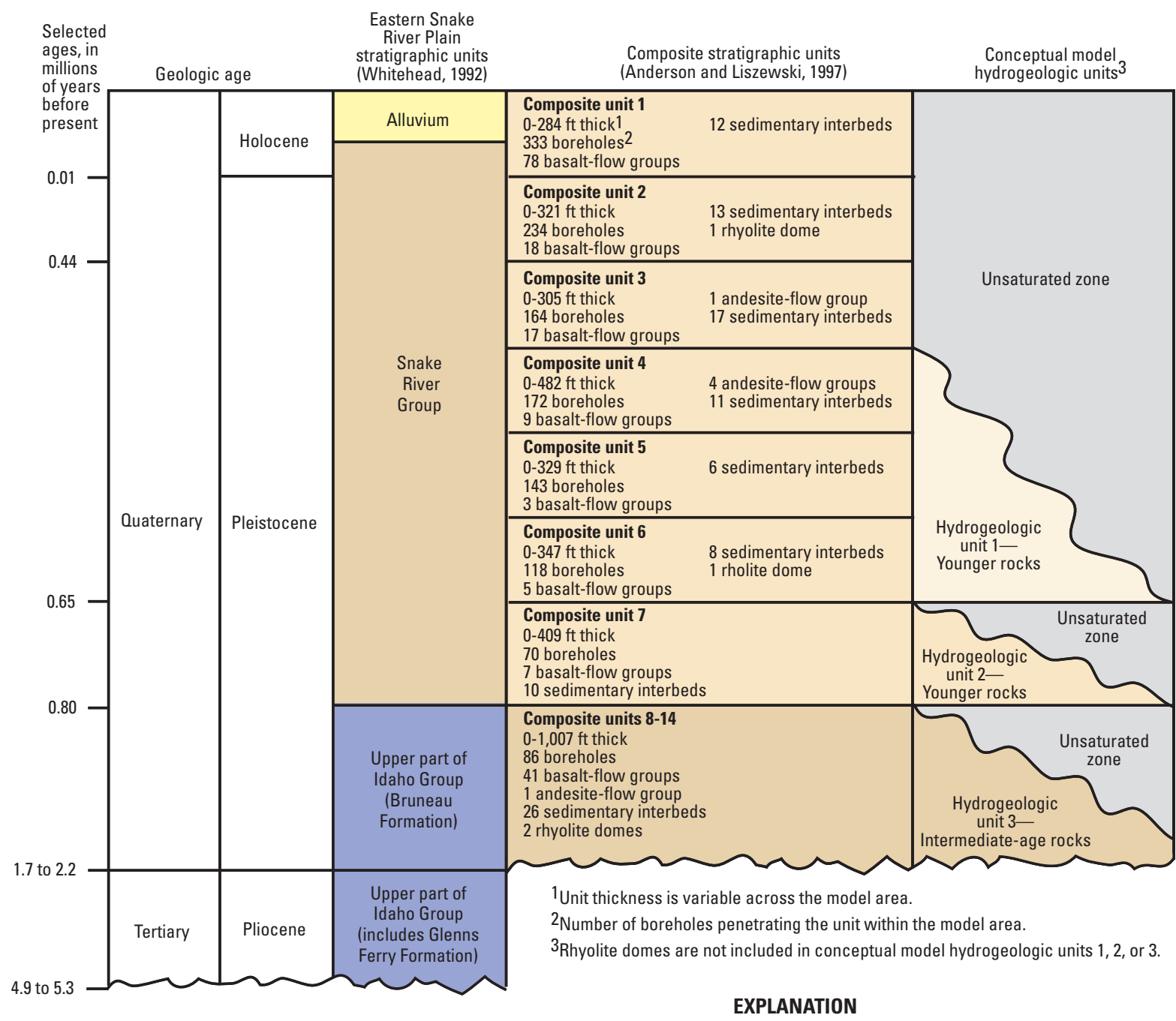

Transition from unsaturated to saturated zone occurs within or between several different composite stratigraphic units and conceptual model hydrogeologic units.

Figure 11. Correlation among stratigraphic units of the eastern Snake River Plain, composite stratigraphic units beneath the Idaho National Laboratory, and hydrogeologic units of the conceptual model, Idaho National Laboratory and vicinity, Idaho. 
Table 2. Ranges of hydraulic conductivities and porosities for hydrogeologic units and other rocks of hydrogeologic importance, Idaho National Laboratory and vicinity, Idaho.

[Conductivities for thin, densely fractured basalt; massive, less densely fractured basalt; intermediate-age rocks; and older rocks were estimated from aquifer tests in wells having perforated or open intervals only within the respective hydrogeologic unit or rock. Values were calculated from stratigraphic and hydraulic data presented by Mann (1986), Wood and Norrell (1996, table 6-2), Anderson and Liszewski (1997), and Anderson and others (1999, table 2). Saturated hydraulic conductivities for sediment were measured in the laboratory on intact core samples from the unsaturated zone using either the constant- or falling-head method and were reported by McElroy and Hubbell, 1990, p. 23; Perkins and Nimmo, 2000, table 1; Perkins, 2003, table 1; Winfield, 2003, table 1; Winfield, 2005, table 2. Values for porosity were measured in the laboratory on core samples and were reported by Nace and others, 1959, p. 58-61, table 9; Barraclough and others, 1967b, p. 61 and 63; Knutson and others, 1992, p. 4-21; Robertson, 1977, p. 21; McElroy and Hubbell, 1990, p. 23; Perkins and Nimmo, 2000, table 1; Perkins, 2003, table 1; Winfield, 2003, table 1; Winfield, 2005, table 2. Abbreviations: $\mathrm{ft} / \mathrm{d}$, foot per day; 100s, hundreds; <, less than]

\begin{tabular}{|c|c|c|c|c|c|}
\hline \multirow{3}{*}{ Hydrogeologic unit or rock } & \multicolumn{5}{|c|}{ Property and sample data } \\
\hline & \multicolumn{2}{|c|}{$\begin{array}{l}\text { Hydraulic conductivity } \\
\qquad(\mathrm{ft} / \mathrm{d})\end{array}$} & \multirow{2}{*}{$\begin{array}{l}\text { Number of } \\
\text { wells }(w) \text { or } \\
\text { core samples } \\
\text { (c) }\end{array}$} & \multirow{2}{*}{$\begin{array}{l}\text { Range or } \\
\text { median } \\
\text { porosity }\end{array}$} & \multirow{2}{*}{$\begin{array}{c}\text { Number of } \\
\text { core samples }\end{array}$} \\
\hline & Smallest & Largest & & & \\
\hline $\begin{array}{l}\text { Hydrogeologic unit } 1 \text {-Younger rocks } \\
\text { consisting of thin, densely fractured } \\
\text { basalt }\end{array}$ & 0.01 & 24,000 & $67(w)$ & 0.05 to 0.27 & $100 \mathrm{~s}$ \\
\hline $\begin{array}{l}\text { Hydrogeologic unit } 2 \text { - Younger rocks } \\
\text { consisting of massive, less densely } \\
\text { fractured basalt }\end{array}$ & 6.5 & 1,400 & $4(w)$ & ${ }^{1} 0.11$ & $100 \mathrm{~s}$ \\
\hline $\begin{array}{l}\text { Hydrogeologic unit 3-Intermediate-age } \\
\text { rocks consisting of slightly altered } \\
\text { fractured basalt and interbedded } \\
\text { sediment }\end{array}$ & .32 & 24,000 & $14(w)$ & 0.05 to 0.08 & 20 \\
\hline $\begin{array}{l}\text { Older rocks consisting of intensely altered } \\
\text { fractured basalt and rhyolitic ash-flow } \\
\text { tuffs }\end{array}$ & .002 & .03 & $1(\mathrm{w})$ & $<0.09$ to 0.19 & 19 \\
\hline Sediment & .000032 & 240 & $109(\mathrm{c})$ & 0.25 to 0.73 & $100 \mathrm{~s}$ \\
\hline
\end{tabular}

${ }^{1}$ Median value.

\section{Younger Rocks}

Younger rocks (hydrogeologic units 1 and 2) make up the unsaturated zone throughout most of the model area and the uppermost part of the aquifer in the central part of the model area (figs. 9 and 10). Sediment content is largest in the younger rocks in a sedimentary trough, known as the Big Lost Trough, in the northern part of the model area. Petrographic analyses of cores of the younger rocks from wells at and immediately north of the INTEC (Lanphere and others, 1993, p. 19-33) indicated that alteration was rare and weak and that secondary mineralization consisted of thin coats of carbonate minerals. The younger rocks also include four rhyolite domes [fig. 9, rhyolite domes A, B, C, and an unnamed dome (not shown in fig. 9) between B and C].

\section{Hydrogeologic Unit 1 (Thin, Densely Fractured Basalt)}

Hydrogeologic unit 1 comprises 17 basalt-flow groups, 4 andesite-flow groups, and 25 sedimentary interbeds (fig. 11) (Anderson and Liszewski, 1997, p. 16-17, figs. 9-15). These thin, densely fractured basalt flows are mostly $14-$ to $24-\mathrm{ft}$ thick (table 3) tube-fed pahoehoe flows having thin, massive interiors (Anderson and others, 1999). Mean thickness of the basalt flows in hydrogeologic unit 1 is $20 \mathrm{ft}$.

Hydraulic conductivity and porosity of hydrogeologic unit 1 primarily is controlled by void spaces of interconnected interflow zones. Other factors that probably modify the hydraulic conductivity and porosity of the fractured basalt include near-vent deposits, dikes, fissures, and tension cracks within volcanic rift zones and vent corridors (Anderson and 
Table 3. Summary statistics of basalt flow thickness within individual hydrogeologic units, Idaho National Laboratory and vicinity, Idaho.

[Data compiled from Anderson and others (1996, table 8)]

\begin{tabular}{|c|c|c|c|c|c|c|c|}
\hline \multirow[b]{2}{*}{ Hydrogeologic unit } & \multicolumn{7}{|c|}{ Basalt flow thickness (feet) } \\
\hline & Minimum & First quartile & Median & Mean & Third quartile & Maximum & $\begin{array}{c}\text { Number of } \\
\text { flows }\end{array}$ \\
\hline Unit 1 & 2 & 14 & 18 & 20 & 24 & 54 & 1,095 \\
\hline Unit 2 & 4 & 21 & 28 & 29 & 37 & 78 & 212 \\
\hline Unit 3 & 2 & 15 & 22 & 23 & 28 & 107 & 441 \\
\hline
\end{tabular}

others, 1999, p. 27). Secondary mineralization is uncommon in these rocks, except where carbonates fill vesicles near the land surface (Nace and others, 1975, p. 13).

Results of single-well aquifer tests in 67 wells with perforated or open intervals only in hydrogeologic unit 1 indicated that the hydraulic conductivity of these rocks ranges from about 0.01 to $24,000 \mathrm{ft} / \mathrm{d}$ (table 2), more than six orders of magnitude. Almost two-thirds of these estimates were larger than $100 \mathrm{ft} / \mathrm{d}$ and about one-third were larger than 1,000 ft/d. Estimates larger than $100 \mathrm{ft} / \mathrm{d}$ primarily are associated with interflow zones of thin pahoehoe flows (Anderson and others, 1999, p. 27). Many estimates of hydraulic conductivity smaller than $100 \mathrm{ft} / \mathrm{d}$ may be associated with dikes (Anderson and others, 1999, p. 27).

Three previous studies described specific yield, porosity, and effective porosity applicable to hydrogeologic unit 1 . In the RASA study, Garabedian (1992, p. 44-46) used an average specific yield of 0.05 for all types of basalt and silicic volcanic rocks and 0.20 for all types of sediment for the uppermost $200 \mathrm{ft}$ of the eastern SRP aquifer. Ackerman (1995, p. 10) used a range of effective porosity from 0.10 to 0.25 for simulation of advective transport in the uppermost $200 \mathrm{ft}$ of the regional aquifer system. The calibration value for this simulation, 0.21 , was based on the travel time of iodine-129 ( $\left.{ }^{129} \mathrm{I}\right)$ from disposal well CPP 3 at the INTEC to well USGS 11 near Big Southern Butte (fig. 1) (Ackerman, 1995, p. 22). Knutson and others (1992, p. 4-21 and fig. 4-10) determined the porosity of 1,504 core samples from the unsaturated zone of hydrogeologic unit 1 near the RWMC. The porosities ranged from 0.01 to 0.43 with 90 percent of values between 0.05 and 0.27 .

\section{Hydrogeologic Unit 2 (Massive, Less Densely Fractured Basalt)}

Hydrogeologic unit 2 consists of 7 basalt-flow groups, 10 sedimentary interbeds, and includes basalt-flow group I, a major basalt-flow group within composite unit 7 (fig. 11) (Anderson and Liszewski, 1997, p. 16, figs. 9-15). These massive, less densely fractured basalt flows are mostly 21- to 37-ft thick (table 3) tube-fed pahoehoe flows having thick, massive interiors (Anderson and others, 1999). Mean thickness of the basalt flows in hydrogeologic unit 2 is $29 \mathrm{ft}$ (table 3), or nearly one-and-one-half times the average thickness of the basalt flows composing hydrogeologic unit 1 . As a result of the larger average thickness of basalt flows, the basalt of hydrogeologic unit 2 is probably more massive, less densely fractured, and has fewer interflow zones than hydrogeologic unit 1 .

The massive basalt of hydrogeologic unit 2 includes basalt-flow group I, one of the thickest and most extensive flow groups near the INL (Anderson, 1991, p. 22; Wetmore and others, 1997, p. 50, table 1). The interpreted thicknesses of the other basalt-flow groups in hydrogeologic unit 2 were based entirely on natural gamma logs and are less certain than the interpretations for basalt-flow group I. Basalt-flow group I and the overlying HI interbed (a layer of clay and silt) underlie all but the northern and extreme southeastern parts of the INL (Anderson, 1991, p. 21-22; Anderson and others, 1997, p. 19). The thickness of composite stratigraphic unit 7 ranges from 0 to $409 \mathrm{ft}$, averages $266 \mathrm{ft}$ in the 15 wells that fully penetrate to its base, and is greatest in wells at the TRA near the exposed vents of basalt-flow group I. Correlations of composite stratigraphic unit 7 were primarily based on natural-gamma logs from uncored boreholes because only five coreholes within a 3-mi radius of the INTEC are known to penetrate this stratigraphic unit.

Hydraulic conductivity and porosity of hydrogeologic unit 2 generally are less than hydrogeologic unit 1 because of the thick, massive interiors and fewer interconnected interflow zones in the massive, less densely fractured basalt. Other factors that probably modify the hydraulic conductivity and porosity of the fractured basalt include sediment-filled interflow zones and near-vent deposits, dikes, fissures, and tension cracks in volcanic rift zones and vent corridors (Anderson and others, 1999, p. 27). Secondary mineralization is uncommon in these rocks, except where carbonates fill vesicles near the land surface (Nace and others, 1975, p. 13).

Estimated hydraulic conductivity of hydrogeologic unit 2 ranged from 6.5 to $1,400 \mathrm{ft} / \mathrm{d}$ for single-well aquifer tests in four wells with perforated intervals only in hydrogeologic unit 2 (table 2). This range of conductivities is similar to conductivity ranges estimated for massive basalt of the 
Columbia Plateau (Anderson and others, 1999, p. 22 and 27), results of flowmeter tests in two wells penetrating part of unit 2 (Morin and others, 1993, p. 23 and 26), and numerical model simulations of aquifer tests that include unit 2 (Frederick and Johnson, 1996, p. 63, layer 3).

Porosity of the massive basalt of hydrogeologic unit 2 probably is within the lower end of the range estimated for that of the densely fractured basalt of hydrogeologic unit 1, 0.05 to 0.27 . Knutson and others (1992, p. 4-21) reported a median porosity of 0.11 for hundreds of nonvesicular basalt cores, a measure that may approximate the porosity of massive basalt because it does not include the effects of porous interflow zones.

\section{Intermediate-Age Rocks (Hydrogeologic Unit 3)}

Intermediate-age rocks of hydrogeologic unit 3 underlie younger rocks in the model area, except for the area northwest of the Big Lost River (Anderson and Liszewski, 1997, fig. 30) (fig. 1) where the intermediate-age rocks are not present. The intermediate-age rocks constitute the full thickness of the aquifer in the northern part of the INL and in the southwestern part of the model area (figs. 9 and 10). Hydrogeologic unit 3 consists of 41 basalt-flow groups, 1 andesite-flow group, and 26 sedimentary interbeds (fig. 11) (Anderson and Liszewski, 1997, p. 17-18, figs. 9-15). Sediment content is greatest in a sedimentary trough, known as the Big Lost Trough, in the northern part of the model area. Average thickness of fractured basalt flows in hydrogeologic unit 3 is $23 \mathrm{ft}$ and 50 percent of the flows are between 15- and 28-ft thick (table 3 ).

Basalt flows of hydrogeologic unit 3 are slightlyto-moderately altered (Whitehead, 1992, p. 10, table 3; Lanphere and others, 1994, p. 22-39; Fromm and others, 1994; Anderson and Liszewski, 1997, p. 28). Detailed analysis of petrography of cores from wells near TAN indicates that intermediate-age rocks near TAN contain secondary porefilling minerals such as calcite (Lanphere and others, 1994, p. 22-39). Calcite also is commonly present in the vesicles and fractures of these rocks. This alteration and the larger average thickness of the basalt flows, compared with the thickness of basalt flows in hydrogeologic unit 1 (Whitehead, 1992, p. 11-13), result in fewer interflow zones and a smaller hydraulic conductivity and porosity for hydrogeologic unit 3 than for hydrogeologic unit 1 .

Results of single-well aquifer tests in 14 wells with perforated or open intervals only in hydrogeologic unit 3 indicated that the hydraulic conductivity of these rocks ranges from about 0.32 to $24,000 \mathrm{ft} / \mathrm{d}$ (table 2). However, a comparison of 24 hydraulic conductivity estimates near the INTEC with 68 estimates near TAN indicate that the average hydraulic conductivity of intermediate-age rocks near TAN is about one order of magnitude smaller than younger rocks (hydrogeologic units 1 and 2 undifferentiated) near the INTEC (John Welhan, Idaho State Geological Survey, written commun., 1999). Welhan calculated a median and geometric mean hydraulic conductivity of 500 and $130 \mathrm{ft} / \mathrm{d}$ for younger rocks near the INTEC and 30 and $20 \mathrm{ft} / \mathrm{d}$ for the intermediateage rocks near TAN. In the analysis of the regional aquifer system, Garabedian (1992, p. 42) accounted for this difference by decreasing the hydraulic conductivity of lower model layers by as much as two-thirds.

Porosity of hydrogeologic unit 3 probably is within the lower end of the range of that estimated for the densely fractured basalt of hydrogeologic unit $1,0.05$ to 0.27 . Median values of porosity reported for 10 nonvesicular and 10 vesicular basalt cores from the intermediate-age rocks at TAN were about 0.05 and 0.08 , respectively (Allan Wylie, Idaho Water Resources Research Institute, written commun., 2000). Median values of porosity reported for hundreds of nonvesicular and vesicular basalt cores from the younger rocks (hydrogeologic units 1 and 2) at and near the RWMC were 0.11 and 0.22 , respectively (Knutson and others, 1992, p. 4-21). Although these values do not include porosity of interflow zones, they indicate that porosity of intermediate-age rocks may be smaller than that of younger rocks.

\section{Older Rocks}

Older rocks ( $\mathrm{Tb}, \mathrm{Tsv}$, and QTb in fig. 4) underlie intermediate-age rocks throughout most of the model area and contain intensely altered basalt (which generally is equivalent to the Glenns Ferry Formation), Miocene rhyolitic ash-flow tuffs (figs. 4 and 11), and interbedded sediment. Only a few estimates of hydraulic conductivity and porosity were available for the older rocks. Based on analyses from four aquifer tests, Mann (1986, p. 21) reported a range of 0.002 to $0.03 \mathrm{ft} / \mathrm{d}$ for hydraulic conductivity of altered basalt, interbedded sediment, and rhyolitic ash-flow tuffs that make up the older rocks. Nace and others (1959, table 9) reported two measurements of porosity for older basalt, both about 0.19 , at a spring in the discharge area of the eastern SRP aquifer. This value is greater than the median porosity, about 0.09 , of 17 cores of altered basalt obtained from the older rocks at well WO2 (fig. 1), about 3 mi east of the INTEC (Carroll Knutson, EG\&G Idaho, Inc., written commun, 1992).

\section{Rhyolite Domes}

Rhyolite domes in the model area are clustered in two areas (fig. 9; rhyolite domes A, B, C, and an unnamed dome between $\mathrm{B}$ and $\mathrm{C}$ that is not shown in fig. 9). Rhyolite domes are vertical plug-like masses (Qsv in fig. 4) interpreted to penetrate a large thickness of the younger rocks and intermediate-age rocks (Kuntz and Dalrymple, 1979, p. 30-34; Spear and King, 1982, p. 396-400; Kuntz and others, 1994; Hughes and others, 1999, fig. 16; McCurry and others, 1999, p. 170-174). Big Southern Butte is the largest of four rhyolite domes. Other domes, Middle Butte, East Butte, and an older unnamed dome of small surficial extent between Middle Butte and East Butte, are near the southeast boundary of the model area. 
Hydraulic properties of rhyolite domes have not been measured; however, based on rock characteristics, water-table contours (Bartholomay and others, 1997, fig. 9), and well Corehole 1 ( $\mathrm{CH} 1$ in fig. 1) that penetrates the saturated part of the unnamed dome (Kuntz and Dalrymple, 1979, fig. 5; Morse and McCurry, 1997, fig. 2; McCurry and others, 1999, fig. 3), rhyolite domes probably have low permeability and may have hydraulic properties similar to those of the massive basalt of hydrogeologic unit 2. A temperature log of Corehole 1 (Morse and McCurry, 2002, fig. 2) indicates that most of the unnamed dome is in hydraulic contact with the cold water of the aquifer. However, inferred water-table contour deflections around this dome and Middle and East Buttes (fig. 12) probably indicates that the hydraulic conductivity of these rocks is smaller than that of adjacent fractured basalt. The lack of a similar deflection of contours near Big Southern Butte probably indicates that this dome is fractured at depth or may lie above the water table. If the hydraulic conductivity and porosity of rhyolite domes are similar to that of the massive basalt of hydrogeologic unit 2 , then the conductivity probably ranges from about 6.5 to $1,400 \mathrm{ft} / \mathrm{d}$ and the porosity is probably within the lower end of the 0.05 to 0.27 range of porosity estimated for hydrogeologic unit 1 . In the RASA study, Garabedian (1992, p. 44-46, tables 19 and 20) used a model-calibrated value of $0.65 \mathrm{ft} / \mathrm{d}$ for hydraulic conductivity and a value of 0.05 for specific yield of silicic volcanic rocks.

\section{Sediment}

Sediment in the model area is interbedded with basalt and deposited in four overlapping depositional environments in younger rocks, intermediate-age rocks, and older rocks (Whitehead, 1992; Kuntz and others, 1994; Anderson and others, 1996a, b). Sediment deposited in the first depositional environment consists of thin layers of windblown sediment that are present throughout most of the model area (Nace and others, 1975, p. 35; Anderson and others, 1996b, p. 3). Sediments from the second depositional environment range from fluvial, sandy gravel in stream channels to finer-grained clayey silt in terminal playas at the distal ends of river systems (Nace and others, 1975, p. 19-27; Gianniny and others, 1997, p. 31). Mainly thick layers of clay and silty clay lacustrine deposits in an area of closed topographic depressions at and near Mud Lake (Stearns and others, 1939, p.17, 39; Spinazola, 1994, p.10) constitute sediment from the third depositional environment. Alluvial deposits along and near the mouths of tributary valleys and adjacent mountain fronts mainly constitute sediment from the fourth depositional environment.

Sedimentary deposits along and near the channel, floodplain, sinks, and playas of the Big Lost River are referred to as the Big Lost Trough (Gianniny and others, 1997, p. 31). The definition of the Big Lost Trough is expanded in this report beyond that of Gianniny and others (1997, p. 31) to include the coalescing sedimentary deposits along and near the channel, floodplain, sinks, and playas of the Big Lost River, Little Lost River, Birch Creek, Camas Creek, and Mud Lake (fig. 12). Two interpretations of the Big Lost Trough are shown in figure 12 to account for differences in methods, data, and interpolation techniques used to evaluate the distribution of sediment. Figure $12 \mathrm{~A}$ shows an area, interpreted from drill logs (Whitehead, 1992, pl. 5), where sediment was estimated to compose from 100 to $999 \mathrm{ft}$ of the stratigraphic section (including the older rocks). Figure $12 \mathrm{~B}$ shows an area where sediment was estimated to compose more than 11 percent of the stratigraphic section (excluding the older rocks) based on interpretations from the geologic map of the INL (Kuntz and others, 1994) and natural-gamma logs from wells drilled to depths of more than $300 \mathrm{ft}$ below land surface (Anderson and others, 1996a, b). Sedimentary deposits compose from less than 1 percent to 50 percent of the rocks penetrated by wells in the model area. Although sediment is present throughout the stratigraphic section of the model area, it is not represented with separate hydrogeologic units, but is included in younger rocks (hydrogeologic units 1 and 2), intermediate-age rocks (hydrogeologic unit 3), and older rocks.

Estimates of hydraulic conductivity and porosity measured by or estimated for previous studies reflect the wide range of characteristics of the sedimentary interbeds beneath the INL. For example, laboratory determinations of saturated hydraulic conductivity for 109 core samples from selected sedimentary interbeds at and near the RWMC range from about 0.000032 to $240 \mathrm{ft} / \mathrm{d}$ (McElroy and Hubbell, 1990; Winfield, 2005). Reported textures of these samples range from clay to sand. By comparison, for the RASA study, Garabedian (1992, tables 19 and 20) used model-calibrated ranges of hydraulic conductivity from 0.0033 to $0.65 \mathrm{ft} / \mathrm{d}$ for silt and clay, 0.65 to $5,200 \mathrm{ft} / \mathrm{d}$ for sand, and 33 to $17,000 \mathrm{ft} / \mathrm{d}$ for sand and gravel. Robertson (1977, p. 21) reported a range in porosity of from 0.25 to 0.45 for selected surficial sediments. Laboratory determinations of porosity for 109 core samples from selected sedimentary interbeds at and near the RWMC and INTEC range from about 0.33 to 0.73 (McElroy and Hubbell, 1990, table 8; Perkins and Nimmo, 2000, table 1; Perkins, 2003, table 1; Winfield, 2003, table 1; Winfield, 2005, table 2). Estimates of effective porosity used for modeling contaminant movement through the unsaturated zone at the INL were 0.30 and 0.35 (Robertson, 1977, p. 31, 45). In the RASA study, Garabedian (1992, p. 44-46) specified a value of 0.20 for the specific yield of sediments.

Hydraulic properties of interbedded sediment probably significantly influence the hydraulic properties of basalt in the eastern SRP aquifer. However, because hydraulic conductivity and porosity for sediment were available for only a few sedimentary interbeds in the model area and were not available for complete interflow zones, the influence of sediment on hydraulic properties of hydrogeologic units was not directly included in the conceptual model. For instance, in areas where large amounts of sediment were deposited, such 


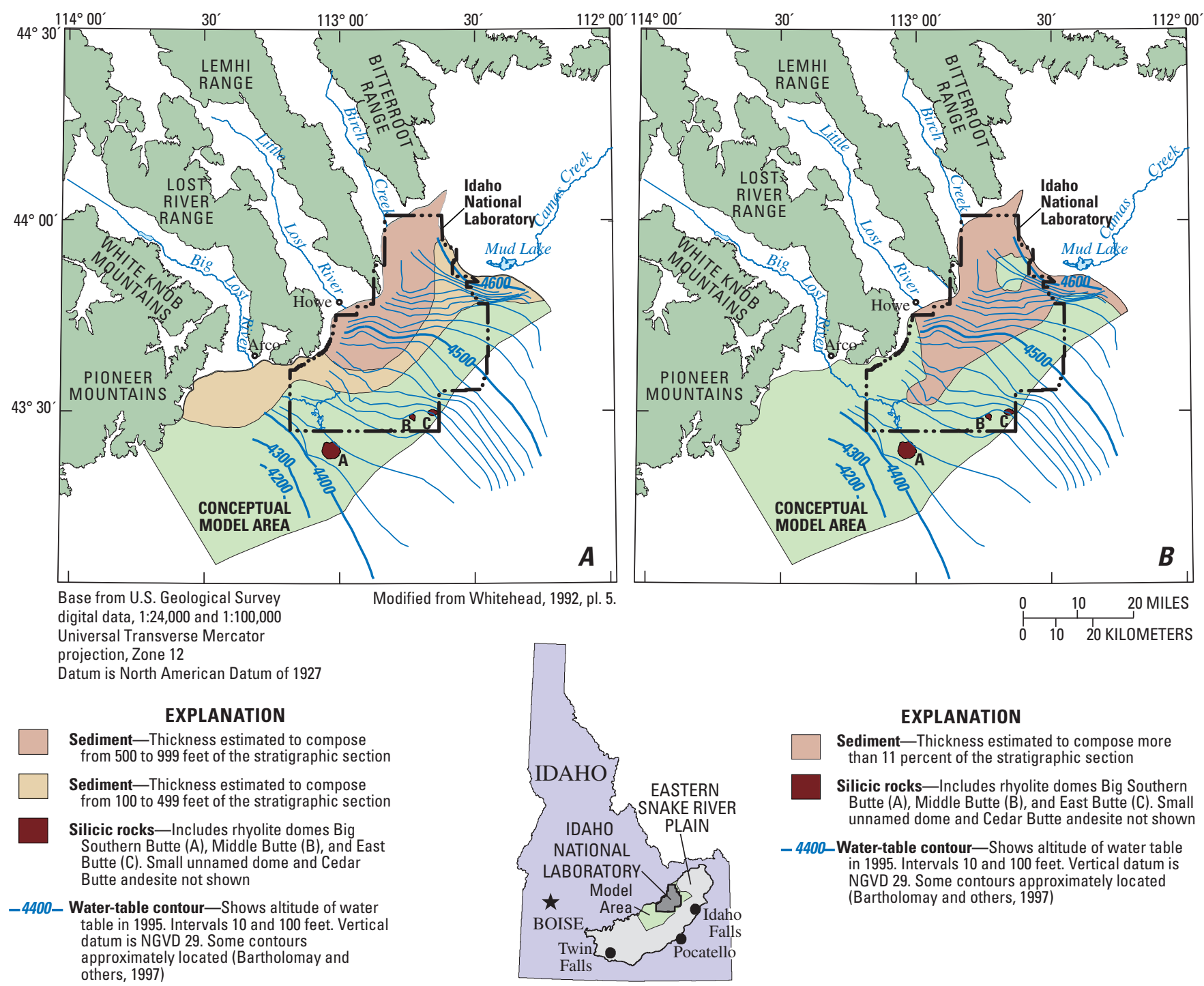

Figure 12. Water-table contours, 1995, and areas of abundant sediment within the model area, Idaho National Laboratory and vicinity, Idaho.

Areas interpreted from $(A)$ drill logs and $(B)$ geologic map and natural-gamma logs.

as in the Big Lost Trough, hydraulic conductivity of basalt interflow zones probably is greatly reduced because sediment fills cracks, joints, fissures, and fractures, reducing the original porosity of the basalt and impeding ground-water flow. The effects of sedimentary deposits on hydraulic conductivities of hydrogeologic units could be estimated with a numerical model.

\section{Model Boundaries}

The model area, in the west-central part of the eastern SRP aquifer, is bounded by three physical and three artificial hydrologic boundaries. Physical boundaries are the water-table boundary, base of the aquifer, and northwest mountain-front boundary. Artificial boundaries are the northeast boundary, southeast-flowline boundary, and southwest boundary (fig. 13). Artificial boundaries were used for the model because using the boundaries of the eastern SRP aquifer would produce a model area much larger than that required for the purposes of this study and would include more area with little available information. Artificial boundaries were located (1) to include within the model area the part of the eastern SRP aquifer containing detectable concentrations of contaminants derived from wastewater discharged at the INL, and (2) in areas where information was available to define and characterize the boundary and flows across the boundary. 

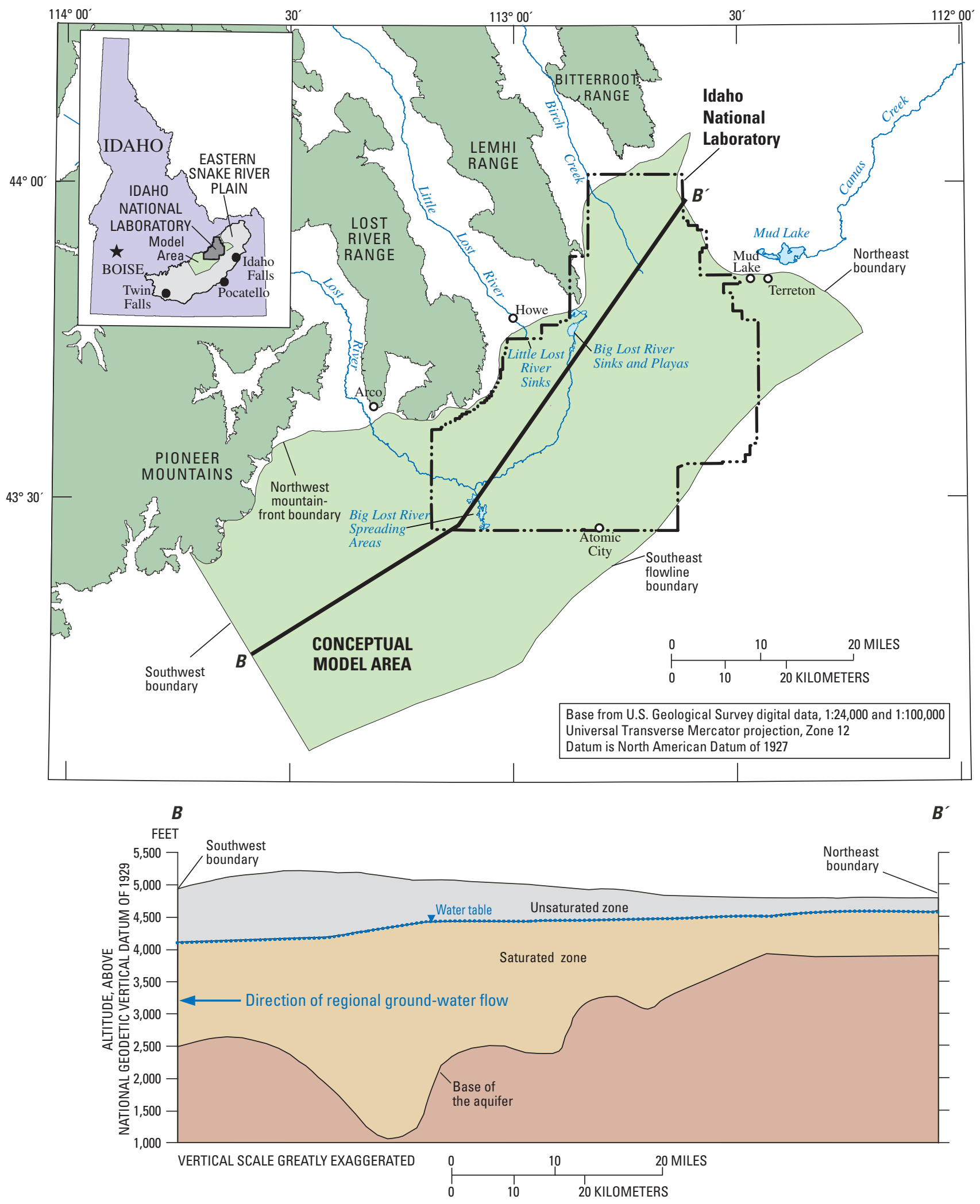

Figure 13. Location of the model boundaries, Idaho National Laboratory and vicinity, Idaho. 


\section{Physical Boundaries}

The water-table boundary is represented by the contact between the unsaturated zone and the saturated zone. The thickness of the unsaturated zone ranges from about 200 to $1,000 \mathrm{ft}$ (fig. 10). The altitude of the water table decreases about $500 \mathrm{ft}$ across the length of the model area, from 4,600 ft at the northeast boundary of the model to about 4,100 ft at the southwest boundary of the model (fig. 9). The watertable boundary rises or declines in response to climatic- or irrigation-induced changes in recharge to the aquifer.

The base of the aquifer is interpreted as the contact between the older rocks and the overlying intermediate-age rocks. This contact generally is characterized by an abrupt downward increase in intensely altered basalt and interbedded sediment (Mann, 1986, p. 4-5; Whitehead, 1992, p. 10; Morse and McCurry, 1997 p. 6-7; Anderson and Liszewski, 1997, p. 28). In seven wells and coreholes, this contact also coincides with a change from convective-dominated to conductive-dominated heat flow and a decrease in hydraulic conductivity and porosity (Mann, 1986, p. 21; Morse and McCurry, 1997, p. 6-7; Welhan and Wylie, 1997, p. 99; Morse and McCurry, 2002, p. 222; Mazurek and others, 2004). Collectively, these factors indicate that water circulation is limited in older rocks.

Direct evidence indicating the location of the base of the aquifer was limited to data from 13 deep wells and coreholes (Mann, 1986, p. 21; Whitehead, 1992, fig. 8 and pl. 6; Morse and McCurry, 1997, p. 4-7, fig. 2; Anderson and Liszewski, 1997, table 3; Mazurek and others, 2004). Morse and McCurry $(1997,2002)$ correlated the base of the aquifer with an increase in alteration of basalts and temperature gradient in six deep wells where temperature was measured (Blackwell and others, 1992). Mazurek and others (2004) made the same correlation based on data from a more recently drilled deep borehole. Morse and McCurry (1997) estimated depth to the base of the aquifer in the central part of the INL to be about 1,340 ft. Anderson and Liszewski (1997, p. 4), on the basis of stratigraphic data from 10 deep wells and coreholes in the western half of the INL, suggested that the base most likely coincides with the top of a thick and widespread layer of clay, silt, sand, and altered basalt that is consistent in age with rocks of the Glenns Ferry Formation. They reported a depth to the base of the aquifer in the western half of the INL ranging from 815 to $1,710 \mathrm{ft}$ below land surface and a saturated thickness ranging from 445 to $1,200 \mathrm{ft}$.

Indirect evidence indicating the location of the base of the aquifer included regional surface-based electrical-resistivity surveys (Whitehead, 1992, pl. 6) and regional gravity surveys (Whitehead, 1992, fig. 8). Based on surface-based electricalresistivity soundings and drillhole data, Whitehead (1986, sheet 2, section $\mathrm{H}-\mathrm{H}^{\prime}$ ) estimated that (1) depth to the base of the aquifer could exceed 3,000 ft in the eastern half of the INL, and (2) saturated thickness of the aquifer could exceed $2,500 \mathrm{ft}$ in the eastern half of the INL and 4,000 ft in the southwestern part of the model area. Whitehead (1986, sheet 2) reported saturated thickness using contour intervals of $500 \mathrm{ft}$; therefore, the uncertainty of these estimates is at least $\pm 250 \mathrm{ft}$. However, because electrical-resistivity surveys tend to overestimate basalt thickness (Zohdy, 1974, p. 32), these estimates of depth to the base of the aquifer and saturated thickness may be high.

Whitehead's (1986, sheet 2) data were used to calculate the depth to the base of the aquifer, rather than data from the 13 deep wells and coreholes, because Whitehead's data provide coverage over the entire model area. Using Whitehead's (1986, sheet 2) data for thickness of Quaternary basalt and sediment and a digital elevation model, depth to the base of the aquifer was calculated using a geographic information system. However, depth to the base of the aquifer in the area mountainward of the Big Lost River was subsequently adjusted to a lesser depth based on stratigraphic interpretations that indicate the aquifer is thinner in this area (Anderson and Liszewski, 1997, figs. 29, 30). Interpreted depth to the base of the aquifer in the model area ranges from about 700 to $4,800 \mathrm{ft}$. Depth is least near the northwest mountain-front boundary, increases to the east, and is greatest along the southeast-flowline boundary (fig. 14). A shaded relief map (fig. 15) of the contact between the intermediateage rocks of hydrogeologic unit 3 and the older rocks that form the base of the aquifer indicates that the inferred threedimensional topography along the base of the aquifer is irregular.

The northwest mountain-front boundary is defined by the edge of the mountain fronts of the Pioneer Mountains, Lost River Range, Lemhi Range, and Bitterroot Range and the mouths of the Big Lost River, Little Lost River, and Birch Creek valleys (fig. 1). This boundary coincides with part of the northwest boundary of the eastern SRP as described in the RASA study (Garabedian, 1992). Aquifer thickness along the northwest mountain-front boundary ranges from about 200 to $500 \mathrm{ft}$.

\section{Artificial Boundaries}

The northeast boundary is upgradient of the INL in an area where the hydraulic gradient increases sharply (figs. 3 and 9). The hydraulic gradient in this area ranges from 27 to $60 \mathrm{ft} / \mathrm{mi}$ and averages about $36 \mathrm{ft} / \mathrm{mi}$ (fig. 12A) (Lindholm and others, 1988). These steep gradients coincide with changes in aquifer transmissivity near Mud Lake where basalt interfingers with less transmissive layers of sediment (Crosthwaite, 1973, p. 6; Lindholm, 1996, p. 22) and probably are caused by a decrease in hydraulic conductivity associated with these finegrained sediments (Nace and others, 1959, p. 151-2; Mundorff and others, 1964, p. 133; Lindholm and others, 1988). This low-transmissivity zone impedes horizontal flow (Crosthwaite, 1973, p. 11; Spinazola, 1994, p. 29) and results in a large downward vertical component of flow. Aquifer thickness along the northeast boundary ranges from about 500 to $800 \mathrm{ft}$. 


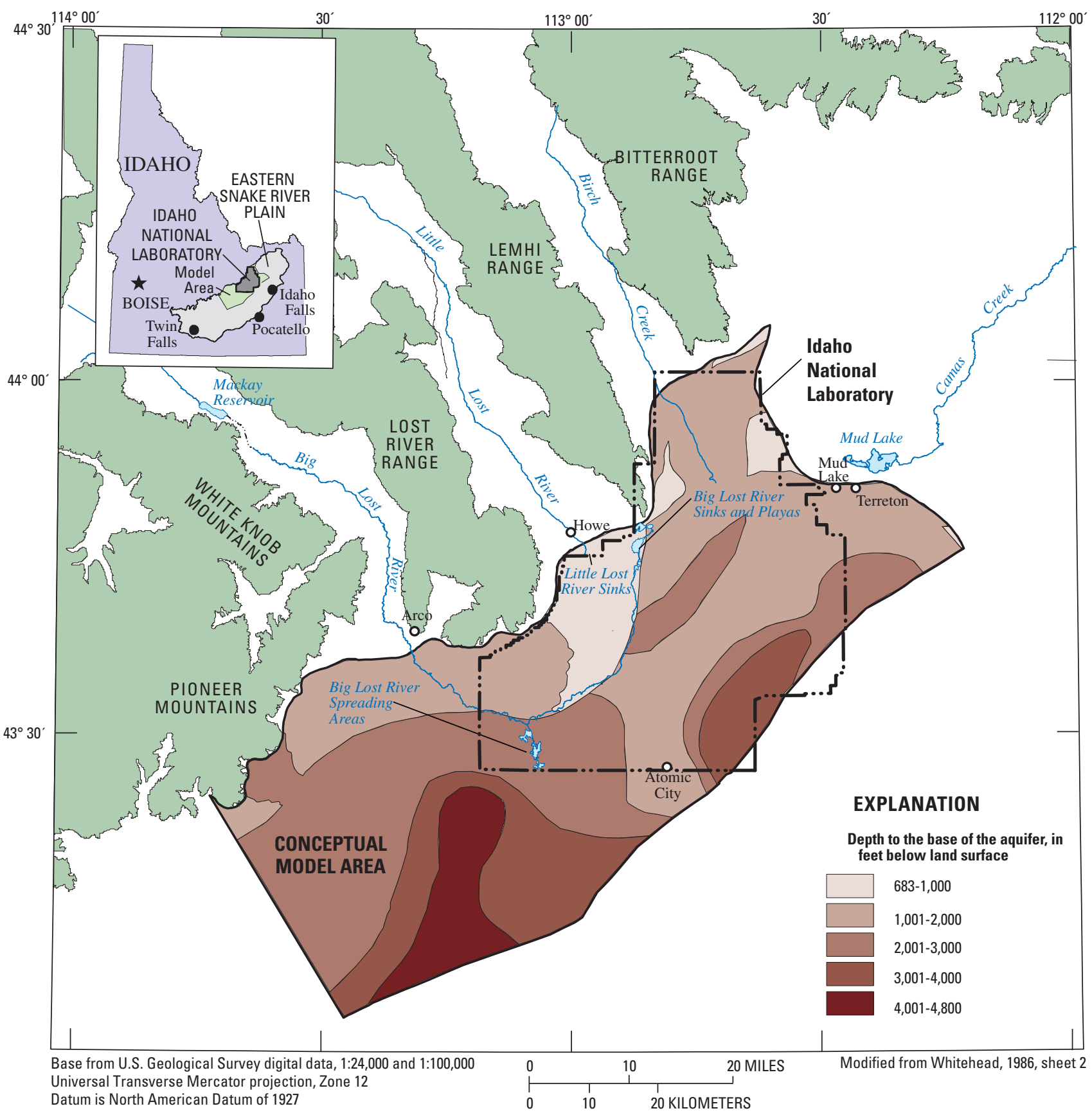

Figure 14. Depth to the base of the eastern Snake River Plain aquifer in the model area, Idaho National Laboratory and vicinity, Idaho. 


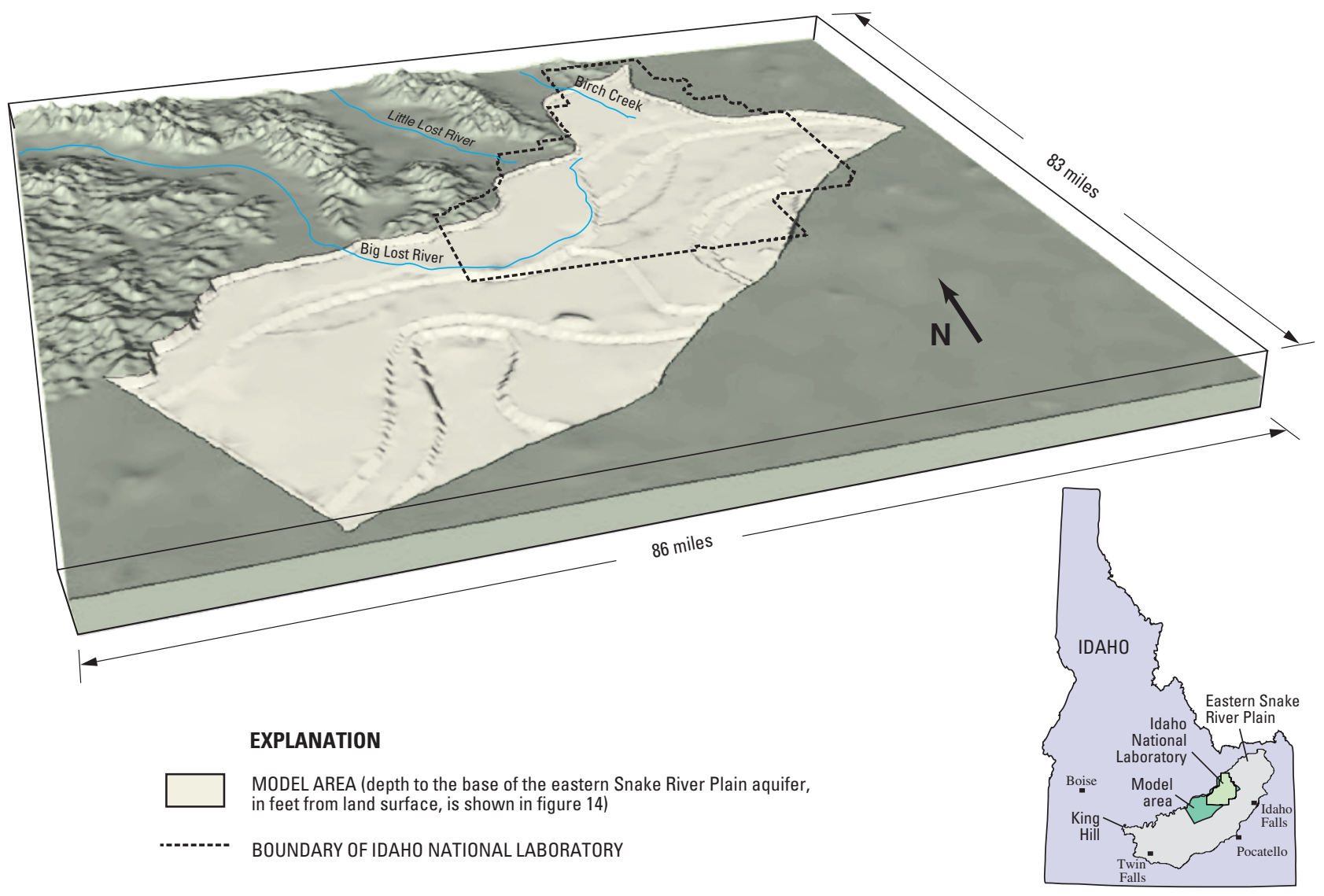

Figure 15. Contact between the intermediate-age rocks of hydrogeologic unit 3 and the older rocks underlying the base of the eastern Snake River Plain aquifer beneath the model area, Idaho National Laboratory and vicinity, Idaho.

The southeast-flowline boundary is near the central axis of the eastern SRP (figs. 3 and $\underline{13}$ ), and the aquifer thickness along this boundary ranges from about 800 to $4,000 \mathrm{ft}$. The boundary is represented as a southwest trending flowline derived from pathline analyses (Ackerman, 1995) of the steady-state, three-layer RASA model (Garabedian, 1992). Ackerman's model computed three-dimensional pathlines that originated as particles introduced near the water table. Particles introduced at the water table upgradient of the model area followed nearly parallel pathlines along the model area's southeastern boundary (Ackerman, 1995, fig. 8). These simulations showed that, although most flow is horizontal and contained in the uppermost $500 \mathrm{ft}$ of the aquifer, particles that penetrate deeper into the aquifer also follow nearly parallel pathlines along this boundary. The sustained parallelism of these pathlines implies that little or no lateral divergence of flow occurs at depth along the central axis of the eastern SRP aquifer (fig. 3) east of the INL. Projections of pathlines to the water table indicated that particle pathlines at depth are nearly parallel to flowlines oriented perpendicular to water-table contours in the central part and along the central axis of the eastern SRP aquifer east of the INL (Robertson and others, 1974; Barraclough and Jensen, 1976; Barraclough and others, 1981; Lewis and Jensen, 1985; Pittman and others, 1988; Orr and Cecil, 1991; Ackerman, 1995, fig. 8; and Bartholomay and others, 1995). Therefore, the pathline representing the southeast boundary of the model area can be approximated as a flowline in a vertical subsurface projection.

The southwest boundary is located so the model includes areas of the aquifer downgradient of where contaminants were detected and attributed to wastewater discharged at the INL (fig. 2). No physical hydrologic features are present that could be used as a model boundary in this area. Consequently, an artificial boundary was located along a gridline from the RASA model (fig. 16) about $25 \mathrm{mi}$ downgradient of the southwestern extent of chlorine-36 $\left({ }^{36} \mathrm{Cl}\right)$ detections in the aquifer (Beasley, 1995, appendix 2). Few wells penetrate the aquifer in this area, so the subsurface geology and hydraulic properties along the southwest boundary are not well known. Aquifer thickness along this boundary ranges from about 500 to $3,000 \mathrm{ft}$. 


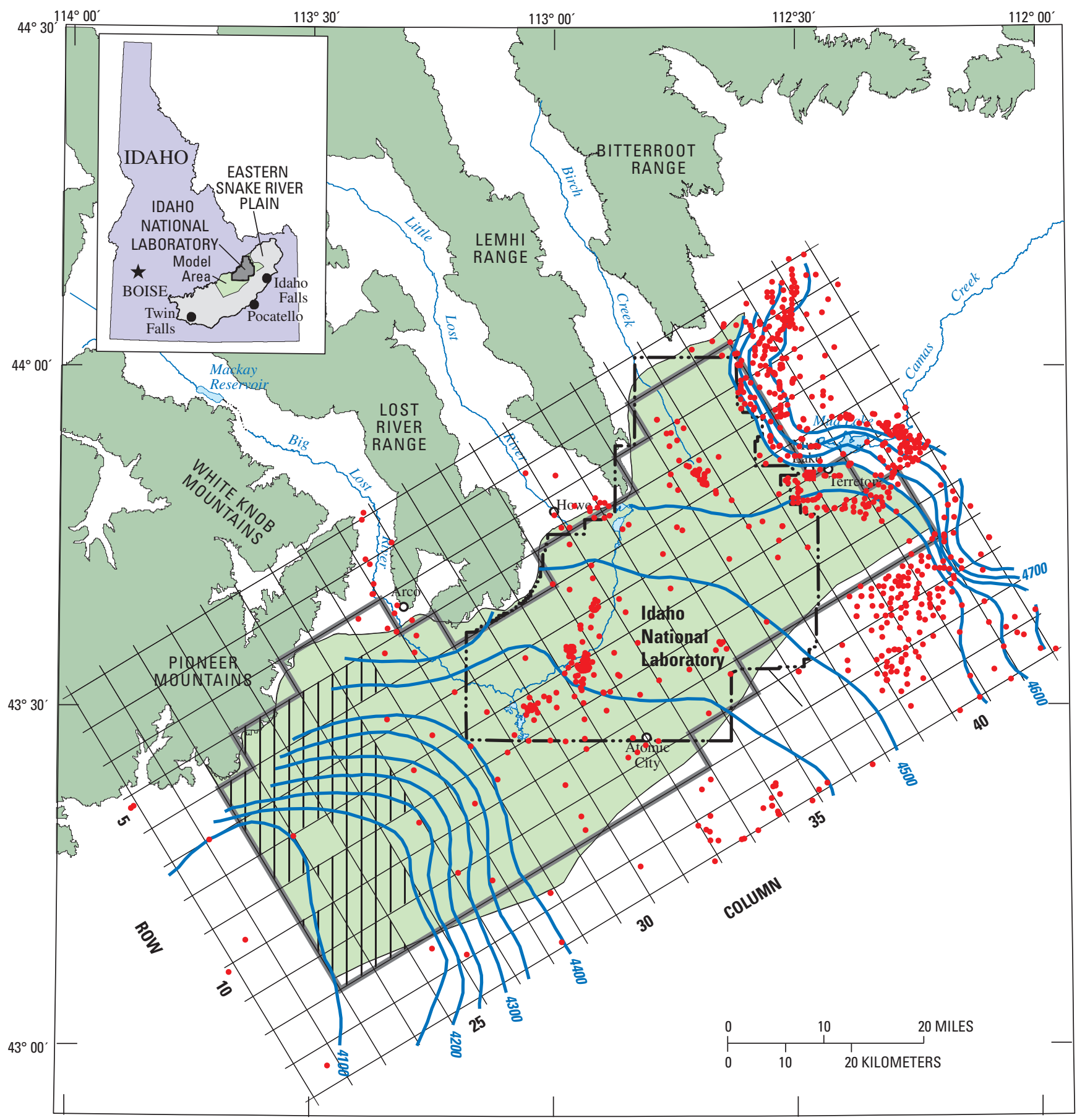

Base from U.S. Geological Survey digital data, 1:24,000 and 1:100,000 Universal Transverse Mercator projection, Zone 12

Datum is North American Datum of 1927

\section{EXPLANATION}
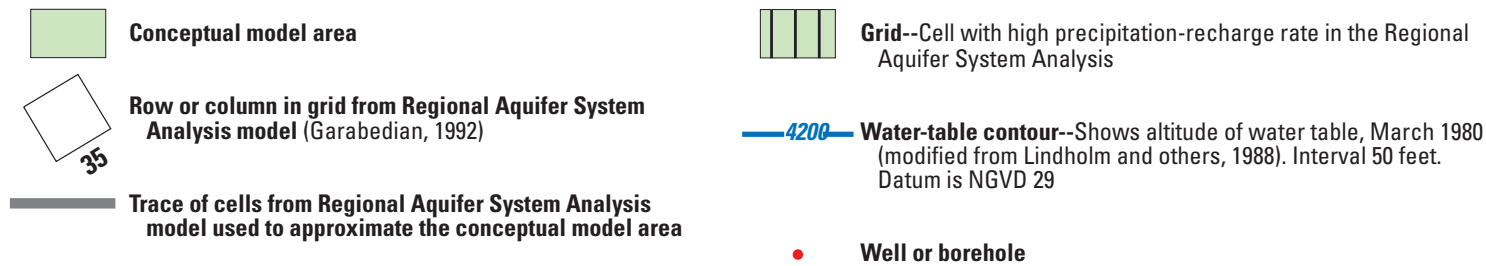

Figure 16. Regional Aquifer System Analysis model grid used to approximate the northeast, southeast-flowline, and southwest boundaries of the conceptual model, Idaho National Laboratory and vicinity, Idaho. 


\section{Inflows, Outflows, and Fluxes Across Model Boundaries}

Inflows, outflows, and fluxes (flow per unit area) across the model boundaries (fig. 17 and table 4) were estimated on the basis of hydrologic data collected and interpretive studies done during the past 50 years and application of Darcy's Law to physical and hydrologic features along these boundaries. The past 50 years represent a time when the hydrologic conditions of the system were relatively stable compared with conditions in the first 50 years of the twentieth century, when changes in irrigation practices, climatic variations, and surface-water diversions placed greater stresses on the system (Garabedian, 1992, p. 31, 50). Inflows and outflows across model boundaries were conceptualized as spatially uniform or nonuniform, and as temporally constant or variable (table 4). These boundary characteristics represent varying degrees of simplification that reflect (1) physical features of the boundary (for example, the tributary-valleys along the northwest mountain-front boundary), (2) hydraulic features of the boundary (for example, the water-table gradients along the northeast boundary), (3) data limitations that do not justify characterization of flow across the boundary in greater detail (for example, the base of the aquifer), (4) proximity of flow across the boundary to areas of known aquifer contamination (for example, industrial wastewater return flows), and (5) the magnitude and relative importance of the boundary flux to contaminant transport (for example, precipitation and streamflow-infiltration recharge).
Streamflow infiltration and underflow from the tributary streams and valleys (Big Lost River, Little Lost River, and Birch Creek), respectively, provide recharge to the eastern SRP aquifer. In the conceptual model, infiltration recharge from the tributary streams was treated as flow across the water-table boundary, and underflow from the tributary valleys was treated as flow across the northwest mountain-front boundary.

\section{Water-Table Boundary}

Inflows and outflows across the water-table boundary (fig. 13) were treated implicitly ${ }^{1}$ in the conceptual model and comprise five components: (1) diffuse areal precipitation recharge; (2) infiltration recharge from streams originating in tributary valleys; (3) ground-water withdrawals for irrigation and industrial use; (4) wastewater return flows; (5) and irrigation-infiltration recharge. Release of water from storage, which is an internal flow, is discussed with flows across the water-table boundary. Individual flow components may be small or zero during some periods, but may be important because of their proximity to wastewater discharged in the eastern SRP aquifer at the INL.

\footnotetext{
${ }^{1}$ Flow through the unsaturated zone is treated as time-averaged (annual and seasonal) net-infiltration recharge to the aquifer. Downward flow in response to changes in the saturation-matric potential and saturation-hydraulic conductivity relations embodied in the Richards' equation for unsaturated flow is assumed to be included in inflow components of the water budget that are areally uniform (precipitation) or areally nonuniform (streamflow infiltration, industrial wastewater return flow, and irrigation infiltration) and temporally constant (precipitation) or temporally variable (streamflow infiltration, industrial wastewater return flow, and irrigation return flow). Typical unsaturated-zone flow processes, such as moisture depletion from evapotranspiration, downward percolation and lateral redistribution, wetting and drying, and perching, are not treated as distinct flow processes.
}

Table 4. Summary of conceptual model boundary characteristics and estimated 1980 inflows and outflows, Idaho National Laboratory and vicinity, Idaho.

[Abbreviations: $\mathrm{ft}^{3} / \mathrm{s}$, cubic foot per second]

\begin{tabular}{|c|c|c|c|c|}
\hline \multirow{2}{*}{ Boundary } & \multicolumn{3}{|c|}{ Boundary characteristics } & \multirow{2}{*}{$\begin{array}{l}\text { Estimated } 1980 \\
\text { flow }\left(\mathrm{ft}^{3} / \mathrm{s}\right)\end{array}$} \\
\hline & Type & Spatial & Temporal & \\
\hline \multicolumn{5}{|l|}{ Physical Boundaries } \\
\hline \multicolumn{5}{|l|}{ Water-table boundary } \\
\hline Precipitation recharge & Inflow & Uniform & Constant & 70 \\
\hline Streamflow-infiltration recharge & Inflow & Nonuniform & Variable & 95 \\
\hline Ground-water withdrawals & Outflow & Nonuniform & Variable & 45 \\
\hline Industrial wastewater return & Inflow & Nonuniform & Variable & 6 \\
\hline Irrigation infiltration & Inflow & Nonuniform & Variable & 24 \\
\hline Change in storage & Inflow & Uniform & Variable & 80 \\
\hline Base of the aquifer & Noflow & Uniform & Constant & 44 \\
\hline Northwest mountain-front boundary & Inflow & Nonuniform & Constant & 695 \\
\hline \multicolumn{5}{|l|}{ Artificial boundaries } \\
\hline Northeast boundary & Inflow & Nonuniform & Constant & 1,225 \\
\hline Southeast-flowline boundary & Noflow & Uniform & Constant & 0 \\
\hline Southwest boundary & Outflow & Nonuniform & Variable & 2,037 \\
\hline
\end{tabular}




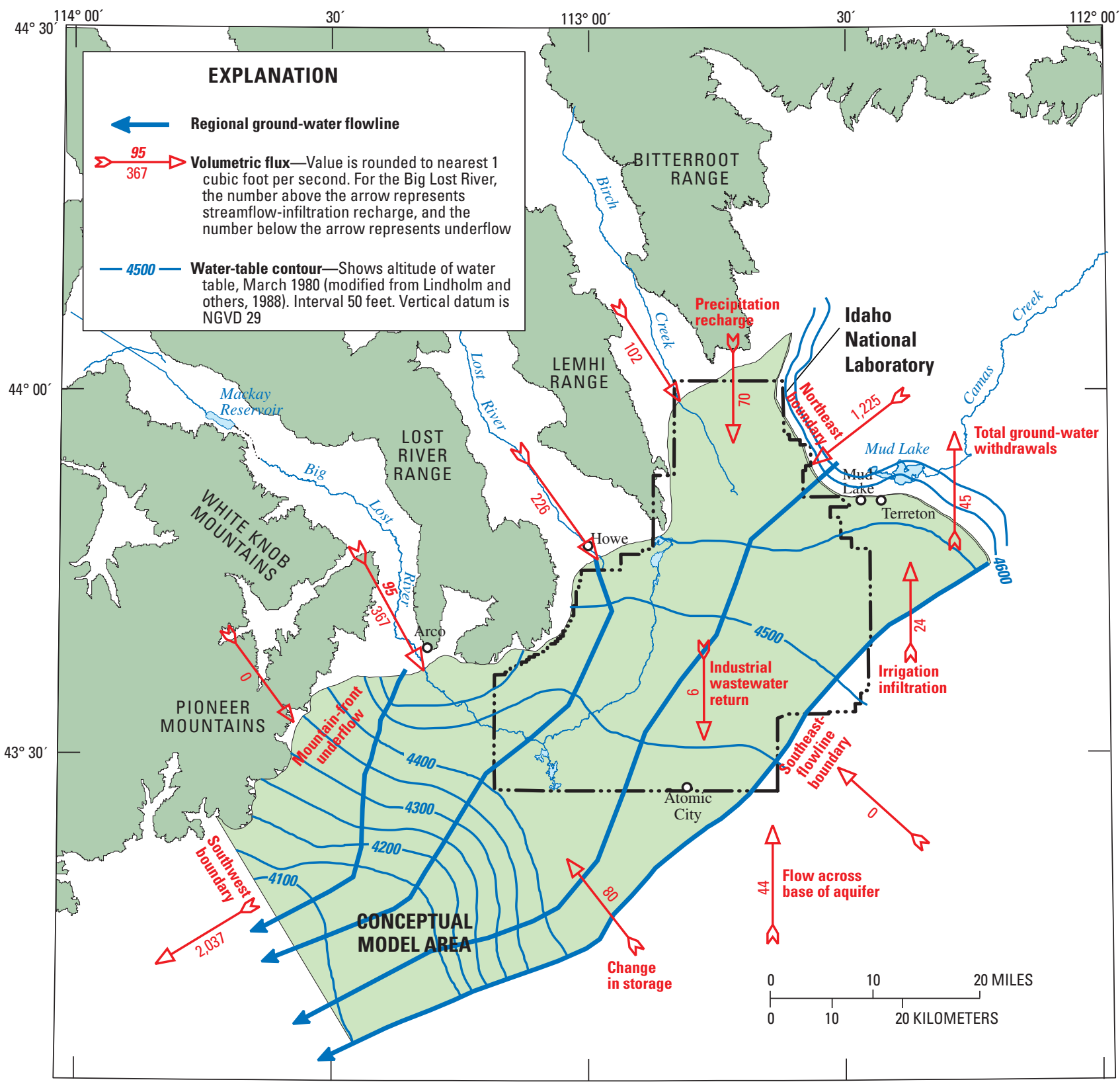

Base from U.S. Geological Survey digital data, 1:24,000 and 1:100,000

Universal Transverse Mercator projection, Zone 12

Datum is North American Datum of 1927

Figure 17. Generalized ground-water budget components for the model area, 1980, Idaho National Laboratory and vicinity, Idaho. 


\section{Precipitation Recharge}

Although the quantity, temporal variability, and spatial distribution of precipitation recharge in the model area are not well defined, studies indicate that the net effect of this recharge probably is small and is of less importance than that of other recharge sources. The effect of precipitation recharge in the model area has not been discernable in water-level measurements. Mundorff and others (1964, p. 184) estimated precipitation recharge for two areas of different soil cover in the model area. Precipitation recharge was $0.02 \mathrm{ft} / \mathrm{yr}$ in the central part of the eastern SRP. Precipitation recharge was $0.3 \mathrm{ft} / \mathrm{yr}$ near Craters of the Moon National Monument (fig. 1), where precipitation is greater and fractured basalt and rubble cover the surface. Kjelstrom (1995, p. 11) reported an average precipitation recharge of $0.08 \mathrm{ft} / \mathrm{yr}$ based on a basinwide water budget for the eastern SRP. Based on ${ }^{36} \mathrm{Cl}$ and tritium $\left({ }^{3} \mathrm{H}\right)$ profiles and neutron logging, Cecil and others (1992, p. 713) estimated that net precipitation recharge at the INL ranges from 2 to 5 percent of mean annual precipitation. Precipitation at the INL is about $0.7 \mathrm{ft} / \mathrm{yr}$ (Clawson and others, 1989, tables D-1 and D-2; Goodell, 1988, fig. 5), and 2 to 5 percent of this value would be from 0.01 to $0.04 \mathrm{ft} / \mathrm{yr}$. Using a maximum recharge rate of $0.04 \mathrm{ft} / \mathrm{yr}$ for the $1,940 \mathrm{mi}^{2}$ of the model area, maximum mean annual precipitation recharge across the water table is about $70 \mathrm{ft}^{3} / \mathrm{s}$. A uniform distribution of $70 \mathrm{ft}^{3} / \mathrm{s}$ of precipitation recharge over the model area would result in an infiltration flux of about $0.04\left(\mathrm{ft}^{3} / \mathrm{s}\right) / \mathrm{mi}^{2}$. This very low areal flux indicates that the effect of precipitation recharge on ground-water flow directions and velocities is probably very small. In areas where precipitation accumulates as runoff into small, closed basins, numerous sedimentary interbeds in the thick, unsaturated zone (200-1,000 ft) serve to intercept and laterally redistribute downward percolation. This redistribution tends to offset effects of local runoff accumulation and maintains an approximately uniform and constant rate of recharge to the aquifer.

\section{Streamflow-Infiltration Recharge}

Streamflow onto the INL is intermittent and nearly all streamflow infiltrates through the thick, unsaturated zone and recharges the eastern SRP aquifer. Streams tributary to the eastern SRP near the INL originate in mountain ranges north and west of the model area (fig. 15) and include the Big Lost River, the Little Lost River, and Birch Creek. Routine streamflow measurements were made by the USGS at several streamflow-gaging stations on these streams for more than 50 years.

\section{Big Lost River}

Because of its large flux and proximity to known sources and areas of contamination in the aquifer, streamflowinfiltration recharge from the Big Lost River is considered more significant to contaminant transport than the other components of inflow across the water-table boundary. During years with sufficient precipitation, the Big Lost River flows onto the eastern SRP near Arco and terminates on the INL in a series of four playas southwest of TAN (Kjelstrom and Berenbrock, 1996). Water from the river is stored in Mackay Reservoir (capacity 44,370 acre-ft; Bennett, 1990) (fig. 1), about 40 mi upstream of the INL. In most years, much of the water in the river downstream of the reservoir is diverted for irrigation or infiltrates through the riverbed before reaching Arco (Kjelstrom and Berenbrock, 1996). The average annual streamflow of the Big Lost River near Arco for the period of record available between 1946 and 2003 was $95 \mathrm{ft}^{3} / \mathrm{s}$ (fig. 18, gaging station 13132500); (Brennan and others, 2004, p. 196). However, streamflow fluctuates greatly in response to shortterm (3 to 8 years) climate cycles. During dry climate cycles, streamflow in the Big Lost River near Arco frequently is zero (fig. 18). In 1984, however, during a wet climate cycle, the mean annual streamflow at the gaging station near Arco was $488 \mathrm{ft}^{3} / \mathrm{s}$ (fig. 18), or more than 20 percent of the estimated 1980 outflow across the southwest boundary of the model area (table 4).

Flow from the Big Lost River is diverted to spreading areas southwest of the RWMC near the southwest boundary of the INL (fig. 1) to prevent flooding of site facilities. The spreading areas were constructed in 1958, first used in 1965, and enlarged in 1984 (Bennett, 1990, p. 6). Between 1965 and 2002, about 47 percent $\left(48 \mathrm{ft}^{3} / \mathrm{s}\right.$, table 5) of the streamflow at the INL diversion [(103 $\mathrm{ft}^{3} / \mathrm{s}$, table 5$)$, estimated from the combined streamflow for gaging stations INL diversion at head near Arco (gaging station 13132513, fig. 1) and Big Lost River below diversion near Arco (gaging station 13132520, fig. 1)] was diverted to the spreading areas. Because the spreading areas were used for flood control, during wet climate cycles an even larger percentage of streamflow was diverted to the spreading areas. For instance, in 1984, the year of highest recorded flows, about 83 percent $\left(379 \mathrm{ft}^{3} / \mathrm{s}\right.$, fig. 18 , and table 5) of streamflow at the INL diversion was diverted to the spreading areas. The use of the spreading areas has changed the location of much of the streamflow-infiltration recharge to the aquifer. Before 1965, the Big Lost River recharged mostly in the sinks and playas in the west-central part of the INL; currently, when flow extends onto the plain, much of it recharges in the spreading areas near the southwest boundary of the INL. 

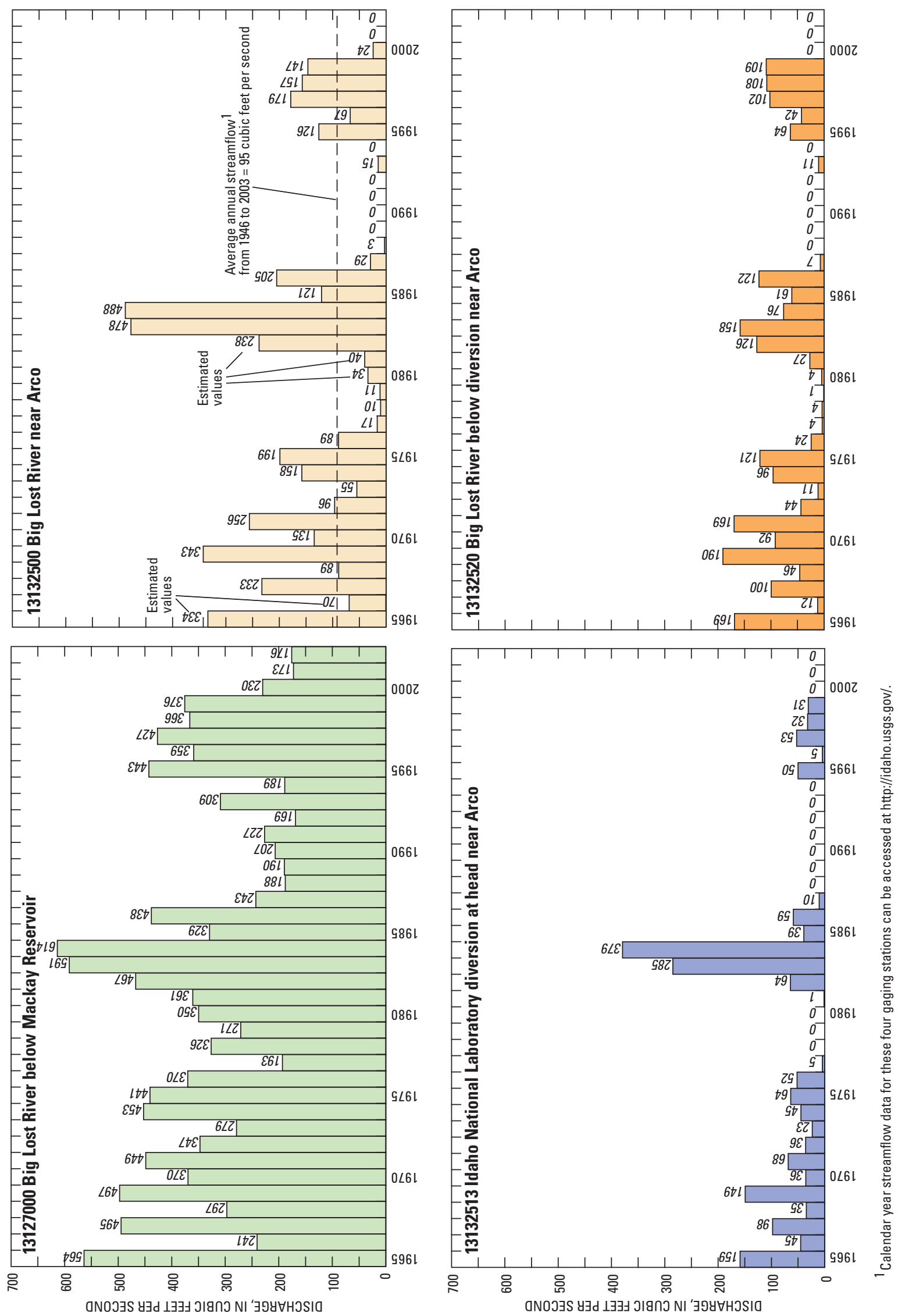

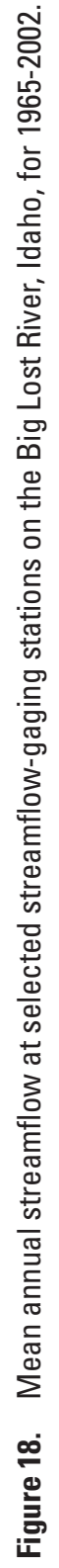


Table 5. Summary of streamflow at two streamflow-gaging stations on the Big Lost River, Idaho.

[Location of streamflow-gaging stations (for example 13132513) shown in figure 1. Average annual streamflow: Calendar year data. Streamflow data may be accessed at http://idaho.usgs.gov/. Streamflow data for streamflowgaging stations not on the website are from Bennett, 1990, tables 4 and 6. Abbreviations: $\mathrm{ft}^{3} / \mathrm{s}$, cubic feet per second; INL, Idaho National Laboratory]

\begin{tabular}{ccc}
\hline \multirow{2}{*}{ Streamflow-gaging station } & \multicolumn{2}{c}{$\begin{array}{c}\text { Average annual streamflow } \\
\left(\mathbf{f t}^{3} / \mathbf{s}\right) \text { for } \mathbf{1 9 6 5} \text { to } \mathbf{2 0 0 2}\end{array}$} \\
\cline { 2 - 3 } & Average & Maximum \\
\hline $\begin{array}{c}\text { 13132513, INL diversion at head } \\
\text { near Arco }\end{array}$ & 48 & $379(1984)$ \\
$\begin{array}{c}\text { 13132520, Big Lost River below } \\
\text { diversion near Arco }\end{array}$ & 55 & $190(1969)$ \\
$\begin{array}{c}\text { Combined streamflow at gaging } \\
\text { stations 13132513 and 13132520 }\end{array}$ & 103 & $455(1984)$ \\
\hline
\end{tabular}

Streamflow onto the INL is spatially concentrated in the channel, sinks, playas, and spreading areas (about $5 \mathrm{mi}^{2}$ total) (fig. 1). Infiltration losses from the river channel were estimated to be from about 1 to $4\left(\mathrm{ft}^{3} / \mathrm{s}\right) / \mathrm{mi}$ between Arco and the Big Lost River Sinks to as much as $28\left(\mathrm{ft}^{3} / \mathrm{s}\right) / \mathrm{mi}$ from the Big Lost River Sinks (Bennett, 1990, p. 24 and 26). Infiltration and evaporation rates from the Big Lost River playas were estimated to be 0.16 to $0.37 \mathrm{ft} / \mathrm{d}$ and 0.01 to $0.02 \mathrm{ft} / \mathrm{d}$, respectively, and infiltration rates from Big Lost River spreading areas A and B were estimated to be 0.7 and $2.6 \mathrm{ft} / \mathrm{d}$, respectively (Barraclough and others, 1967, p. 24). Owing to the much larger rates of infiltration than evaporation, all streamflow in the model area was assumed to infiltrate to the aquifer.

Large amounts of streamflow during wet climate cycles provide a source of episodic streamflow-infiltration recharge to the aquifer. Average infiltration flux from streamflow is about $20\left(\mathrm{ft}^{3} / \mathrm{s}\right) / \mathrm{mi}^{2}$, which is more than two orders of magnitude larger than precipitation recharge per unit area. However, during 1984, a year of record-high diversions to the spreading areas, average infiltration flux at the spreading areas was $170\left(\mathrm{ft}^{3} / \mathrm{s}\right) / \mathrm{mi}^{2}$ and monthly infiltration fluxes ranged from about 80 to about $360\left(\mathrm{ft}^{3} / \mathrm{s}\right) / \mathrm{mi}^{2}$ [calculated using mean monthly streamflow to the spreading areas (Bennett, 1990, table 4) and a combined area for spreading areas A, B, C, and D of $2.3 \mathrm{mi}^{2}$ ]. Maximum monthly infiltration flux was nearly four orders of magnitude larger than precipitation recharge per unit area.
Little Lost River

Data were not adequate to estimate infiltration recharge from the Little Lost River to the model area; however, most streamflow either infiltrates or is diverted for irrigation upstream of the INL (Kjelstrom and Berenbrock, 1996, p. 3). When the Little Lost River flows onto the eastern SRP, it terminates in an area commonly referred to as the Little Lost River Sinks, near Howe, just east of the northwest mountainfront boundary of the model area (fig. 1). Stone and others (1992, p. 20-21) reported a mean annual streamflow of $77 \mathrm{ft}^{3} / \mathrm{s}$ for the combined periods of record 1941-81 and 1986-90 at a streamflow-gaging station on the Little Lost River about $7 \mathrm{mi}$ northwest of Howe (streamflow-gaging station 13119000 , fig. 1).

\section{Birch Creek}

The amount of infiltration from Birch Creek streamflow to the eastern SRP aquifer is not well documented because streamflow-gaging stations upstream of the INL boundary were discontinued or operated intermittently (Kjelstrom and Berenbrock, 1996, p. 7-8). Flow from Birch Creek is diverted upgradient of the model area to a hydroelectric power-generating facility several miles east of Birch Creek. Return flows as large as $46 \mathrm{ft}^{3} / \mathrm{s}$ from the power facility (Ted S. Sorenson, Sorenson Engineering, written commun., March 2001) are diverted to the northeast for irrigation use for 6 months each year. During the nonirrigation season, this water flows onto the northeastern part of the INL, where it may infiltrate to the aquifer through diversion channels and gravel pits northwest of TAN (Kjelstrom and Berenbrock, 1996, p. 5). No flow has reached the Birch Creek Sinks near TAN since 1969, when accumulation of water in the playas prompted construction of channels to divert water away from TAN (Kjelstrom and Berenbrock, 1996, p. 5).

\section{Ground-Water Withdrawals, Wastewater Return Flows, and Irrigation-Infiltration Recharge}

Total ground-water withdrawals and industrial wastewater return flows at the INL in 1980 were 45 and $6 \mathrm{ft}^{3} / \mathrm{s}$, respectively (fig. 17, table 4). Irrigation-infiltration recharge in the model area was estimated at about $24 \mathrm{ft}^{3} / \mathrm{s}$. Ground-water withdrawals in the model area include those for industrial use at onsite facilities and those for irrigation use offsite. Industrial wastewater return flows include wastewater discharged in (1) disposal ponds or ditches, where it infiltrates into the unsaturated zone and the aquifer, and (2) injection wells completed in the aquifer. 
Industrial ground-water withdrawals and wastewater return flows ranged from zero before the INL was established to a maximum in 1974 of about $12 \mathrm{ft}^{3} / \mathrm{s}$ for withdrawals and $7.3 \mathrm{ft}^{3} / \mathrm{s}$ for return flows (White, 1975). The volume of industrial ground-water withdrawals from the aquifer and wastewater discharged in infiltration ponds and wells varied over the years in response to the amount of industrial activity at INL facilities and changes in wastewater-disposal methods (Appendix A). In 1980, total industrial groundwater withdrawals at the INL were about $8.2 \mathrm{ft}^{3} / \mathrm{s}$, the volume of wastewater discharged to ponds and ditches was about $2.5 \mathrm{ft}^{3} / \mathrm{s}$, and the volume of wastewater discharged to injection wells was about $3.4 \mathrm{ft}^{3} / \mathrm{s}$ (Batchelder, 1981). Local effects of these withdrawals and returns at INL facilities were not expected to have long-term effects on aquifer response beneath the central part of the INL; however, withdrawals and returns at TRA and INTEC could have significant short-term effects on contaminant migration. Most contaminants in the aquifer beneath the INL originate at these two facilities and more than 50 percent of industrial ground-water withdrawals and 50 percent of industrial wastewater returns were pumped from or injected into the eastern SRP aquifer at these two facilities.

Ground-water withdrawals for irrigation increased substantially during the 1940s and continued to increase until the 1970s (Kjelstrom, 1995, p. 5). For 1980, estimated irrigation withdrawals in the model area are $37 \mathrm{ft}^{3} / \mathrm{s}$. Ground water used for irrigation in the model area is withdrawn from the aquifer primarily near Mud Lake, but smaller quantities also are withdrawn near Howe (fig. 1) (Garabedian, 1992, pl. 3). Spinazola (1994, p. 33-38) calculated withdrawals near Mud Lake based on electrical-power-consumption records, irrigation-system characteristics, and hydrologic measurements made between 1983 and 1990, and determined that ground-water withdrawals for irrigation in the Mud Lake area in 1983 (similar to those in 1980) were about $31 \mathrm{ft}^{3} / \mathrm{s}$. Based on estimates of irrigated acreage (DeWayne McAndrew, U.S. Bureau of Reclamation, written commun., 1996) and the volume of water used per acre in the Mud Lake area, an annual average of about $6 \mathrm{ft}^{3} / \mathrm{s}$ is withdrawn for irrigation near Howe.

Estimates of irrigation-infiltration fluxes for the SRP were reported by Goodell (1988) and Spinazola (1994). Goodell (1988, p. 48, table 15) estimated average infiltration fluxes for ground- and surface-water irrigation for the whole SRP to be 0.62 and $4.1\left(\mathrm{ft}^{3} / \mathrm{s}\right) / \mathrm{mi}^{2}$, respectively. The infiltration flux for surface-water irrigation estimated by Goodell (1988, p. 48, table 15) includes conveyance losses between points of withdrawal and application that are outside the model area. Spinazola (1994, p. 29-33, fig. 38) estimated infiltration fluxes at and north of the model area to be $0.15\left(\mathrm{ft}^{3} / \mathrm{s}\right) / \mathrm{mi}^{2}$ from sprinkler-applied irrigation (primarily from ground-water sources) and $0.71\left(\mathrm{ft}^{3} / \mathrm{s}\right) / \mathrm{mi}^{2}$ from ditch-applied irrigation (from surface-water and diverted ground-water sources). Spinazola's (1994) estimates did not have to be adjusted for conveyance losses, which were estimated separately from irrigation-infiltration fluxes, and included estimates of consumptive use for the location where irrigation was applied. Using a geographic-information-system coverage of irrigated acreage derived from 1987 aerial photographs and field checked in 1992 (DeWayne McAndrew, U.S. Bureau of Reclamation, written commun., 1996), about 40 and $26 \mathrm{mi}^{2}$ of the model area was sprinkler- and ditch-irrigated land, respectively. Based on these estimates of irrigated areas and Spinazola's (1994) estimates of irrigation-infiltration fluxes, about $24 \mathrm{ft}^{3} / \mathrm{s}$ of irrigation-infiltration recharged to the model area.

\section{Release of Water from Storage}

Release of water from storage in the model area for 1980 was estimated using measured changes in water levels from October 1979 to October 1980 (Garabedian, 1986, pl. 1D). Using RASA derived storage coefficients ranging from 0.05 to 0.2 , the calculated net gain to the aquifer from a decrease in storage during this period was 60 to $240 \mathrm{ft}^{3} / \mathrm{s}$. Using storage coefficients of 0.1 for areas dominated by basalt and 0.2 for areas dominated by sediment, the net gain to the aquifer from a decrease in storage during this period was $80 \mathrm{ft}^{3} / \mathrm{s}$.

\section{Base of the Aquifer}

Because of its low flux and distance from known areas of contamination in the aquifer, the base of the aquifer, for purposes of contaminant transport modeling, can be treated as a no-flow boundary. Upward flow across the base of the aquifer was estimated to be about $44 \mathrm{ft}^{3} / \mathrm{s}$ based on data from a few wells that penetrate the base of the aquifer. Temperature data from six deep boreholes indicate that the thermal gradient across the base of the aquifer changes from convectivedominated heat flow in the aquifer to conductive-dominated heat flow in the rocks below the aquifer (Morse and McCurry, 2002 , p. 215). This change in thermal gradient implies that flow across this boundary is small. Mann (1986, p. 22) estimated inflow to the aquifer at the INL from underlying rocks to be $20 \mathrm{ft}^{3} / \mathrm{s}$ on the basis of data from a 10,365-ft-deep test hole drilled at the INL. These estimates were based on the steepest vertical gradients measured at the INL. Extrapolation of that estimate to the $1,940 \mathrm{mi}^{2}$ of the model area indicates an inflow of about $44 \mathrm{ft}^{3} / \mathrm{s}$ or a flux of about $0.02\left(\mathrm{ft}^{3} / \mathrm{s}\right) /$ $\mathrm{mi}^{2}$ - or about half the flux estimate for precipitation recharge, $0.04\left(\mathrm{ft}^{3} / \mathrm{s}\right) / \mathrm{mi}^{2}$.

\section{Northwest Mountain-Front Boundary}

All inflows across the northwest mountain-front boundary, conceptualized as nonuniform and constant, consist of underflow from alluvial aquifers in the tributary valleys of the Big Lost River (367 $\left.\mathrm{ft}^{3} / \mathrm{s}\right)$, Little Lost River $\left(226 \mathrm{ft}^{3} / \mathrm{s}\right)$, and Birch Creek (102 ft $\left.\mathrm{ft}^{3} / \mathrm{s}\right)$. Because no estimates of underflow from the Paleozoic carbonate rocks along the mountain fronts were available, and the contribution from mountain fronts to underflow across the boundary was assumed to be small, the mountain fronts were treated as no-flow sections 
along the northwest mountain-front boundary. Hydraulic gradients abruptly increase near the mouths of the tributary valleys along the northwest mountain-front boundary, and calculated gradients at the mouths of the Big Lost River, Little Lost River, and Birch Creek are 150, 200, and 120 ft/mi, respectively. These gradients are relatively constant because the variability of the gradients is small compared to the total change in gradients. In a study of the water resources in the Big Lost River basin, Crosthwaite and others (1970, p. 97-98) concluded that the underflow from the Big Lost River basin downstream of Arco is nearly constant each year. Mundorff and others (1964, p. 185) calculated basin yields for the Big Lost River (456 $\left.\mathrm{ft}^{3} / \mathrm{s}\right)$, Little Lost River $\left(205 \mathrm{ft}^{3} / \mathrm{s}\right)$, and Birch Creek (110 ft $\left.\mathrm{ft}^{3} / \mathrm{s}\right)$. Kjelstrom (1986) calculated mean annual basin yields for the Big Lost River, Little Lost River, and Birch Creek for water years from 1934 to 1980 of 462, 226, and $102 \mathrm{ft}^{3} / \mathrm{s}$, respectively. These values included contributions from streamflow, alluvial-valley underflow, and underflow from the rocks at the mountain fronts. Subtracting the $95 \mathrm{ft}^{3} / \mathrm{s}$ estimated average annual streamflow for the Big Lost River (Brennan and others, 2004, p. 196) from Kjelstrom's (1986) basin-yield estimate, the underflow from the Big Lost River is $367 \mathrm{ft}^{3} / \mathrm{s}$.

\section{Northeast Boundary}

Underflow across the northeast boundary from the regional aquifer, conceptualized as nonuniform and constant, was estimated as $1,225 \mathrm{ft}^{3} / \mathrm{s}$ for the model area using Darcy's Law, a hydraulic conductivity of $140 \mathrm{ft} / \mathrm{d}$ (a small value to reflect the presence of the less transmissive sediments), an average hydraulic gradient of $36 \mathrm{ft} / \mathrm{mi}$, a boundary length of $35 \mathrm{mi}$, and a saturated thickness of $600 \mathrm{ft}$. The estimate is about 20 percent smaller than the estimate of underflow across the boundary $\left(1,500 \mathrm{ft}^{3} / \mathrm{s}\right)$ summed from a flow net of the eastern SRP aquifer by Mundorff and others (1964, pl. 4), and was used for the conceptual model because it was derived from (1) more numerous and better distributed boreholes in the area, (2) a longer record of water-level measurements, and (3) more numerous measurements of transmissivity and hydraulic conductivity for the area (Ackerman, 1991, table 2; Spinazola, 1994, p. 41 and fig. 35; Bartholomay and others, 1997, table 3; Anderson and others, 1999, table 2). The average saturated thickness along the northeast boundary of the model area was estimated to be about $600 \mathrm{ft}$ on the basis of Whitehead's (1986, sheet 2) interpretation of the thickness of basalt and sediment, digital elevation models, and the 1980 potentiometric surface (Lindholm and others, 1988). Garabedian (1986, table 13) estimated transmissivity near the northeast boundary of $60,000 \mathrm{ft}^{2} / \mathrm{d}$ and Norvitch and others (1969, fig. 12) estimated 700,000 $\mathrm{ft}^{2} / \mathrm{d}$. Using the saturated thickness of $600 \mathrm{ft}$, the corresponding hydraulic conductivity ranges from 100 to about 1,000 ft/d. Using the saturated thickness of $600 \mathrm{ft}$ and transmissivity values at the northeast boundary of 100,000 $\mathrm{ft}^{2} / \mathrm{d}$ from Mundorff and others (1964, pl. 6) and less than $20,000 \mathrm{ft}^{2} / \mathrm{d}$ from Newton (1978, table 16), the corresponding hydraulic conductivities are less than 200 $\mathrm{ft} / \mathrm{d}$ and about $30 \mathrm{ft} / \mathrm{d}$, respectively. Garabedian (1992, pl. 6) estimated a range of hydraulic conductivity near the boundary of from 55 to $130 \mathrm{ft} / \mathrm{d}$. Anderson and others (1999, table 3) reported geometric means and arithmetic means for hydraulic conductivity of $140 \mathrm{ft} / \mathrm{d}$ and 1,500 ft/d, respectively.

\section{Southeast-Flowline Boundary}

The southeast-flowline boundary is treated as a noflow boundary. The boundary is represented as a flowline projected vertically to depth, and consequently flow across this boundary, conceptualized as uniform and constant, is presumed to be zero. Water-table maps constructed for the eastern SRP aquifer for 1928-30, 1956-58, and 1980 (Stearns and others, 1938; Mundorff and others, 1964; and Lindholm and others, 1988) as shown by Garabedian (1992, pl. 4) indicate that changes in water levels near the INL are spatially and temporally uniform. Consequently, flow directions along most of the southeast boundary of the model area are relatively stable, and flowlines constructed for this area should be temporally constant.

\section{Southwest Boundary}

Outflow across the southwest boundary (fig. 17) was represented as nonuniform and variable underflow to the regional aquifer and was estimated at $2,037 \mathrm{ft}^{3} / \mathrm{s}$. This value was estimated for the model area using Darcy's Law and data from previous studies, and is similar to the value, $2,000 \mathrm{ft}^{3} / \mathrm{s}$, summed for underflow across this boundary from the flow net by Mundorff and others (1964, pl. 4).

The true physical length and shape of this boundary are not well known and the water-table contours and hydraulic gradients in the area are not well defined because head definition in this part of the aquifer was limited to water-level measurements in only six wells that are from 3 to $10 \mathrm{mi}$ from the boundary. The southwest boundary was estimated to be about 24-mi long; however, water-table contours indicate that flow may not cross some sections of the boundary (Lindholm and others, 1988). Whitehead (1986, sheet 2) estimated the average saturated thickness of the aquifer in the southwestern part of the model area to be about 2,000 ft. Estimates of transmissivity in this area range from about 1,700,000 $\mathrm{ft}^{2} / \mathrm{d}$ (Norvitch and others, 1969, p. 37) to about 2,300,000 $\mathrm{ft}^{2} / \mathrm{d}$ (Mundorff and others, 1964, pl. 6). Assuming an aquifer thickness of 2,000 ft the corresponding hydraulic conductivity ranges from 850 to $1,150 \mathrm{ft} / \mathrm{d}$. Using Darcy's Law, the smallest $(850 \mathrm{ft} / \mathrm{d})$ and largest $(1,150 \mathrm{ft} / \mathrm{d})$ estimates of hydraulic conductivity, a boundary length of about $22 \mathrm{mi}$ (across which flow occurs), a hydraulic gradient of $4 \mathrm{ft} / \mathrm{mi}$ (fig. 3), and a saturated thickness of 2,000 ft, underflow across the southwest boundary ranges from 1,731 to $2,343 \mathrm{ft}^{3} / \mathrm{s}$. The average of these values, $2,037 \mathrm{ft}^{3} / \mathrm{s}$, was used in the water budget for the conceptual model. 


\section{Ground-Water Budget}

A ground-water budget was derived for the conceptual model area for calendar year 1980 from estimates of inflows and outflows across the model boundaries. A budget residual of about 7 percent between inflow and outflow results from the uncertainty in the estimates of flow across each boundary using data from different sources. These ground-water budget components were compared with components calculated for the conceptual model area using output from the RASA model (table 6) (Garabedian, 1992). Even though the conceptual model area covers only about 18 percent of the RASA model area (fig. 5), the flows calculated for the conceptual model from the RASA model were considered reasonably accurate because the RASA model was constrained by measured outflows in the Thousand Springs area (fig. 3).

\section{Ground-Water Budget for the Conceptual Model Area}

Of the inflow components of the ground-water budget for the model area, about 8 percent enters at the water table, releases from storage account for about 4 percent, upward flow across the base of the aquifer contributes about 2 percent, and about 86 percent enters as underflow along the northwest mountain-front and northeast boundaries (table 6). Of the 8 percent of the budget that enters the model area at the water table, 3 percent is by recharge from precipitation, 4 percent is from streamflow-infiltration recharge along the Big Lost River, and 1 percent is from infiltration of irrigation and industrial wastewater return flows. Underflow along the northwest mountain-front and northeast boundaries contribute 31 percent and 55 percent, respectively, of the total inflow into the model area. Flow across the southeast-flowline boundary, approximated by a pathline projected from depth to the water table (Ackerman, 1995), was designated as zero because it was represented as a flowline or noflow boundary. At the scale of the conceptual model area, this noflow boundary is an idealized approximation, but some local flow probably occurs across this boundary.

Of the outflow components of the ground-water budget for the conceptual model area, about 2 percent is from ground-water withdrawals and about 98 percent is underflow across the southwest boundary to adjacent parts of the aquifer. The ground-water withdrawals are the amount of ground water withdrawn for irrigation and industrial uses.

\section{Comparison and Analysis of the Ground-Water Budget}

For comparison purposes, a ground-water budget for the conceptual model area, which lies entirely in the RASA model area (fig. 5), was calculated using input and output from the transient three-dimensional RASA model simulations (table 6)
(Garabedian, 1992). The RASA-derived budget was calculated for the period 1976-80, a time when hydrologic conditions in the eastern SRP aquifer were relatively stable. Flow across each conceptual model boundary was calculated by tabulating flow values for each regional model cell (4 mi on a side) that most closely approximated conceptual model boundaries.

Total inflow and total outflow from the RASA-derived ground-water budget exceeded the ground-water budget estimates for the conceptual model by 14 and 23 percent, respectively (table 6). These percentage differences are relatively large. Unlike the conceptual model budget, the RASA budget was derived from a transient model simulation that, by design, precluded a budget residual because differences between inflow and outflow within every grid cell were accounted for by changes in storage. Residual in the conceptual model budget, $157 \mathrm{ft}^{3} / \mathrm{s}$ (table 6), represents the equivalent of 6 percent of the inflow and outflow components of the RASA-derived budget. To some extent, the $157 \mathrm{ft}^{3} / \mathrm{s}$ residual is a measure of the cumulative uncertainty of the inflow and outflow estimates and may account for some of the differences in the inflow $\left(311 \mathrm{ft}^{3} / \mathrm{s}\right)$ and outflow $\left(469 \mathrm{ft}^{3} / \mathrm{s}\right)$ estimates of the two water budgets.

Some of the differences in the individual inflow and outflow estimates of the two water budgets can be attributed to a combination of (1) coarse discretization of the RASA model grid, (2) interpolation errors resulting from inflow and outflow estimates that are assumed to be uniformly distributed within the RASA model grid cells and that accumulate where the grid cell faces approximating the conceptual model boundaries are offset from the grid cell faces of the RASA model (fig. 16), (3) noncompensating summation errors, particularly for estimates along the southeast boundary, which is oriented parallel to the direction of regional flow and is therefore particularly susceptible to this type of error (fig. 16), (4) hydrogeologic judgment, and (5) accounting methodology.

The $79 \mathrm{ft}^{3} / \mathrm{s}$ difference between the conceptual-model and RASA-derived estimates of outflow from groundwater withdrawals reflects accounting limitations owing to coarse discretization of the model grid. Most ground-water withdrawals for irrigation are in the Mud Lake area, north of the northeast boundary of the conceptual model. The grid cells in the RASA model that approximate the alignment of the northeast boundary of the conceptual model encompass more wells than are actually present in the conceptual model area (fig. 16) as summed from Spinazola's (1994) and McAndrew's (U.S. Bureau of Reclamation, written commun., 1996) data.

Interpolation errors were associated with estimates of underflow across the south corner of the southwest boundary of the conceptual model. Estimates of underflow across this boundary, for which data are very limited, are perhaps the least reliable of all the water-budget components. These estimates were based on application of Darcy's Law. To account for uncertainties in hydraulic conductivities, hydraulic gradients, and saturated thickness of the aquifer in the southwestern 
Table 6. Ground-water budget for the conceptual model area for 1980 and derived from the Regional Aquifer System Analysis (RASA) model of the Snake River Plain aquifer, Idaho.

[Data from sources listed in "Inflows, Outflows, and Fluxes Across Model Boundaries" section. Flow values are in cubic feet per second (ft $3 / \mathrm{s})$. Percentage rounded to nearest 1 percent; sum of inflows may not equal sum of outflows because of independent calculation of flows from various data sources, resulting in a budget residual. Values derived from RASA (Garabedian, 1992) model simulation output for a transient-state three-dimensional regional flow model for 1976-80. Symbol: $<$, less than]

\begin{tabular}{|c|c|c|c|c|}
\hline \multirow{2}{*}{ Inflow } & \multicolumn{2}{|c|}{1980 (this report) } & \multicolumn{2}{|c|}{ Derived from RASA model } \\
\hline & Flow & Percentage of total & Flow & Percentage of tota \\
\hline \multicolumn{5}{|l|}{ Water-table boundary } \\
\hline Precipitation recharge & 70 & 3 & 157 & 6 \\
\hline Big Lost River infiltration recharge & 95 & 4 & 101 & 4 \\
\hline Little Lost River infiltration recharge & 0 & 0 & 17 & 1 \\
\hline Industrial wastewater return & 6 & $<1$ & 0 & 0 \\
\hline Irrigation infiltration & 24 & 1 & 0 & 0 \\
\hline Change in storage & 80 & 4 & 145 & 6 \\
\hline Base of the aquifer & 44 & 2 & 0 & 0 \\
\hline \multicolumn{5}{|l|}{ Northwest mountain-front boundary } \\
\hline Big Lost River underflow & 367 & 16 & 366 & 15 \\
\hline Little Lost River underflow & 226 & 10 & 212 & 8 \\
\hline Birch Creek underflow & 102 & 5 & 103 & 4 \\
\hline Mountain-front underflow & 0 & 0 & 48 & 2 \\
\hline Northeast boundary & 1,225 & 55 & 1,207 & 47 \\
\hline Southeast-flowline boundary & 0 & 0 & 194 & 8 \\
\hline Total & 2,239 & 100 & 2,550 & 100 \\
\hline Percentage difference, 1980 and RASA inflow & 14 & & & \\
\hline
\end{tabular}

\section{Outflow}

\begin{tabular}{lrrr}
\hline Water-table boundary & & & 124 \\
$\quad$ Ground-water withdrawals $\quad 37$ & 2 & 5 \\
$\quad$ Irrigation & 8 & 1 & 2,427 \\
$\quad$ Industrial & 2,037 & 98 & 2,551 \\
Southwest boundary & 2,082 & 100 & 1 \\
\hline Total & 157 & 7 & 0 \\
Budget residual & & & 100 \\
Percentage difference between inflow and outflow & 23 & & \\
Percentage difference, 1980 and RASA outflow & &
\end{tabular}

part of the model area, various estimates of these factors were used to compute underflow estimates. Underflow estimates ranged from 1,731 to $2,343 \mathrm{ft}^{3} / \mathrm{s}$; the average of this range, $2,037 \mathrm{ft}^{3} / \mathrm{s}$, was used for the conceptual model. This range represents a difference of $612 \mathrm{ft}^{3} / \mathrm{s}$, or about 25 percent of the $2,427 \mathrm{ft}^{3} / \mathrm{s}$ RASA-derived estimate for underflow across the southwest boundary. The distribution of flow along the 22-mi length of the southwest boundary of the conceptual model, for each vertical stack of cell faces in the three-layer RASA model, ranges from a minimum of $1.2 \mathrm{ft}^{3} / \mathrm{s}$ at the north corner of this boundary to a maximum of $606 \mathrm{ft}^{3} / \mathrm{s}$ at the south corner, and averaged $404 \mathrm{ft}^{3} / \mathrm{s}$. Because the alignment of the southwest boundary of the conceptual model is coincident with a grid line in the RASA model (fig. 16), interpolation errors were limited to the south corner of the boundary, where interpolation of the $606 \mathrm{ft}^{3} / \mathrm{s}$ outflow across the vertical stack of cell faces at this corner of the boundary can introduce a substantial difference in outflow estimates.

Noncompensating summation errors were the likely source of budget differences for the southeast-flowline boundary, which was treated as a noflow boundary in the conceptual model. Inflows across the southeast- 
flowline boundary of the conceptual model were based on the summation of interpolated flows into and out of a stair-stepped array of 19 three-layer stacks of cells consisting of 63 cell faces in the RASA model (Garabedian, 1992) that approximate the southeast boundary of the conceptual model (fig. 16). Along this boundary, 10 three-layer vertical cell stacks produce a net outflow and 11 produce a net inflow. Flow into or out of a single three-layer vertical stack of cell faces along this boundary ranges from a minimum of $9 \mathrm{ft}^{3} / \mathrm{s}$ to a maximum of $594 \mathrm{ft}^{3} / \mathrm{s}$ and averages $125 \mathrm{ft}^{3} / \mathrm{s}$. Summation of inflows and outflows across this boundary were susceptible to both interpolation errors and summation errors that probably are not fully compensating, and these kinds of errors could have resulted in the $194 \mathrm{ft}^{3} / \mathrm{s}$ difference between the conceptual-model inflow estimates and the RASA-derived inflow estimates (table 6).

Precipitation-recharge estimates for the RASA-derived budget were $87 \mathrm{ft}^{3} / \mathrm{s}$ larger than those for the conceptual model budget, but most of this difference represents a 59-percent allocation $\left(92 \mathrm{ft}^{3} / \mathrm{s}\right)$ of the total precipitation recharge $\left(157 \mathrm{ft}^{3} / \mathrm{s}\right)$ in the RASA-derived budget to the southwest corner of the conceptual model, an area that represents 18 percent $\left(352 \mathrm{mi}^{2}\right)$ of the conceptual model area (fig. 16). In the RASA model, this allocation represents a precipitation-recharge flux of $0.26\left(\mathrm{ft}^{3} / \mathrm{s}\right) / \mathrm{mi}^{2}$. This flux is more than six times larger than estimates for the remainder of the conceptual model area, 0.04 $\left(\mathrm{ft}^{3} / \mathrm{s}\right) / \mathrm{mi}^{2}$. The larger precipitation-recharge estimate for this area in the RASA model was attributed to the presence of bare basalt outcrops and the assumed effects of higher altitude on precipitation. However, there are few data to justify this large estimate.

Other noteworthy differences in the two groundwater budgets are attributed to differences in accounting methodology. These include (1) an irrigation infiltration component of $24 \mathrm{ft}^{3} / \mathrm{s}$ in the conceptual model budget that was accounted for in the surface-water irrigation component of the RASA-derived budget, (2) flow across the base of the aquifer that was assumed to be zero in the RASA-derived budget but was estimated to be as large as $44 \mathrm{ft}^{3} / \mathrm{s}$ in the conceptual model budget, and (3) northwest mountain-front boundary underflow of $48 \mathrm{ft}^{3} / \mathrm{s}$ in the RASA-derived budget that was not accounted for separately in the conceptual model budget.

Inflows from the northwest mountain-front boundary, the northeast boundary, and streamflow infiltration are similar in the two budgets. Combined inflows of 2,054 $\mathrm{ft}^{3} / \mathrm{s}$ for these components in the RASA-derived budget compare favorably with combined inflows of 2,015 $\mathrm{ft}^{3} / \mathrm{s}$ for these components in the conceptual model budget.

Differences in the two water budgets emphasize the probable magnitude of the uncertainty associated with current water-budget estimates. This uncertainty is approximately \pm 7 percent of the average value of the total inflow $(2,395$ $\left.\mathrm{ft}^{3} / \mathrm{s}\right)$ and \pm 10 percent of the average value of the total outflow $\left(2,317 \mathrm{ft}^{3} / \mathrm{s}\right)$ of the two budgets. These averages do not include any adjustments for the residual flow shown in table 6 .

\section{Ground-Water Movement}

Water-table maps, based primarily on water levels from the upper $200 \mathrm{ft}$ of the of the eastern SRP aquifer, indicate that the direction of regional ground-water flow is from northeast to southwest (fig. 3) (Garabedian, 1992, fig. 26). Water-table maps for the central part of the INL, however, indicate ground water in this area flows southward and southeastward. Locally, flow directions in the INL vary from southeast to southwest in response to episodic recharge from streamflow-infiltration. Flow increases progressively in a direction downgradient of the northeast boundary because of mountain-front and tributary-valley underflows along the northwest boundary and precipitation recharge and streamflow-infiltration recharge across the water-table boundary. Ground-water flows through all three hydrogeologic units beneath the INL. In the northern part of the INL and south of the INL, the younger rocks (hydrogeologic units 1 and 2) are either absent or are above the water table and all flow takes place through the slightly altered basalts composing the intermediate-age rocks (hydrogeologic unit 3).

Horizontal hydraulic gradients and the direction and velocity of horizontal ground-water movement have been inferred from water-table maps and interpretations of waterchemistry data and are primarily representative of the upper $200 \mathrm{ft}$ of the aquifer in the model area. The earliest water-table maps for the eastern SRP aquifer were compiled during 1928-30 (Stearns and others, 1938) and, over the past 50 years, tens of thousands of aquifer water-level measurements were collected by the USGS. In 2004, for example, about 670 water levels were measured at 172 aquifer wells and 36 perched-water wells in the model area. Water-chemistry data were routinely collected by the USGS in the model area since 1950. In 2004, for example, water samples were collected at 133 aquifer wells, 26 perchedwater wells, and 7 surface-water sites. Water-chemistry data referred to in this report include (1) major and trace elements, (2) stable isotope ratios, (3) isotopes resulting from water-rock interactions, (4) atmospheric tracers, and (5) concentrations or ratios of contaminants discharged at facilities.

Water moves horizontally in the aquifer principally through porous interflow zones between basalt flows rather than in the massive interiors of basalt flows (Whitehead, 1992, p. 26). Because interflow zones are more prevalent in the densely fractured basalt of hydrogeologic unit 1 than in the 
massive, less densely fractured basalt of hydrogeologic unit 2, the amount of water moving through hydrogeologic unit 1 is probably much larger than that moving through hydrogeologic unit 2.

Ground water moves vertically in the aquifer principally through fracture systems (Mann, 1986, p. 21). Water also moves vertically through fine-grained sediment and massive basalts, but vertical movement probably is impeded substantially by these relatively horizontal, impermeable layers. Few data were available to define the vertical hydraulic gradients and the vertical movement of ground water in the aquifer. The data that were available were (1) measurements of hydraulic head at several depths during drilling and testing of the 10,365-ft deep INEL 1 test hole (fig. 1), (2) water-level measurements from dedicated piezometers located at various depths in wells USGS 30 and Hwy 1 (fig. 1), and (3) intraborehole flow measurements of upward or downward groundwater flow in 16 wells located near TAN, the Naval Reactors Facility (NRF), the TRA, and the INTEC (fig. 1).

\section{Horizontal Hydraulic Gradient}

Horizontal hydraulic gradients vary spatially across the model area in response to local changes in hydraulic conductivity, aquifer thickness, and recharge. These watertable gradients were defined by measurements of water levels in 201 aquifer wells in the model area, of which 175 wells are in the INL. A few wells have multiple completions, and of the 207 well completions 158 penetrate only the upper $200 \mathrm{ft}$ of the aquifer. At a regional scale, water-table gradients have remained relatively stable during the past 70 years (see watertable maps in Stearns and others, 1938; Garabedian, 1992, plate 4; and Bartholomay and others, 2000, fig. 9). Locally, however, the gradients may fluctuate annually in response to streamflow-inflitration and irrigation recharge and cyclically over 3- to 8-year periods in response to climate variation and its effect on the quantity of streamflow-infiltration recharge.

Water-table gradients range from about 1 to $60 \mathrm{ft} / \mathrm{mi}$ (fig. 17) in the model area and from about 1 to $8 \mathrm{ft} / \mathrm{mi}$ beneath the INL (fig. 12), and precise definition of flow direction beneath the INL is difficult owing to the small gradient. Gradients near the northeast boundary of the model area range from 27 to $60 \mathrm{ft} / \mathrm{mi}$ (fig. 16) (Lindholm and others, 1988). These large gradients probably are caused by a decrease in hydraulic conductivity associated with fine-grained sediments (Nace and others, 1959, p. 151; Mundorff and others, 1964, p. 133; Lindholm and others, 1988). The gradient in the northern part of the INL is poorly defined, but was estimated to be about $1 \mathrm{ft} / \mathrm{mi}$ near TAN (figs. 1 and 12) (Anderson and Liszewski, 1997, p. 20; Sorenson and others, 2000, p. 340).
In much of the central part of the INL the gradient is about 6 to $8 \mathrm{ft} / \mathrm{mi}$, and this larger gradient probably reflects the larger amount of sediment and the resulting smaller hydraulic conductivity in this area (fig. 12) (Anderson and Liszewski, 1997 , p. 20-21). Water-level contours (fig. 12) indicate a gradient of about 2 to $4 \mathrm{ft} / \mathrm{mi}$ in most of the southern and eastern parts of the INL, except in the area north and east of Middle and East Buttes, where gradients are about 4 to $6 \mathrm{ft} / \mathrm{mi}$. The smaller gradient in the southern and eastern parts of the INL may reflect increased transmissivity resulting from less sediment and greater aquifer thickness in this area (figs. 12 and 14), and the larger gradient north and east of Middle and East Buttes probably results from the smaller hydraulic conductivity associated with the silicic rocks in this area. Gradients southwest of the INL range from about 4 to $30 \mathrm{ft} / \mathrm{mi}$ (fig. 17) (Lindholm and others, 1988). The larger gradients may result from structural uplift in this area, perhaps related to differential subsidence or faulting, or the emplacement of laccoliths and domes within the stratigraphic section (Anderson and others, 1997, p. 5 and fig. 3), causing the relatively impermeable basalts of hydrogeologic unit 2 to intersect the water table (figs. 9 and 10). Alternatively, Lindholm and others (1988) noted that this large gradient is immediately upgradient of, and generally parallel to, a zone of smaller transmissivity. This zone of smaller transmissivity may be attributed to the healing of fractures or the presence of numerous, closely spaced dikes that may be related to the nearby and downgradient Great Rift volcanic rift zone (Lindholm and others, 1988; Anderson and others, 1999, p. 26). In either case, larger gradients would be necessary to move water through the low-permeability basalts of hydrogeologic unit 2 or the low-permeability rocks associated with the rift zone.

\section{Flow Directions in the Central Part of the Idaho National Laboratory}

Although ground water moves southwestward regionally, ground water in the central part of the INL was inferred to flow southward and southeastward on the basis of water-table contours (fig. 12), hydraulic-gradient analyses from waterlevel triangulations (Michael Rohe, Bechtel, Babcock, and Wilcox, Idaho, written commun., 2000), and interpretation of water-chemistry data (Sorenson and others, 1996, figs. 2-23; Johnson and others, 2000, p. 873; Luo and others, 2000, fig. 9b; Busenberg and others, 2001, fig. 25). The southward and southeastward flow directions may result from the flow directions of tributary valley and regional underflow and directional changes in aquifer transmissivity. 
The variation in flow direction may be attributable to the two principal sources of water to the aquifer beneath the INL: (1) regional underflow from the northeast (55 percent of total estimated inflow for 1980; table 6) and (2) tributary-valley underflow (Big Lost River, Little Lost River, and Birch Creek valleys) from the northwest (31 percent of total estimated inflow for 1980; table 6). Underflow from the Little Lost River and Birch Creek valleys (15 percent of total estimated inflow for 1980; table 6) enters the eastern SRP aquifer in the north-central and northern parts of the INL (fig. 17), respectively. These valleys trend southeastward and, given the large hydraulic gradients at the mouths of these valleys, underflow entering the eastern SRP aquifer from these valleys would be expected to flow in the same direction. When the tributary valley underflow converges with regional underflow, which moves in a southwesterly direction, the combined gradients driving these flows may produce flow that moves in a southerly direction.

Evidence that tributary-valley and regional underflow converge in the central part of the INL is provided by the chemical signatures of ground water in this area. Regionalsource and tributary-valley source ground water are distinguishable beneath the INL because these ground waters originate in silicic and carbonate aquifers, respectively, and contain distinctive chemical signatures (Olmstead, 1962, p. 37-38; Robertson and others, 1974, p. 42-55). Concentrations of major ions (potassium, sodium, calcium, magnesium, fluoride, bicarbonate), silica, trace elements (lithium, boron, strontium), and stable isotope ratios (delta oxygen-18, delta carbon-13) in waters from the eastern SRP aquifer (Olmstead, 1962, p. 37-38; Robertson and others, 1974, p. 42-55; Busenberg and others, 2001, figs. 3-5 and 35-36), indicate that ground water beneath the southeastern part of the INL retains the chemical signature of regional ground water and ground water beneath the northwestern part of the INL retains the chemical signature of ground water from the tributary valleys. For example, lithium (Li) concentrations beneath the southeastern part of the INL are greater than $5 \mu \mathrm{g} / \mathrm{L}$, similar to those in regional ground water, and beneath the northwestern part of the INL they are less than $5 \mu \mathrm{g} / \mathrm{L}$, similar to those in tributary-valley ground water (fig. 19). The lithium line in figure 19 separates the area of Li concentrations in the aquifer attributed to regional ground water (greater than $5 \mu \mathrm{g} / \mathrm{L}$ ) from that attributed to tributary-valley ground water (less than $5 \mu \mathrm{g} / \mathrm{L}$ ), and the line may indicate the area where regional and tributary-valley ground water converge.

Ground water also was interpreted to flow southward through the central and northern parts of the INL by identifying water-rock interactions that produced chemically-evolved isotope concentrations (uranium and thorium decay-series disequilibria: uranium, thorium, and radium isotopes) (Luo and others, 2000, fig. 9b) and distinctive stable isotope ratios (strontium-87/strontium-86) (Johnson and others, 2000, fig. 2a). Fast-flow zones were interpreted to extend south from the mouths of the Little Lost River and Birch Creek and slow-flow zones were interpreted to be present in the western and central parts of the INL. These fast- and slow-flow zones, however, may not be consistent with ground-water flow velocities calculated by Busenberg and others $(1993,2001)$, as shown on figure 20, on the basis of model ages of water using atmospheric tracers $\left({ }^{3} \mathrm{H} /{ }^{3} \mathrm{He}\right.$, chlorofluorocarbon) and contaminant ratios $\left({ }^{3} \mathrm{H} /{ }^{\beta} \mathrm{He}\right)$. The model ages indicated slower flow ( 2 to $8 \mathrm{ft} / \mathrm{d}$ ) between the mouth of the Little Lost River and the INTEC and faster flow (10 to $14 \mathrm{ft} / \mathrm{d}$ ) in the central part of the INL (fig. 20) (Busenberg and others, 1993, p. 30; Busenberg and others, 2001, fig. 25). Busenberg and others (2001, p. 54) state that the results of their study are consistent with the interpretation of a fast-flow zone in the central part of the INL by Luo and others (2000, fig. 9b) and Johnson and others (2000, fig. 2a). Although the results of Busenberg and others (2001, fig. 25) support a conclusion that fast- and slow-flow zones exist in the aquifer beneath the INL, the fast-flow zone in the central part of the INL indicated by Busenberg and others (2001, fig. 25) is not located within the fast-flow zones indicated by Luo and others (2000, fig. 9b) and Johnson and others (2000, fig. 2a).

The transition from southerly flow in the central part of the INL to regional, southwesterly flow also may reflect differences in aquifer transmissivity beneath the INL. The aquifer is thinner near the mountain fronts, thickens to the southeast, and is thickest along the southeast model boundary (fig. 14). These aquifer thicknesses and the distribution of hydrogeologic units and hydraulic properties described in the section, "Hydrogeologic Framework and Hydraulic Properties," (figs. 9 and $\underline{12}$, table 2), indicate that the transmissivity of the aquifer probably is (1) smaller in the northern and southwestern parts of the INL, (2) larger in the central and eastern parts of the INL, and (3) much smaller in the northwestern than in the southeastern part of the INL. This smaller-to-larger northwest-to-southeast difference in aquifer transmissivity indicates that there is less regional underflow through the northwestern than through the southeastern part of the aquifer. The lesser volume of regional underflow in the northwestern part of the INL probably allows the volume and direction of tributary-valley underflow to exert a relatively large influence on shallow flow directions in the northern and central part of the INL. 

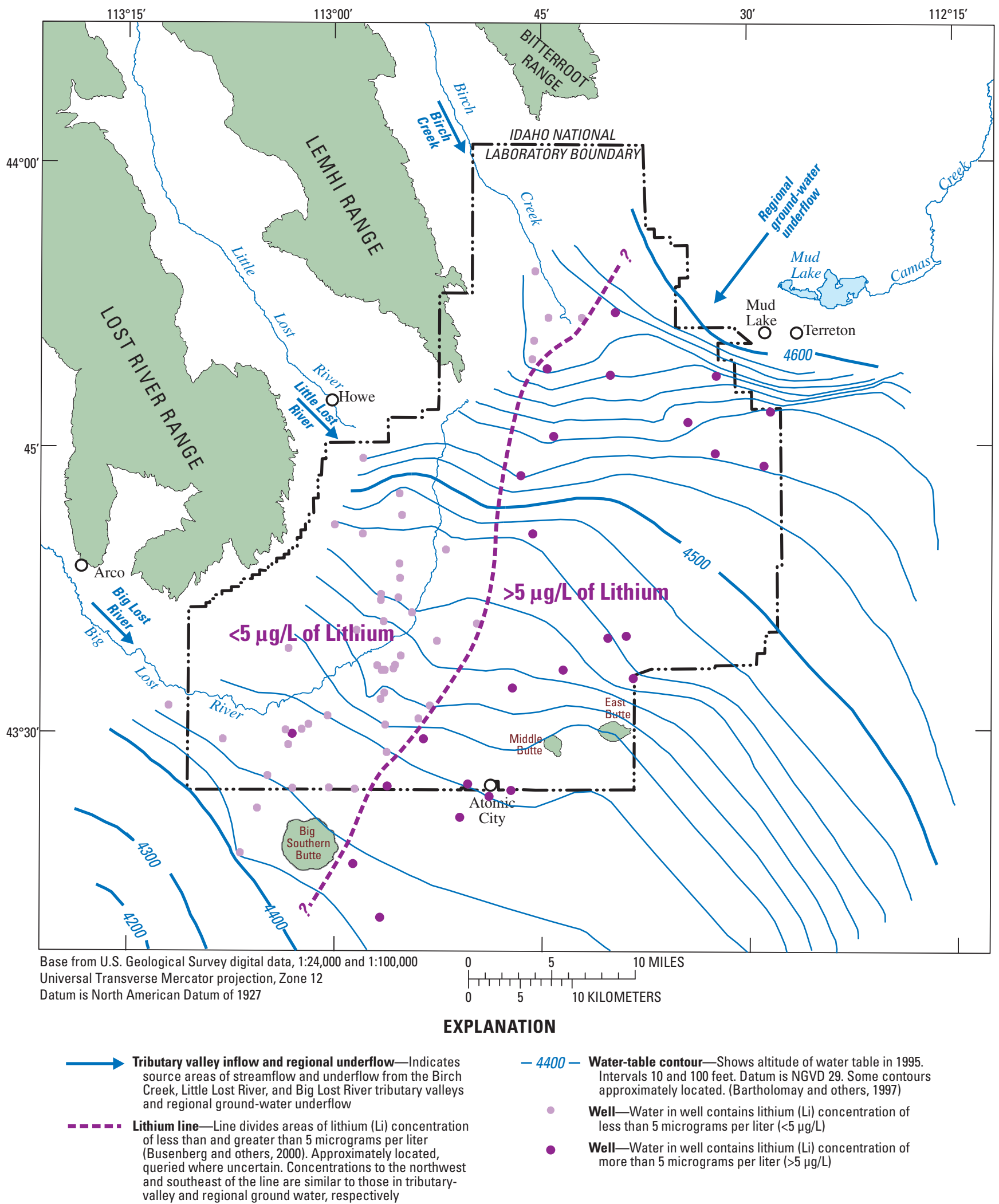

- 4400 - Water-table contour-Shows altitude of water table in 1995. Intervals 10 and 100 feet. Datum is NGVD 29. Some contours approximately located. (Bartholomay and others, 1997)

- Well-Water in well contains lithium (Li) concentration of less than 5 micrograms per liter $(<5 \mu \mathrm{g} / \mathrm{L})$

- Well-Water in well contains lithium (Li) concentration of more than 5 micrograms per liter $(>5 \mu \mathrm{g} / \mathrm{L})$

Figure 19. Distribution of lithium concentrations in water from wells in the eastern Snake River Plain aquifer, Idaho National Laboratory and vicinity, Idaho.

Water samples were collected between 1995 and 1997. 


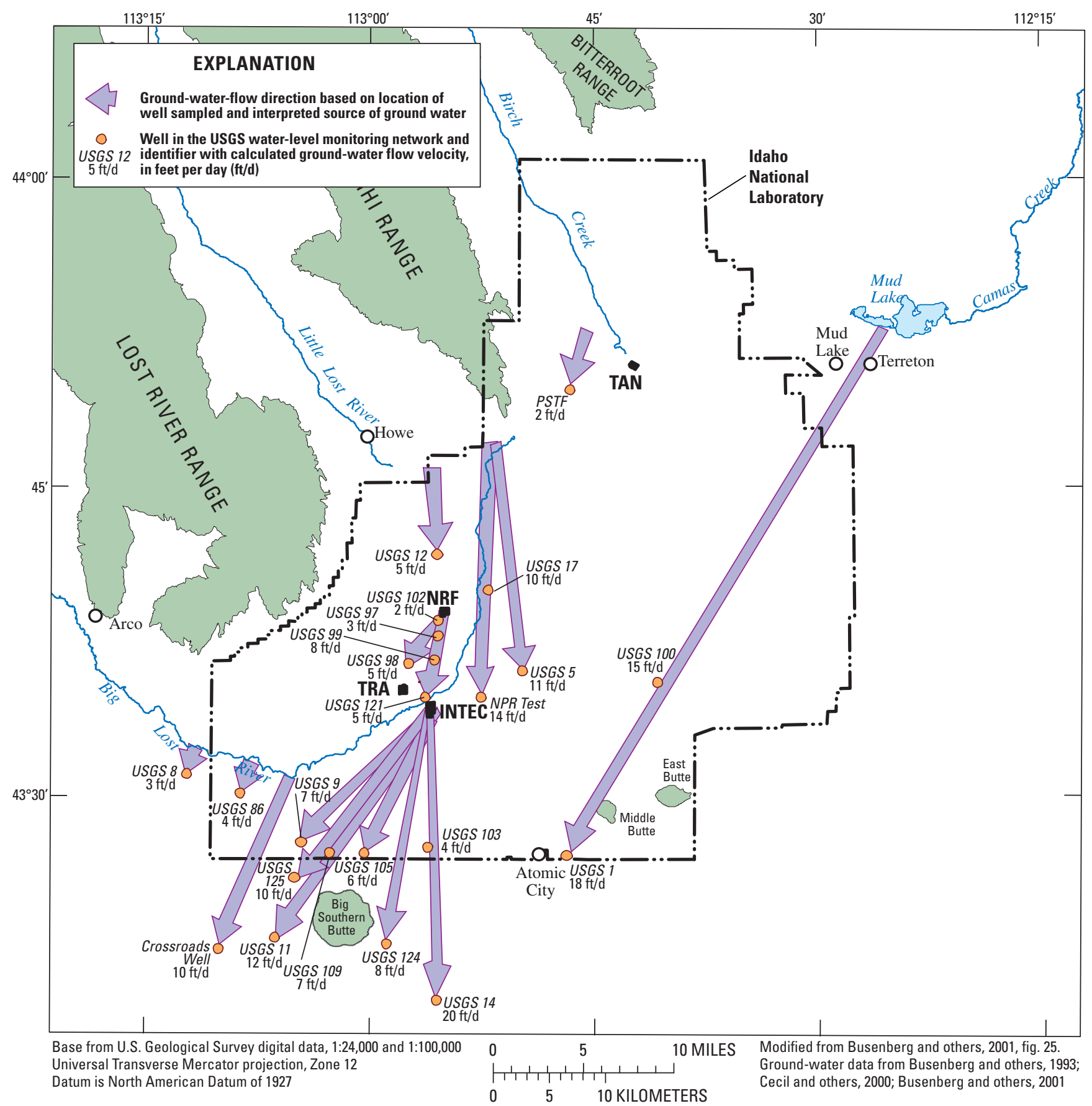

Figure 20. Average linear ground-water velocities and flow directions calculated from the assumed first arrivals of chlorine-36 or the tritium/helium-3- and chlorofluorocarbon-model ages of water from selected wells, Idaho National Laboratory and vicinity, Idaho.

TAN, Test Area North; NRF, Naval Reactors Facility; TRA, Test Reactor Area; INTEC, Idaho Nuclear Technology and Engineering Center. 


\section{Effect of Episodic Recharge from the Big Lost River on Variation of Local Flow Directions}

Flow directions beneath the southwestern part of the INL vary temporally because of gradient reversals produced by episodic streamflow-infiltration recharge from the Big Lost River (Barraclough and others, 1976, p. 52-56). Flow in the Big Lost River is usually largest in the spring and early summer when snow melts in the high-altitude river basin and, during years with sufficient precipitation, runoff reaches the central and southwestern parts of the INL where it infiltrates and recharges the aquifer. During wet years, flow in the Big Lost River in the central part of the INL was more than three times $\left(190 \mathrm{ft}^{3} / \mathrm{s}\right)$ the average annual streamflow $\left(55 \mathrm{ft}^{3} / \mathrm{s}\right)$ and flow diverted to the spreading areas was more than seven times $\left(379 \mathrm{ft}^{3} / \mathrm{s}\right)$ the average annual streamflow $\left(48 \mathrm{ft}^{3} / \mathrm{s}\right)$ (table 5; streamflow-gaging stations 13132520 and 13132513 , respectively). This large amount of cold surface-water recharge probably acts as a persistent heat sink in the aquifer and could have depressed ground-water temperatures in these areas (fig. 21).

Pulses of streamflow-infiltration recharge have created large localized water-level changes and water-table mounds (fig. 22) in the low-gradient area beneath the central INL (fig. 17). For example, in the early 1980s larger than normal streamflow infiltrated and recharged the aquifer during a wet climate cycle. The water table rose unevenly beneath the INL, and water-table mounds formed near the Big Lost River spreading areas and in the area north of the NRF. The water table fell unevenly during a dry cycle in the late 1980s and early 1990s, when there was no streamflow recharge, and the water-table mounds dissipated. Water-table mounds were less pronounced during a wet cycle in the late 1990s when the water table rose moderately.

Nonuniform water-level changes are typical beneath the INL, with the largest changes occurring near or beneath areas of episodic recharge. Hydrographs of water levels in well USGS 9 near the spreading areas and well USGS 12 north of the NRF show water-level rises from 13 to $16 \mathrm{ft}$ during and following the wet climate cycle in the early 1980s, and declines from 16 to $22 \mathrm{ft}$ during the dry climate cycle of the late 1980s and early 1990s (fig. 23). The water level at well USGS 9 reached its highest peak of the period 1948-2003 in 1984 (fig. 23), the second year of a 2-year period of recordhigh diversions to the spreading areas (fig. 18, gaging station 13132513). The water level in well USGS 9 dropped rapidly after diversions to the spreading areas decreased during
1985. In contrast, the high water levels in well USGS 12 that persisted from 1985 through 1987 (fig. 23) reflect the more uniform flow in the Big Lost River downstream of the INL diversion dam (fig. 18, gaging station 13132520) between 1982 and 1986. During the wet climate cycle of the early 1980s, the rise in water levels at wells USGS 25 and Arbor Test, in the northern and southeastern parts of the INL (fig. 1), was about 7 and $11 \mathrm{ft}$, respectively (fig. 23). The smaller increase in water levels at these wells in response to the wet climate cycle probably reflects their greater distance from the localized pulses of streamflow-infiltration recharge. A similar but smaller rise in water levels at these four wells was recorded during the wet climate cycle of the late 1990s (fig. 23).

Ground water in and near a water-table mound would be expected to flow radially away from the mound and, at the INL, water east of the mound would be expected to flow southward and southeastward around the mound. An example of how local flow directions may vary, and may even reverse direction owing to water-table mounds was presented by Barraclough and others (1976, p. 52-56 and fig. 33). On the basis of water-level measurements in the vicinity of the RWMC during 1972, Barraclough and others (1976, p. 52-56 and fig. 33) inferred that ground water flowed away from and around a water-table mound near the Big Lost River spreading areas (fig. 1). They noted that the northeast direction of flow indicated by these data was counter to the prevailing southwestern regional flow direction, and suggested that streamflow-infiltration recharge from the Big Lost River spreading areas appeared to be the predominant influence on this anomalous flow direction.

The variation in the direction of ground-water flow in response to pulses of streamflow-infiltration recharge may be large, perhaps tens of degrees. Simulated flow directions in a flow-and-transport model (Goode and Konikow, 1990b, p. 420 , fig. 2) varied by as much as 20 degrees, between N. $70^{\circ}$ E. to N. $90^{\circ}$ E., about $700 \mathrm{ft}$ downgradient of the disposal well (CPP 3) at the INTEC in response to variable streamflow-infiltration recharge from the Big Lost River. Larger, unreported, variations in flow directions may have been present at other locations in the model. Flow directions west of INTEC, near the Big Lost River, were interpreted to range from about N. $80^{\circ}$ E. to N. $280^{\circ}$ W. during 1976-1998 based on a study evaluating the temporal fluctuation of hydraulic gradients at the INL (Michael Rohe, Bechtel, Babcock, and Wilcox, Idaho, written commun., 2000). 


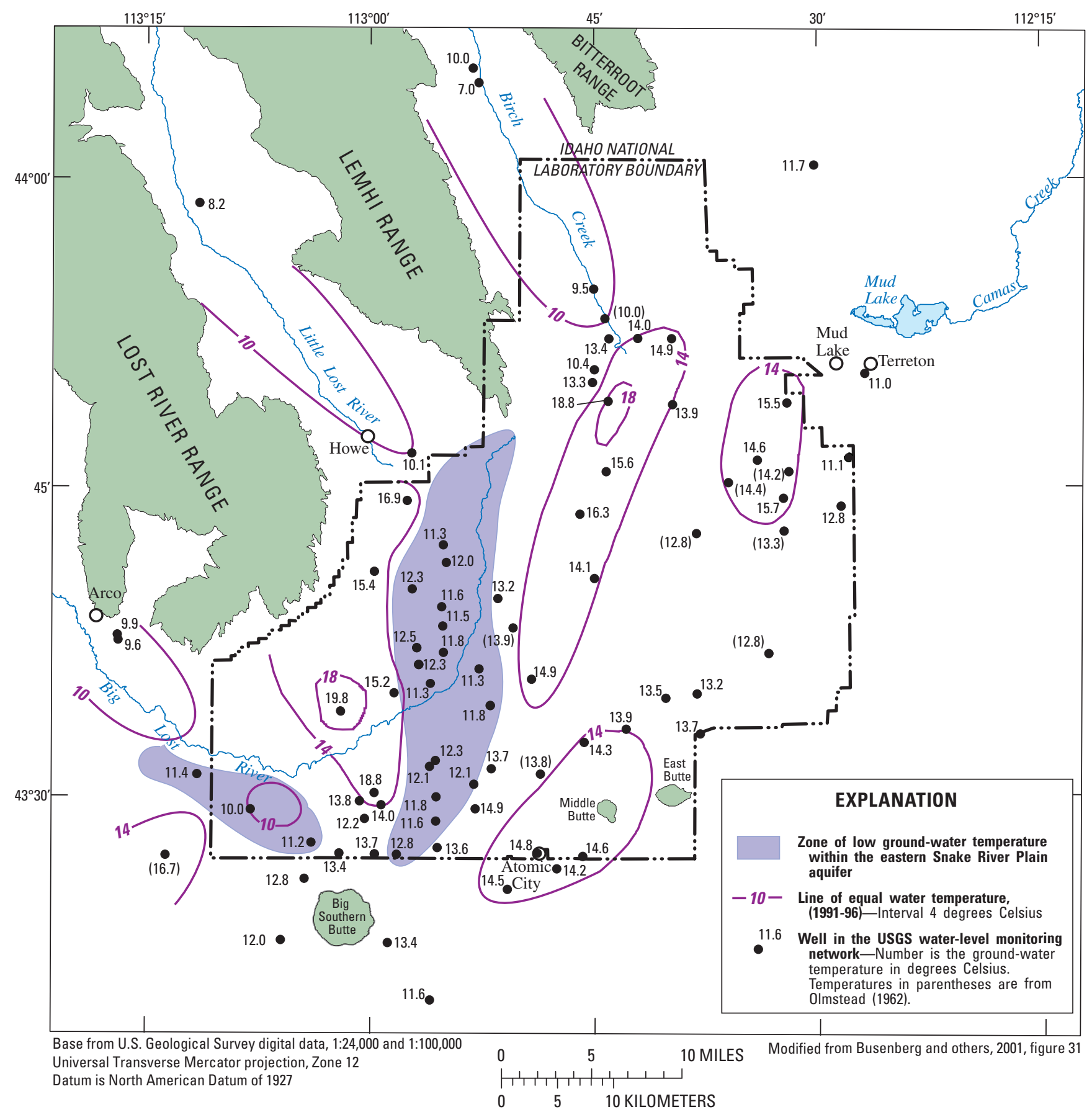

Figure 21. Temperature of ground water in samples from wells, Idaho National Laboratory and vicinity, Idaho. 


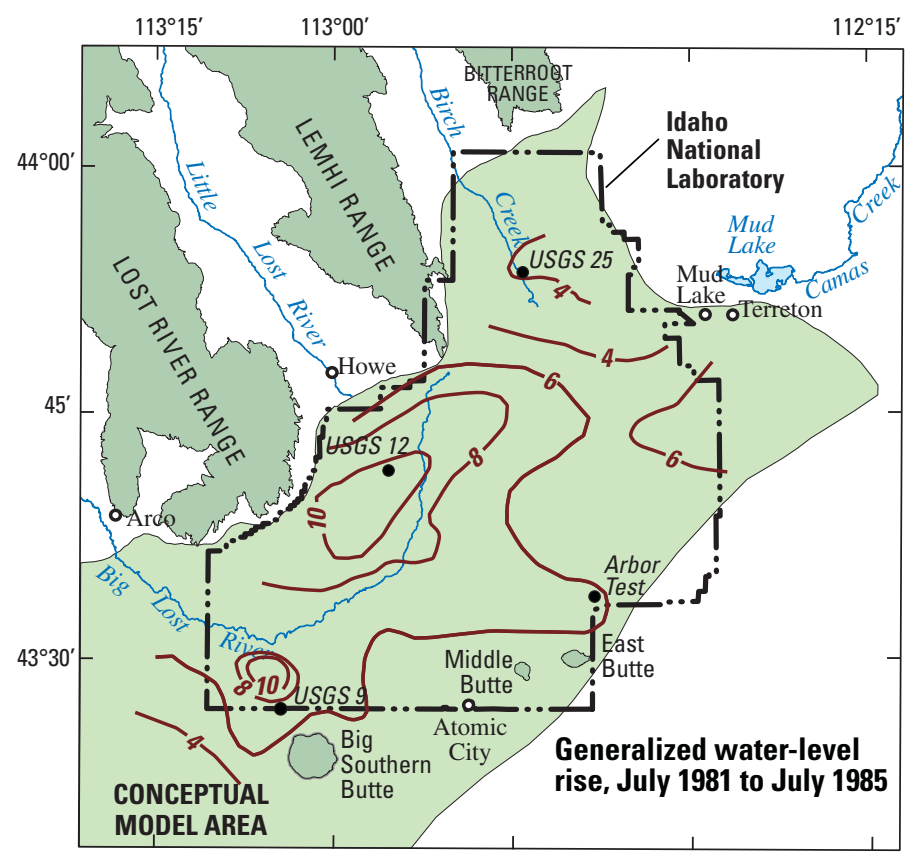

Modified from Pittman and others, 1988, fig. 10.

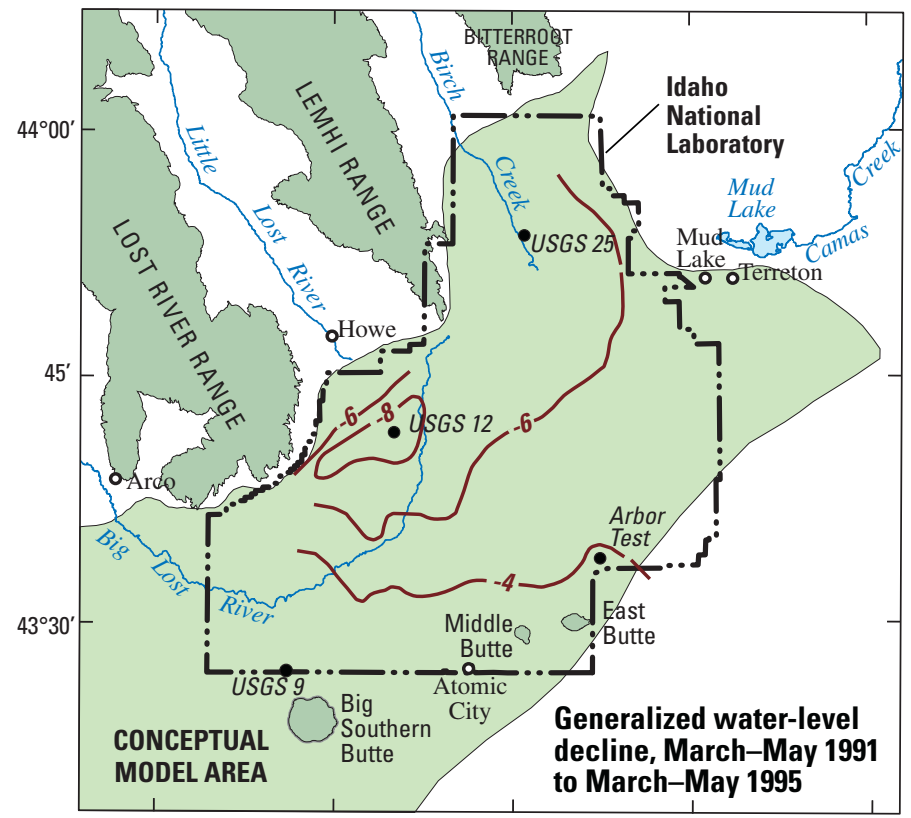

Base from U.S. Geological Survey digital data, 1:24,000 and 1:100,000

Universal Transverse Mercator projection, Zone 12

Datum is North American Datum of 1927

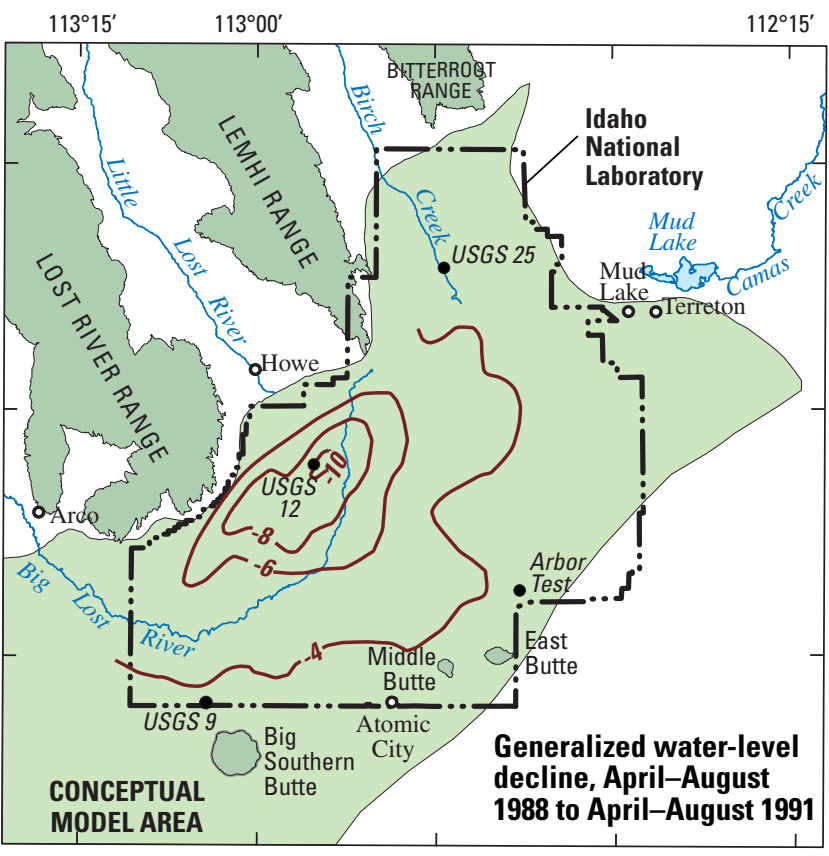

Modified from Bartholomay and others, 1995, fig. 10.

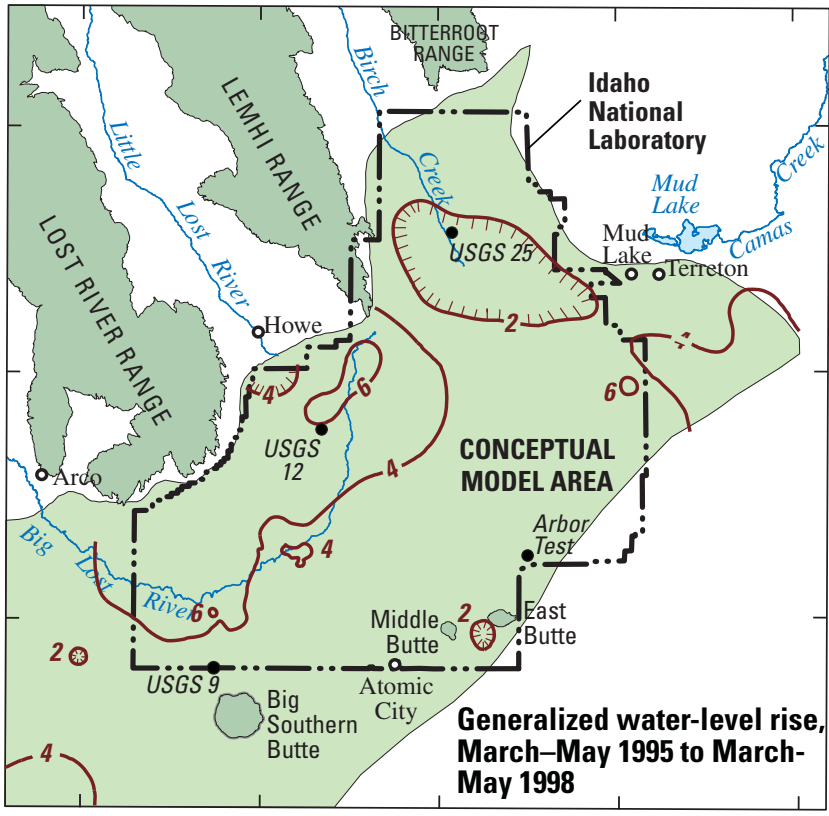

$\stackrel{0}{5} 10$ MILES

$\begin{array}{lll}0 & 5 & 10 \\ & \text { KILOMETERS }\end{array}$

Modified from Bartholomay and others, 2000, fig. 10.

\section{EXPLANATION}

$$
\begin{aligned}
& \text {-27T Line of equal water-level change-Interval } 2 \text { feet. Negative value } \\
& \text { indicates water-level decline. Hachures indicate water-level } \\
& \text { change is less than the contour value }
\end{aligned}
$$

Figure 22. Generalized water-level changes at the Idaho National Laboratory and vicinity, Idaho, for July 1981-July 1985, April-August 1988 to April-August 1991, March-May 1991 to March-May 1995, and March-May 1995 to MarchMay 1998. 


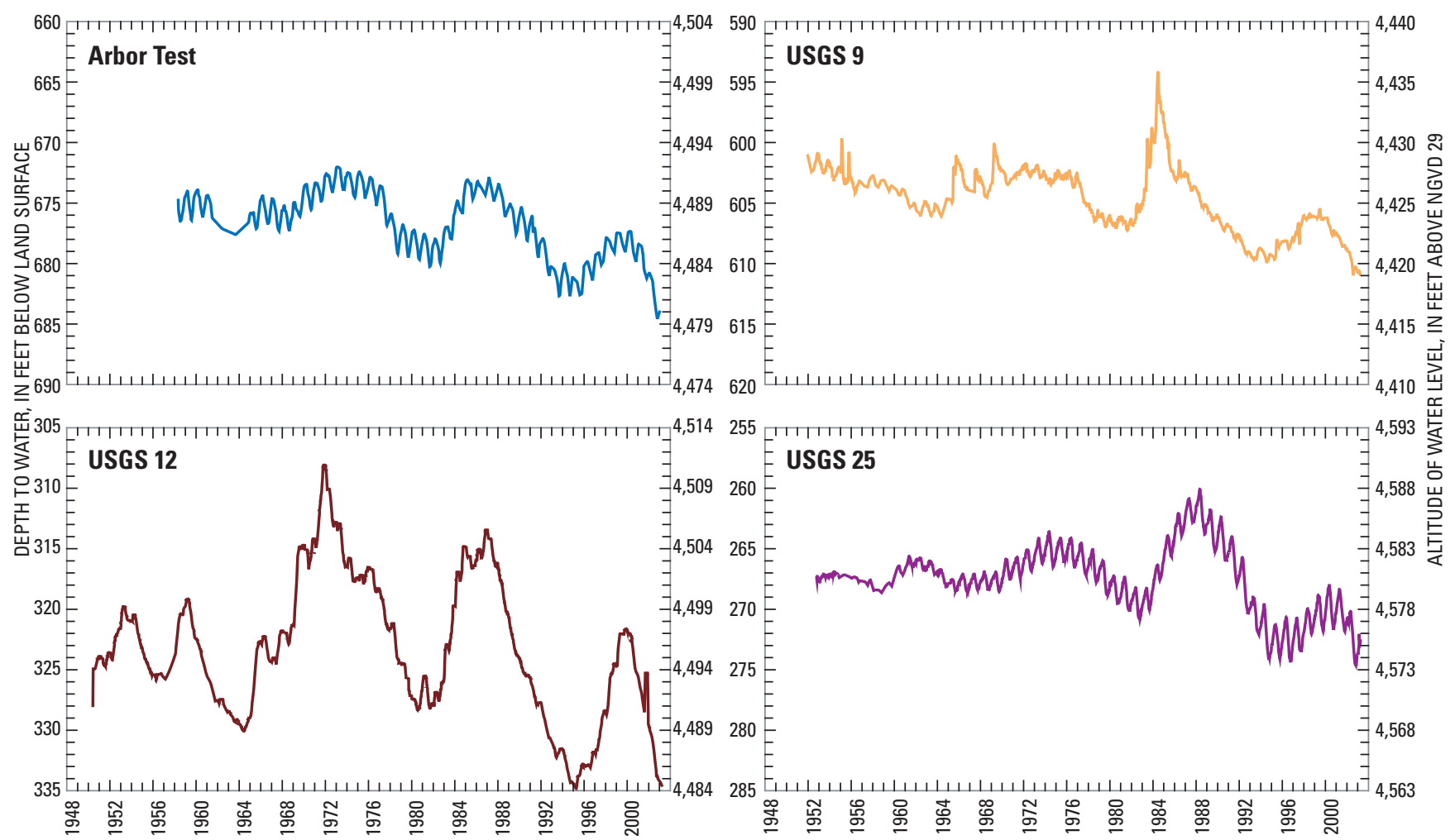

Figure 23. Water levels in wells Arbor Test, USGS 9, USGS 12, and USGS 25 for 1948-2003, Idaho National Laboratory, Idaho. Water-level data are from the web site http://waterdata.usgs.gov/id/nwis/gwlevels. NGVD 29, National Geodetic Vertical Datum of 1929. Location of wells shown in figure 1.

\section{Average Linear Ground-Water Velocities}

The estimated average linear ground-water velocities in the model area range from 2 to $20 \mathrm{ft} / \mathrm{d}$ (fig. 20) and were determined from concentrations or ratios of atmospheric tracers $\left({ }^{3} \mathrm{H} /{ }^{3} \mathrm{He}\right.$, chlorofluorocarbons) and long-term monitoring of contaminant movement in the aquifer $\left({ }^{3} \mathrm{H},{ }^{129} \mathrm{I}\right.$, $\left.{ }^{36} \mathrm{Cl},{ }^{3} \mathrm{H} /{ }^{3} \mathrm{He}\right)$. Velocities determined using atmospheric tracers were estimated from the ${ }^{3} \mathrm{H} /{ }^{3} \mathrm{He}$ - or chlorofluorocarbonmodel age of the water and the probable location of recharge (Busenberg and others, 1993, p. 29; Busenberg and others, 2001, p. 41, fig. 25). Velocities determined using concentrations or ratios of contaminants discharged at facilities were calculated based on assumed first-arrival times of contaminants at wells downgradient of known contaminant input locations (Barraclough and others, 1981, p. 59; Pittman and others, 1988, p. 51; Mann and Beasley, 1994, p. 24; Cecil and others, 2000, p. 686). Velocities were estimated to be $2 \mathrm{ft} / \mathrm{d}$ near TAN (Busenberg and others, 1993, p. 30; Busenberg and others, 2001, fig. 25); 15 to $18 \mathrm{ft} / \mathrm{d}$ between Mud Lake and Atomic City (Busenberg and others, 1993, p. 30); 2 to $14 \mathrm{ft} / \mathrm{d}$ in the area north and east of the TRA and southeast of Howe (Busenberg and others, 1993, p. 30; Busenberg and others, 2001, fig. 25); 4 to $20 \mathrm{ft} / \mathrm{d}$ south of the TRA and INTEC (Barraclough and others, 1981, p. 59; Pittman and others, 1988, p. 51; Mann and Beasley, 1994, p. 24; Cecil and others, 2000, p. 686; Busenberg and others, 2001, fig. 25); and 3 to $4 \mathrm{ft} / \mathrm{d}$ south of the Big Lost River and near the western boundary of the INL (Busenberg and others, 1993, p. 30; Busenberg and others, 2001, fig. 25) (fig. 20).

These estimated average linear ground-water velocities generally correlate with the ranges and spatial distributions of hydraulic conductivity values estimated previously in the section, "Hydrogeologic Units" (table 2). High groundwater velocities were estimated for areas where the highly conductive, densely fractured basalt (hydrogeologic unit 1) is present at the water table, and lower velocities were estimated for areas where less conductive, less densely fractured basalt (hydrogeologic unit 2) and intermediate-age rocks (hydrogeologic unit 3) are present at the water table (fig. 9). Using the range of velocities presented above, an average hydraulic gradient at the INL of $4 \mathrm{ft} / \mathrm{mi}$, a range of effective porosities of 0.1 to 0.2 for fractured basalt and 0.05 to 0.15 for massive basalt and intermediate-age rocks, calculated horizontal hydraulic conductivities range from 300 to $5,000 \mathrm{ft} / \mathrm{d}, 200$ to $800 \mathrm{ft} / \mathrm{d}$, and 100 to $400 \mathrm{ft} / \mathrm{d}$ for the densely fractured basalt (hydrogeologic unit 1), less-densely fractured basalt (hydrogeologic unit 2), and intermediate-age rocks (hydrogeologic unit 3), respectively.

Hydraulic conductivities derived from velocity estimates for the area of ground-water contamination south of the TRA and INTEC range from 500 to $5,000 \mathrm{ft} / \mathrm{d}$ for assumed 
effective porosities of 0.1 and 0.2 . These estimates are generally consistent with results of aquifer testes conducted in hydrogeologic unit 1 . The ground-water velocity in hydrogeologic unit 1 in the range from 4 to $20 \mathrm{ft} / \mathrm{d}$ probably reflects preferential flow along the many interflow zones of the thin, densely fractured basalts composing the uppermost hydrogeologic unit.

High wastewater-discharge rates at disposal wells may produce increased average linear ground-water velocities downgradient of the wells. Evidence of an increase in ground-water velocity in the area between the disposal well (CPP 3) at the INTEC and two wells (USGS 40 and USGS 41, in fig. 1) less than 1,000 ft to the southwest was provided in two tracer studies conducted one year apart (Jones, 1963). During the first tracer study, the rate of wastewater discharged at CPP 3 was gradually increased from less than $100 \mathrm{gal} / \mathrm{min}$ to about $700 \mathrm{gal} / \mathrm{min}$. During the second tracer study, the discharge rate remained steady at about $970 \mathrm{gal} / \mathrm{min}$ (Jones, 1963, p. 228). The ground-water velocity between the two wells calculated in the second study was 2 to 4 times higher than that calculated in the first study (Jones, 1963, p. 228). The most probable explanation for this increase in velocity was the higher wastewater-discharge rate at the disposal well during the second study.

\section{Vertical Ground-Water Movement}

The small number of deep wells and the few measurements of vertical hydraulic head and upward or downward ground-water movement provided limited information about the vertical gradients and movement of ground water in the model area, but did demonstrate that the direction of vertical movement is spatially variable. The information available regarding vertical hydraulic conductivity and head indicates that hydraulic conductivity decreases (Mann, 1986, p. 6-14) and hydraulic head increases (Jones, 1961, p. 41; Morin and others, 1993, p. 16-19; Mann, 1986 , p. 14) with depth in the southwestern part of the INL. However, in the upper part of the aquifer, near TAN, the NRF, the TRA, and the INTEC, measurements of ground-water movement in wells indicates that water moves both upward and downward (Morris and others, 1964, p. 40-42; Morris and others, 1965, p. 42-44; Barraclough, Teasdale, and Jensen, 1967, p. 94-98; Morin and others, 1993, table 1).

Water-level measurements ${ }^{2}$ at test hole INEL 1 (fig. 1) show that the hydraulic head at depth (4,210-10,365 ft below land surface) is about $115 \mathrm{ft}$ higher than the head for the upper $200 \mathrm{ft}$ (395-595 ft below land surface) of the aquifer (Mann, 1986, p. 14). Water-level measurements in piezometers at wells USGS 30 and Hwy 1, in the eastern part of the INL and east of the southeast boundary of the model area (fig. 1), respectively, also show head increasing with depth. At well USGS 30, head increases of 2 and $11 \mathrm{ft}$ were measured at

\footnotetext{
${ }^{2}$ Hydrologic data on the World Wide Web may be accessed at http://idaho. usgs.gov/
}

depths of 335 and $545 \mathrm{ft}$ below the water table, respectively, and at well Hwy 1, head increases of 0.4 and $0.3 \mathrm{ft}$ were measured at depths of 100 and $425 \mathrm{ft}$ below the water table, respectively. The increased head with depth at wells USGS 30 and Hwy 1 may be related to the steep hydraulic gradient along the northeast boundary of the model area (fig. 3). The steep gradient coincides with the interfingering of basalt with less transmissive layers of sediment (discussed in the section "Artificial Boundaries"). These sediment layers may act as confining units and, if the deeper sediment layers extend further southwestward than the shallower layers, the heads in the northeastern part of the model area could be larger beneath the deeper sediment layers than in the overlying rocks.

Variation in the direction of vertical ground-water flow in the upper $300 \mathrm{ft}$ of the aquifer is confirmed by measurements of intra-borehole flow at 16 wells. Downward flow was measured at one well ${ }^{3}$ (USGS 4) southeast of TAN, one well (Site 17) north of the NRF, two wells (MTR Test, TRA disposal) at the TRA, and one well (USGS 49) at the INTEC; upward flow was measured at two wells (USGS 28, USGS 31) southeast of TAN and at five wells (USGS 42, USGS 44, USGS 45, USGS 46, USGS 47) at the INTEC; and upward and downward flow was measured at four wells (USGS 48, USGS 51, USGS 52, USGS 59) at the INTEC (Morris and others, 1964, p. 40-42; Morris and others, 1965, p. 42-44; Barraclough, Teasdale, and Jensen, 1967, p. 94-98; Morin and others, 1993, table 1).

\section{Model Representation of Features Affecting Ground-Water Flow}

Ground-water flow through the model area is controlled by the structural and stratigraphic framework of the aquifer and the distribution and timing of hydrologic inputs to and outputs from the model area. Although the conceptual model simplifies geologic and hydrologic features it retains features of the system important for modeling contaminant transport.

\section{Structural and Stratigraphic Controls on Ground- Water Flow}

Structural features in the model area that may control ground-water flow in the aquifer by providing preferential pathways for, and impediments to, flow include (1) rhyolite domes, (2) a sedimentary trough, and (3) volcanic rift zones and vent corridors. Smaller hydraulic conductivities associated with rhyolite domes and rocks in the sedimentary trough decrease flow velocities and may locally alter flow directions where these features are present. Volcanic rift zones and vent corridors may produce both porous, rapid flow zones and vertical, low permeability structures that impede flow.

${ }^{3}$ Wells USGS 4, USGS 28, USGS 31, and Site 17 are shown in figure 1. The other wells discussed in this sentence are located inside or near the indicated facilities and are not shown on map. The facility locations are shown in figure 1. 
The conceptual model represents rhyolite domes, areas of subsidence, uplift, and dipping beds, and the sedimentary trough. It does not represent volcanic rift zones or vent corridors. The effects of volcanic rift zones and vent corridors on ground-water movement in the eastern SRP aquifer are undetermined. Stratigraphic controls on ground-water flow in the model area are the horizontal and subhorizontal layers of basalt and sediment in the eastern SRP aquifer. In the conceptual model, three homogeneous and anisotropic hydrogeologic units (fig. 10) represent the stratigraphic layers. Hydraulic conductivity of each of the three hydrogeologic units reflects the aggregate lithology, thickness, and number of basalt flows and sedimentary interbeds in each hydrogeologic unit. Stratigraphic layers produce both large- and small-scale heterogeneity and horizontal-to-vertical anisotropy in the aquifer.

The large-scale heterogeneity and anisotropy in the aquifer are represented by the subhorizontal layering and differences in hydraulic conductivity among adjacent homogeneous and anisotropic hydrogeologic units (interunit). The difference in conductivity is particularly prominent between hydrogeologic units 1 and 2, with the conductivity of hydrogeologic unit 2 estimated to be much smaller than hydrogeologic unit 1 . Consequently, hydrogeologic unit 2 acts as an impediment to the downward movement of water and contaminants, and wastewater that infiltrates through the unsaturated zone or is discharged to the aquifer at the INL probably is constrained to move in hydrogeologic unit 1 beneath the INL.

Small-scale heterogeneity and anisotropy in the aquifer, which exists in and between the individual basalt flows and sedimentary interbeds (intraunit) that compose the hydrogeologic units, are not represented in the conceptual model. The intraunit stratigraphy produces (1) preferential flow paths and interflow zones that facilitate rapid horizontal ground-water movement, and (2) hydraulic barriers, in the form of massive interiors of individual basalt flows and sedimentary interbeds, that substantially impede vertical ground-water movement. Although the small-scale heterogeneity and anisotropy are not represented in the conceptual model, they could be indirectly represented in the numerical model through the choice of values for the horizontal and vertical hydraulic conductivities for each of the hydrogeologic units.

\section{Hydrologic Controls on Ground-Water Flow}

Hydrologic controls on ground-water flow in the model area include regional and tributary-valley underflow, precipitation and streamflow-infiltration recharge, and industrial wastewater return flows. All these hydrologic controls are represented in the conceptual model. Regional and tributary-valley underflow and precipitation recharge can be adequately modeled by steady-state numerical simulations of flow; however, streamflow-infiltration recharge from the Big Lost River and the variable amounts of industrial wastewater return flows requires transient numerical simulations.

The predominant northeast-to-southwest flow direction through the model area is primarily controlled by regional underflow across the northeast boundary, and the southto-southeast flow direction in the central part of the INL is controlled primarily by underflow entering the eastern SRP aquifer from the Little Lost River and Birch Creek valleys. Regional and tributary-valley underflow entering the model area have undergone gradual changes in magnitude since 1890 in response to climate cycles and changing irrigation practices. However, these changes in underflow do not appear to have affected the magnitude and direction of ground-water flow in the central part of the eastern SRP aquifer. Potentiometric maps of the aquifer indicate that the shape of the water table and flow directions in the model area have remained relatively stable since about 1930 (Garabedian, 1992, p. 21).

In contrast to the gradual changes in underflow entering the model area, large fluctuations were measured in precipitation, streamflow-infiltration recharge, and industrial wastewater return flows. Precipitation and streamflowinfiltration recharge fluctuate annually and in response to short-term (3-8 years), wet-dry climate cycles. Recharge from precipitation in the model area is areally diffuse (about $0.04\left(\mathrm{ft}^{3} / \mathrm{s}\right) / \mathrm{mi}^{2}$ ), and little or no streamflow from the Little Lost River or Birch Creek reaches the INL, so these sources of recharge do not significantly impact water levels or flow directions in the model area. However, because streamflow infiltration from the Big Lost River is spatially focused, fluctuates considerably in response to short-term climate cycles, and can significantly alter water levels and flow directions locally in the model area, it has important consequences for the movement of water and contaminants. Industrial wastewater return flows in the model area have varied in volume and location over time. These flows are small relative to the volume of water flowing through the model area; however, because they occur near contaminated ground water they affect the movement of water and contaminants.

\section{Representation of Ground-Water Flow Through the Model Area}

A semi-quantitative distribution of ground-water flow paths is shown on a vertically-exaggerated hydrogeologic section of the model area (fig. 24). Flow paths drawn on the section were based on flow paths generated with a version of the software package FLOWNET (Fetter, 1994, p. 314). Inflows were based on steady-state conditions. Input for the flow net included (1) a uniform, two-dimensional vertical discretization (cells were $4 \mathrm{mi}$ horizontally and $400 \mathrm{ft}$ vertically) of hydrogeologic units 1,2 , and 3 along the line of section shown in figure 9, (2) inflow across the northeast, northwest mountain-front, and water-table boundaries (fig. 17 


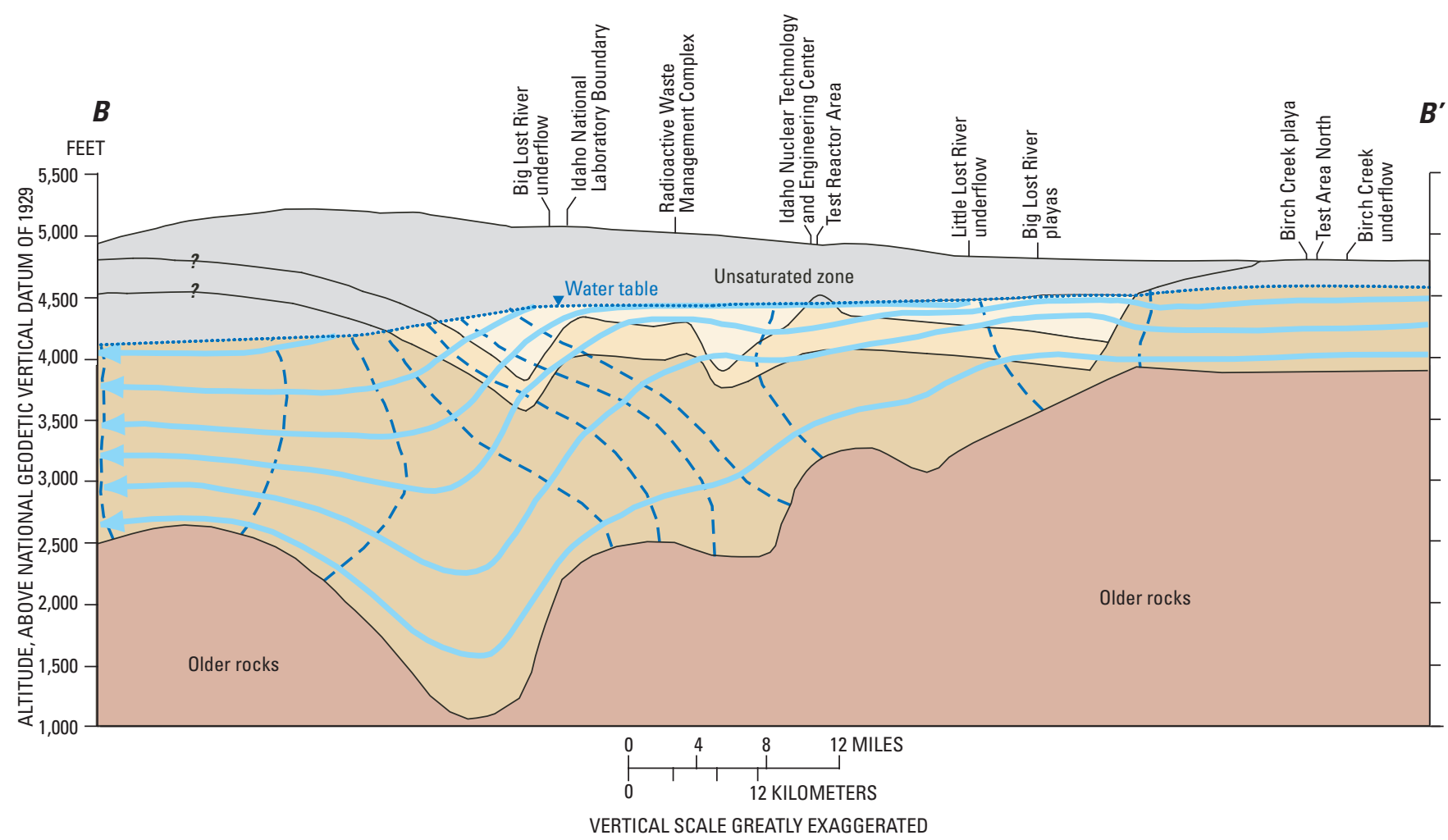

EXPLANATION

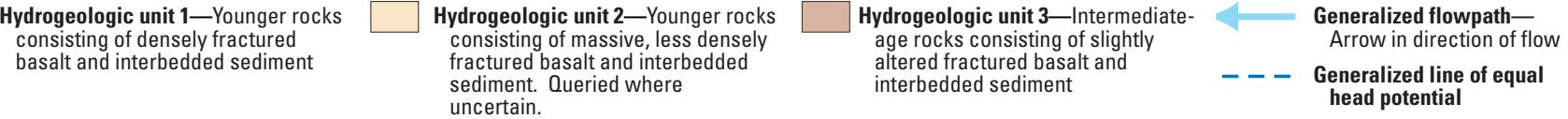

Figure 24. Distribution of hydrogeologic units and the direction of ground-water flow for the model area, Idaho National Laboratory and vicinity, Idaho.

Trace of section is shown in figure 9.

and table $6,(3)$ the altitude of the water table along the line of section shown in figure 9, and (4) estimates of the horizontal hydraulic conductivity $\left(K_{h}\right)$ and vertical hydraulic conductivity $\left(K_{v}\right)$ for hydrogeologic units 1,2 , and 3, where

Hydrogeologic unit 1 (younger rocks - thin, densely fractured basalt)

$$
\begin{aligned}
& K_{h 1}=5,300 \mathrm{ft} / \mathrm{d} \\
& K_{v 1}=400 \mathrm{ft} / \mathrm{d}
\end{aligned}
$$

(estimates from Frederick and Johnson, 1996, p. 59).

Hydrogeologic unit 2 (younger rocks-massive, less-densely fractured basalt)

$$
\begin{aligned}
& K_{h 2}=900 \mathrm{ft} / \mathrm{d} \\
& K_{v 2}=600 \mathrm{ft} / \mathrm{d}
\end{aligned}
$$

(estimates from Frederick and Johnson, 1996, p. 59).

Hydrogeologic unit 3 (intermediate-age rocks-slightly altered fractured basalt)

$$
\begin{aligned}
& K_{h 3}=530 \mathrm{ft} / \mathrm{d} \\
& K_{v 3}=40 \mathrm{ft} / \mathrm{d}
\end{aligned}
$$

Hydrogeologic unit 3 estimates were assumed to be approximately one order of magnitude smaller than those for hydrogeologic unit 1 (John Welhan, Idaho State Geological Survey, written commun., 1999).

Other assumptions that were used to draw flow paths on the hydrogeologic section included:

1. Inflow across the water-table and the northwest mountainfront boundaries as given in table 6, with inflow from the northwest mountain-front boundary represented as inflow across the water table,

2. Uniform, vertical distribution of inflow and outflow across the northeast and southwest boundaries of the model area, respectively,

3. Restriction of ground-water withdrawals to the area near the northeast boundary of the model area,

4. Uniform distribution of precipitation recharge and changes in aquifer storage, and

5. Allocation of streamflow-infiltration recharge from the Big Lost River to the spreading areas (50 percent) and the playas (50 percent). 
Inflows across the water-table boundary were represented on the hydrogeologic section (fig. 24) by superimposing the inflows onto the section. These inflows produced a progressive increase of flow in the aquifer downgradient of the northeast boundary and contributed about 45 percent of the total outflow from the system (table 6).

The hydrogeologic section and semi-quantitative flow paths (fig. 24) indicate that steady-state flow through the aquifer is controlled by the stratigraphic and hydraulic features of the aquifer. The intermediate-age rocks of hydrogeologic unit 3 compose about 75 percent of the aquifer, and most of the water in the aquifer resides in this hydrogeologic unit because of its large volume. Younger rocks of hydrogeologic units 1 and 2 together essentially form a thin layer on top of hydrogeologic unit 3 in the upper and central part of the aquifer. Hydrogeologic unit 1, which is similar in thickness to hydrogeologic unit 2 and much smaller in thickness than hydrogeologic unit 3 , has a much larger hydraulic conductivity than that of hydrogeologic units 2 and 3; consequently, hydrogeologic unit 1 transmits a disproportionately large amount of water. The smaller hydraulic conductivity of hydrogeologic unit 2 and the large horizontal-to-vertical anisotropy of the aquifer $\left(K_{h}\right.$ is much larger than $\left.K_{v}\right)$ generally impedes the downward flow of water from hydrogeologic unit 1 (fig. 24). The pyramid-shaped segment of hydrogeologic unit 2 that extends above the water table in figure 24 is not laterally extensive (fig. 9) and does not significantly impede the horizontal movement of water through hydrogeologic unit 1.

Water moves up and down in the intermediate-age rocks of hydrogeologic unit 3 and, southwest of the INL, water in hydrogeologic unit 1 probably moves down across hydrogeologic unit 2 into hydrogeologic unit 3 (fig. 24). Upward and downward movement of water in hydrogeologic unit 3 reflects changes in head with the changing thickness and transmissivity of this hydrogeologic unit. Vertical flow is downward in areas where the aquifer thickens and transmissivity increases because head decreases with depth; flow is upward in areas where the aquifer thins and transmissivity decreases because head increases with depth (fig. 24). Hydrogeologic unit 2 generally acts as an impediment to the downward movement of water from the fractured basalt of hydrogeologic unit 1 because of the smaller hydraulic conductivity of hydrogeologic unit 2. The stratigraphic interpretation of Anderson and Liszewski (1997, fig. 27) indicates that southwest of the INL hydrogeologic units 1 and 2 were uplifted. As a result of uplift, hydrogeologic unit 1 is no longer saturated and hydrogeologic unit 2 intersects the water table (fig. 24). Hydrogeologic unit 2 is less transmissive than hydrogeologic unit 1 and thus the water-table gradient steepens from about 2 to $3 \mathrm{ft} / \mathrm{mi}$ (fig. 9) upgradient of where hydrogeologic unit 2 intersects the water table to about 25 to $30 \mathrm{ft} / \mathrm{mi}$ (Lindholm and others, 1988) at and downgradient of this location. The steepening of the gradient also may be caused by the addition of underflow to the aquifer from the Big Lost River, which significantly increases the volume of water moving through this area. The steeper gradient, increased aquifer transmissivity, and increased volume of water in this area probably facilitate the downward flow of water across the younger rocks of hydrogeologic unit 2 into the intermediate-age rocks of hydrogeologic unit 3.

\section{Implications for Contaminant Transport}

The primary objective of developing a conceptual model of ground-water flow beneath the INL and vicinity is to identify features of the flow system that most affect interpretations of contaminant transport in the aquifer. The conceptual model simplifies real-world conditions and interactions through time and in space, primarily because of scaling considerations, computational constraints, and data availability. Although hydrogeologic judgment is used in determining input to the model to supplement or substitute for the lack of data, simplification invariably decreases the realism of model results. This decrease is a necessary trade off so that the model can represent large-scale, complex systems and processes that include the effects of many small-scale features and interactions.

Two of the more significant simplifications in the conceptual model are (1) representation of individual hydrogeologic units as homogeneous anisotropic porous media, and (2) implicit representation of infiltration recharge. The first simplification largely precludes simulating the tortuous character of flow that occurs naturally in heterogeneous and anisotropic fractured porous media; and the second simplification precludes realistic simulations of residual contaminant movement through the 200- to $600-\mathrm{ft}$ thick unsaturated zone, a source of contaminants that is likely to persist over a long period of time.

The conceptual model implies that most contaminant movement beneath the INL takes place in the thin, densely fractured basalts and interbedded sediment of hydrogeologic unit 1 that compose most of the upper $200 \mathrm{ft}$ of the aquifer. This hypothesis is based on (1) definition of the hydraulic properties and the inferred distribution of the three hydrogeologic units composing the aquifer, and (2) interpretation of the generalized northeast-to-southwest cross section of ground-water flow across the model area. The hypothesis is consistent with conclusions reached by earlier investigators who studied contaminant migration and aquifer characteristics at the INL and noted that waste plumes "...generally remain as relatively thin lenses within about 250 feet of the water table" (Robertson, 1974, p. 6). The current conceptual model still needs to be verified through field testing, guided by the results of future flow-and-transport modeling. 
The features of the flow system represented in the conceptual model that significantly affect contaminant transport in the aquifer at the INL and vicinity are (1) the implicit representation of infiltration recharge through the unsaturated zone that precludes realistic simulation of flow and future contaminant movement through the unsaturated zone, (2) preferential flow along highly conductive interflow zones, primarily in thin, densely fractured basalts of hydrogeologic unit 1 , implying large horizontal to vertical anisotropy and rapid lateral movement of contaminants in the upper $200 \mathrm{ft}$ of the aquifer, (3) the restricted downward movement of flow and contaminants in hydrogeologic unit 1 into the older, less conductive massive basalts of hydrogeologic unit 2 beneath the INL, implying limited dilution and dispersion of contaminants near their sources, (4) the inferred downward movement and deeper circulation of water upgradient of where the massive, less densely fractured basalt of hydrogeologic unit 2 intersects the water table southwest of the INL, implying enhanced dispersion and dilution of contaminants away from their sources and at deeper depths in the aquifer, and (5) enhanced dispersion of contaminants resulting from the spatial and temporal variability of streamflow-infiltration recharge that is in close proximity to contaminated ground water.

\section{Summary and Conclusions}

Ground-water flow in the west-central part of the eastern Snake River Plain (SRP) aquifer is described in a conceptual model that will be used in numerical simulations to evaluate contaminant transport at the Idaho National Laboratory (INL) and vicinity. The conceptual model emphasizes the effects of various geologic and hydrologic controls on the transport of contaminants at the INL.

The conceptual model encompasses an area of 1,940 $\mathrm{mi}^{2}$ and includes most of the $890 \mathrm{mi}^{2}$ of the INL. The model area extends $75 \mathrm{mi}$ from northeast to southwest and $35 \mathrm{mi}$ from northwest to southeast. The subregional scale of the conceptual model is intermediate in size between that of the Regional Aquifer System Analysis (RASA) of the eastern SRP aquifer $\left(10,800 \mathrm{mi}^{2}\right)$ and that of a local INL facility-scale model (less than about $10 \mathrm{mi}^{2}$ ).

Three hydrogeologic units were used to represent the complex stratigraphy of the aquifer in the model area. Collectively these hydrogeologic units include at least 65 basalt-flow groups, 5 andesite-flow groups, and 61 sedimentary interbeds. Three rhyolite domes in the model area extend deep enough to penetrate the aquifer and are treated as low permeability, vertical pluglike masses and are not included as part of the three primary hydrogeologic units.

Broad differences in lithology and large variations in hydraulic properties allowed the heterogeneous, anisotropic basalt-flow groups, andesite-flow groups, and sedimentary interbeds to be grouped into three hydrogeologic units that are conceptually homogeneous and anisotropic. Younger rocks, primarily of thin, densely fractured basalt, compose hydrogeologic unit 1; younger rocks, primarily of massive, less densely fractured basalt, compose hydrogeologic unit 2; and intermediate-age rocks, primarily of slightly-tomoderately altered, fractured basalt, compose hydrogeologic unit 3. Differences in hydraulic properties among adjacent hydrogeologic units result in much of the large-scale heterogeneity and anisotropy of the aquifer in the model area, and differences in horizontal and vertical hydraulic conductivity within individual hydrogeologic units result in much of the small-scale heterogeneity and anisotropy of the aquifer in the model area.

Intermediate-age rocks make up the largest volume of the aquifer. Hydrogeologic units 1 and 2 are not present in the aquifer in the northern and southern parts of the model area; in those areas, hydrogeologic unit 3 is inferred to be present at the water table. An alternative depiction of the hydrogeologic framework includes a large area of the aquifer beneath the northern and central parts of the INL where the combined sediment content of all three hydrogeologic units exceeds 11 percent and, in some cases, accounts for 25 to more than 50 percent of the composite stratigraphic section. The large sediment content of these rocks may require incorporation of a fourth hydrogeologic unit or modification of the existing hydrogeologic units to properly characterize flow and contaminant transport in the aquifer.

The aquifer is underlain by older rocks composed of intensely altered basalt and interbedded sediment. Based on surface-based electrical-resistivity surveys and stratigraphic data from boreholes at and near the INL, depth to the base of the aquifer in the model area was estimated to range from 700 to $4,800 \mathrm{ft}$ below land surface. Although stratigraphic data from 10 deep boreholes indicated that depth to the base of the aquifer ranges from 815 to $1,710 \mathrm{ft}$, the 700 to $4,800 \mathrm{ft}$ estimate was used to define the base of the aquifer because the surface-based electrical-resistivity surveys provided coverage over the entire model area.

The geometry of the aquifer is an important feature for developing models of flow and contaminant transport. Most interpretations of this geometry, particularly the thickness and distribution of hydrogeologic unit 2, depth to the base of the aquifer, and distribution of the hydrogeologic units 
south of the INL were based on very limited data and indirect measurements that are subject to considerable uncertainty. These data indicate that the three-dimensional geometry of the aquifer is very irregular. Its thickness generally increases from north to south and from west to east and is greatest south of the INL. The interpreted distribution of older rocks that underlie the aquifer indicates large changes in saturated thickness of the aquifer across the model area. Variations in thickness, depth, and attitude of individual hydrogeologic units are attributed primarily to differential subsidence and uplift.

Ground-water flow in hydrogeologic unit 1 occurs preferentially in the interflow zones of the many thin, mainly 14- to 24-ft thick, pahoehoe flows that compose this hydrogeologic unit. Aquifer tests conducted in 67 wells indicated that the hydraulic conductivity of the densely fractured rocks composing hydrogeologic unit 1 varies by more than six orders of magnitude, from 0.01 to $24,000 \mathrm{ft} / \mathrm{d}$. Almost two-thirds of these estimates are greater than $100 \mathrm{ft} / \mathrm{d}$, and about one-third are greater than 1,000 ft/d. The hydraulic conductivity of hydrogeologic unit 2 was estimated based on comparisons with massive basalts of the Columbia Plateau, measurements from flowmeter tests conducted in two wells at the Idaho Nuclear Technology and Engineering Center, and single-well aquifer tests in four wells having perforated intervals only in hydrogeologic unit 2 . These estimates ranged from 6.5 to $1,400 \mathrm{ft} / \mathrm{d}$. Individual basalt flows composing hydrogeologic unit 2 are mainly 21 - to $37-\mathrm{ft}$ thick, and the hydraulic conductivity of hydrogeologic unit 2 is presumed to be much smaller than that of hydrogeologic unit 1 because of the massive character of the individual basalt flows and the fewer number of interflow zones. Estimates of the hydraulic conductivity of the slightly altered, fractured basalt and interbedded sediment composing hydrogeologic unit 3 were based on single-well aquifer tests in 14 wells. These test results indicated that the hydraulic conductivity of these rocks ranges from about 0.32 to $24,000 \mathrm{ft} / \mathrm{d}$. Although large hydraulic conductivities were measured for hydrogeologic unit 3 , the hydraulic conductivity of hydrogeologic unit 3 is presumed to be smaller than that of hydrogeologic unit 1 because hydrogeologic unit 3 probably has fewer interflow zones and is slightly-to-moderately altered.

Estimates of porosity vary greatly because they are dependent on the methods, scales, and locations used to determine them. Core measurements indicated that the porosity of hydrogeologic unit 1 ranges from about 0.05 to 0.27 . The porosity of hydrogeologic unit 2 probably is less than that of hydrogeologic unit 1 because of the dense, massive character and fewer interflow zones associated with the rocks that compose hydrogeologic unit 2. For similar reasons, and because of alteration, the porosity of hydrogeologic unit 3 is likely to be smaller than hydrogeologic unit 1 .
Three physical and three artificial boundaries define the model area. The physical boundaries are the (1) watertable boundary, (2) base of the aquifer, and (3) northwest mountain-front boundary. The artificial boundaries are the (1) northeast boundary, (2) southeast-flowline boundary, and (3) southwest boundary. In the conceptual model ground water flow across these boundaries is represented as temporally constant or variable with spatially uniform or nonuniform flow distributions.

Flow through the unsaturated zone to the water-table boundary is represented implicitly in the conceptual model as time-averaged net infiltration recharge. Inflow across the water-table boundary, represented in the model as variable and nonuniform, occurs as (1) diffuse areal precipitation recharge $\left(70 \mathrm{ft}^{3} / \mathrm{s}\right)$ (constant and uniform), (2) streamflow-infiltration recharge from the Big Lost River $\left(95 \mathrm{ft}^{3} / \mathrm{s}\right.$ ) (variable and nonuniform), (3) wastewater return flows $\left(6 \mathrm{ft}^{3} / \mathrm{s}\right)$ (variable and nonuniform), (4) irrigation-infiltration recharge (24 ft $3 / \mathrm{s})$, and (5) release of water from storage $\left(80 \mathrm{ft}^{3} / \mathrm{s}\right)$ (variable and uniform). Flux across the water-table boundary from streamflow-infiltration recharge is about $20\left(\mathrm{ft}^{3} / \mathrm{s}\right) / \mathrm{mi}^{2}$, or more than two orders of magnitude larger than flux from precipitation recharge. Flux from streamflow-infiltration recharge during years with much larger than average streamflow was estimated to be as large as $170\left(\mathrm{ft}^{3} / \mathrm{s}\right) / \mathrm{mi}^{2}$. Because of its large flux and proximity to known sources and areas of contamination in the aquifer, streamflow-infiltration recharge from the Big Lost River is considered much more significant to contaminant transport than the other components of inflow across the water-table boundary.

The base of the aquifer is represented as a constant-flow, uniform boundary. Hydraulic conductivity of the intensely altered older rocks near the boundary, 0.002 to $0.03 \mathrm{ft} / \mathrm{d}$, was estimated to be three to four orders of magnitude smaller than that of the overlying intermediate-age rocks. Inflow across this boundary, for that part of the aquifer underlying the INL, was previously estimated at $20 \mathrm{ft}^{3} / \mathrm{s}$. This estimate was based on data from one 10,365-ft-deep corehole at the INL. Extrapolation of the estimate to the $1,940 \mathrm{mi}^{2}$ area of the conceptual model resulted in an inflow estimate of $44 \mathrm{ft}^{3} / \mathrm{s}$ or about 2 percent of the total water-budget inflow estimate. This inflow estimate represents a flux of about $0.02\left(\mathrm{ft}^{3} / \mathrm{s}\right) / \mathrm{mi}^{2}$, or about half of the flux for precipitation recharge, $0.04\left(\mathrm{ft}^{3} / \mathrm{s}\right) / \mathrm{mi}^{2}$. Because of its low flux and distance from known areas of contamination in the aquifer, the base of the aquifer, for purposes of contaminant transport modeling, can be treated as a no-flow boundary.

The northwest mountain-front boundary is represented as a constant-flow, nonuniform boundary. Inflows to the aquifer across this boundary $\left(695 \mathrm{ft}^{3} / \mathrm{s}\right)$ consist of tributary-valley underflow from the Big Lost River valley $\left(367 \mathrm{ft}^{3} / \mathrm{s}\right)$, the Little Lost River valley (226 ft $3 / \mathrm{s})$, and the Birch Creek valley $\left(102 \mathrm{ft}^{3} / \mathrm{s}\right)$. 
The northeast boundary of the model area is represented as a nonuniform, constant-flow boundary. Inflow into the aquifer across this boundary consists of underflow from the regional aquifer $\left(1,225 \mathrm{ft}^{3} / \mathrm{s}\right)$ and is the largest inflow component of the budget. Estimates of inflow across this boundary are considered fairly reliable because there is a relative abundance of information available to characterize the hydrologic conditions and hydraulic properties of the aquifer in this area.

The southeast-flowline boundary is represented as a noflow boundary and was defined by a generalized flowline derived from the RASA model and three-dimensional pathline analyses in an advective transport model.

Most of the outflow (1,731-2,343 $\left.\mathrm{ft}^{3} / \mathrm{s}\right)$ from the aquifer occurs as underflow across the southwest boundary of the study area, which is represented as a variable-flow, nonuniform boundary. The variable flow across this boundary reflects the character of large, episodic inflows from Big Lost River streamflow-infiltration recharge. Head definition for this part of the aquifer was limited to water-level measurements from six wells that are from 3 to $10 \mathrm{mi}$ from the southwest boundary; consequently, outflow estimates across this boundary are perhaps the least reliable of all the water-budget estimates.

Flow in the aquifer increases progressively in a direction downgradient of the northeast boundary. Increased flow is the result of mountain-front and tributary-valley underflows along the northwest boundary $\left(695 \mathrm{ft}^{3} / \mathrm{s}\right)$, precipitation and streamflow-infiltration recharge $\left(165 \mathrm{ft}^{3} / \mathrm{s}\right)$ across the watertable boundary, and release of water from storage $\left(80 \mathrm{ft}^{3} / \mathrm{s}\right)$. Together these additions account for more than 45 percent of the outflow across the southwest boundary. Ground-water flow beneath the INL occurs in all three hydrogeologic units. In the northern part of the INL and south of the INL, where the younger rocks of hydrogeologic units 1 and 2 are either not present or are above the water table, all flow takes place through the slightly-to-moderately altered intermediate-age rocks of hydrogeologic unit 3.

Hydraulic gradients were defined by measurements of water levels in 201 wells in the model area, 175 of which are within the boundaries of the INL. These gradients indicate that the regional direction of ground-water flow is from northeast to southwest. Hydraulic gradients are largest immediately upgradient of the northeast boundary, 27 to $60 \mathrm{ft} / \mathrm{mi}$, and southwest of the INL, 4 to $30 \mathrm{ft} / \mathrm{mi}$. Beneath the INL, gradients are much smaller, 1 to $8 \mathrm{ft} / \mathrm{mi}$, and precise definition of flow direction is difficult to determine. Flow directions in the aquifer beneath the INL vary locally from southeast to southwest and fluctuate in response to episodic recharge from streamflow infiltration. In 1984, streamflow-infiltration recharge from the Big Lost River accounted for more than 20 percent of the estimated 1980 steady-state water budget and resulted in water-level rises in the aquifer exceeding $10 \mathrm{ft}$ in places. These temporary changes in water levels alter flow directions locally and, in some extreme cases, can cause reversals in flow direction. Lateral spreading of contaminants could be strongly affected by episodic recharge and resulting temporal fluctuations in water-table gradients.

Long-term monitoring of contaminant movement in the aquifer at the INL indicates that ground-water velocities in hydrogeologic unit 1 range from 4 to $20 \mathrm{ft} / \mathrm{d}$ in areas affected by contamination south of the Test Reactor Area and the Idaho Nuclear Technology and Engineering Center. These velocities were based on presumed first-arrival times of contaminants at wells downgradient of known contaminantinput locations (injection wells) at various INL facilities. Hydraulic conductivities derived from these velocity estimates range from 500 to $5,000 \mathrm{ft} / \mathrm{d}$ for assumed effective porosities of 0.1 and 0.2 . These estimates are generally consistent with results of aquifer tests conducted in hydrogeologic unit 1 . The ground-water velocity in hydrogeologic unit 1 of from 4 to $20 \mathrm{ft} / \mathrm{d}$ probably reflects preferential flow along the many interflow zones of the thin, densely fractured basalts composing hydrogeologic unit 1 . However, because of the sometimes uncertain flow directions and gradients that are subject to fluctuations, actual flow paths may be longer and velocities higher than those estimated from first arrivals of contaminants.

Because most wells penetrate only the upper $200 \mathrm{ft}$ of the aquifer, there are few data to evaluate how hydraulic gradients and flow directions vary with depth. Two boreholes at and near the INL are equipped with dedicated piezometers to measure head changes at depth. These two boreholes are near the northeastern boundary of the INL. At one well 2 and $11 \mathrm{ft}$ increases in head at depths of 335 and $545 \mathrm{ft}$ below the water table, respectively, were measured, and at another well 0.4 and $0.3 \mathrm{ft}$ increases in head at depths of 100 and $425 \mathrm{ft}$ below the water table, respectively, were measured. The resulting vertical head differences probably are a reflection of head losses resulting from regional aquifer underflow into the layered basalts and interbedded sediments downgradient of the steep hydraulic gradient, 27 to $60 \mathrm{ft} / \mathrm{mi}$, which defines the northeast boundary of the model area.

A simplified northeast to southwest cross section showing the approximate distribution of hydrogeologic units and ground-water flow paths through the model area indicated that head decreases and then increases with depth with thickening and thinning of the aquifer in a direction downgradient of the northeast boundary. Downward flow is indicated in areas where head decreases with depth, and upward flow in areas where head increases with depth. The largest changes in vertical gradient are depicted as occurring upgradient of where hydrogeologic unit 2 is inferred to intersect the water table south of the INL. Downward movement of water across the less permeable rocks of hydrogeologic unit 2 probably occurs at this location, implying downward movement and deeper circulation of contaminants that may move offsite. 
The conceptual model implies that most contaminant movement beneath the INL probably takes place in the highly conductive rocks of hydrogeologic unit 1 that compose most of the upper $200 \mathrm{ft}$ of the aquifer. This hypothesis is based on (1) definition of the hydraulic properties and the inferred distribution of the hydrogeologic units selected to characterize flow in the aquifer, and (2) long-term observations of contaminant movement in the aquifer, the location of contaminant sources, and the history of waste-disposal practices at the INL. This hypothesis is consistent with conclusions reached by earlier investigators who studied waste behavior and aquifer characteristics at the INL and noted that waste plumes "...generally remain as relatively thin lenses within about 250 feet of the water table."

The features of the flow system represented in the conceptual model that most affect interpretations of contaminant transport at the INL and vicinity are the (1) implicit representation of infiltration recharge through the unsaturated zone, (2) preferential flow along highly conductive interflow zones, implying large horizontal to vertical anisotropy, (3) restricted downward movement of flow and contaminants in hydrogeologic unit 1 into the less conductive basalts of hydrogeologic unit 2 beneath the INL, (4) inferred downward movement and deeper circulation of water upgradient of where the massive, less densely fractured basalt of hydrogeologic unit 2 intersects the water table south of the INL, and (5) enhanced dispersion of contaminants resulting from the spatial and temporal variability of streamflowinfiltration recharge that is in close proximity to contaminated ground water.

Uncertainties were associated with all aspects of the current conceptual model. Many aspects of this model are based on interpretations or extrapolations using very limited data or indirect measurements that may be subject to considerable error. To understand contaminant transport, some uncertainties are considered to be more significant than other uncertainties. Sensitivity analysis using numerical models can be used to assess the significance of some of these uncertainties. Model performance depends on how well simulation results compare with historical records of the spatial and temporal distribution of contaminants. Confidence in a well-documented source inventory is a necessary prerequisite. However, three-dimensional field definition of contaminant concentrations in the subsurface at the INL and vicinity is lacking; so, regardless of how well transport simulations match the available field observations, independent verification of those aspects of the conceptual model that rely on interpretations of vertical flow to describe the movement of contaminants will be needed.

\section{Acknowledgments}

The authors are grateful for technical reviews of the manuscript by Wayne Belcher, Jim Bartolino, and Steve Garabedian of the USGS, and for the many helpful comments and suggestions made over the years by USGS participants of internal program reviews, especially those of Keith Prince, Devin Galloway, and Claire Tiedeman.

\section{References Cited}

Ackerman, D.J., 1991, Transmissivity of the Snake River Plain aquifer at the Idaho National Engineering Laboratory, eastern Snake River Plain: U.S. Geological Survey WaterResources Investigations Report 91-4058 (DOE/ID22097), $35 \mathrm{p}$.

Ackerman, D.J., 1995, Analysis of steady-state flow and advective transport in the eastern Snake River Plain aquifer system, Idaho: U.S. Geological Survey Water-Resources Investigations Report 94-4257 (DOE/ID-22120), 25 p.

Anderson, S.R., 1991, Stratigraphy of the unsaturated zone and uppermost part of the Snake River Plain aquifer at the Idaho Chemical Processing Plant and Test Reactors Area, Idaho National Engineering Laboratory, Idaho: U.S. Geological Survey Water-Resources Investigations Report 91-4010 (DOE/ID-22095), 71 p.

Anderson, S.R., Ackerman, D.J., Liszewski, M.J., and Freiburger, R.M., 1996a, Stratigraphic data for wells at and near the Idaho National Engineering Laboratory, Idaho: U.S. Geological Survey Open-File Report 96-248 (DOE/ID22127), 27 p. and 1 diskette.

Anderson, S.R., Kuntz, M.A., and Davis, L.C., 1999, Geologic controls of hydraulic conductivity in the Snake River Plain aquifer at and near the Idaho National Engineering and Environmental Laboratory, Idaho: U.S. Geological Survey Water-Resources Investigations Report 99-4033 (DOE/ID22155), $38 \mathrm{p}$.

Anderson, S.R. and Liszewski, M.J., 1997, Stratigraphy of the unsaturated zone and the Snake River Plain Aquifer at and near the Idaho National Engineering Laboratory, Idaho: U.S. Geological Survey Water-Resources Investigations Report 97-4183 (DOE/ID-22142), 65 p.

Anderson, S.R., Liszewski, M.J., and Ackerman, D.J., 1996b, Thickness of surficial sediment at and near the Idaho National Engineering Laboratory, Idaho: U.S. Geological Survey Open-File Report 96-330 (DOE/ID-22128), 16 p. 
Anderson, S.R., Liszewski, M.J., and Cecil, L.D., 1997, Geologic ages and accumulation rates of basalt-flow groups and sedimentary interbeds in selected wells at the Idaho National Engineering Laboratory, Idaho: U.S. Geological Survey Water-Resources Investigations Report 97-4010 (DOE/ID-22134), 39 p.

Barraclough, J.T., and Jensen, R.G., 1976, Hydrologic data for the Idaho National Engineering Laboratory site, Idaho, 1971 to 1973: U.S. Geological Survey Open-File Report 75-318 (IDO-22055), 52 p.

Barraclough, J.T., Lewis, B.D., and Jensen, R.G., 1981, Hydrologic conditions at the Idaho National Engineering Laboratory, Idaho, emphasis; 1974-1978: U.S. Geological Survey Open-File Report 81-526, (IDO-22060), 116 p.

Barraclough, J.T., Robertson, J.B., Janzer, V.J., and Saindon, L.G., 1976, Hydrology of the solid waste burial ground, as related to the potential migration of radionuclides, Idaho National Engineering Laboratory: U.S. Geological Survey Open-File Report 76-471, (IDO-22056), 183 p.

Barraclough, J.T., Teasdale, W.E., and Jensen, R.G., 1967, Hydrology of the National Reactor Testing Station, Idaho, 1965: U.S. Geological Survey Open-File Report, (IDO22048), $107 \mathrm{p}$.

Barraclough, J.T., Teasdale, W.E., Robertson, J.B., and Jensen, R.G., 1967, Hydrology of the National Reactor Testing Station, Idaho, 1966: U.S. Geological Survey Open-File Report, (IDO-22049), 95 p.

Bartholomay, R.C., Orr, B.R., Liszewski, M.J., and Jensen, R.G., 1995, Hydrologic conditions and distribution of selected radiochemical and chemical constituents in water, Snake River Plain aquifer, Idaho National Engineering Laboratory, Idaho, 1989 through 1991: U.S. Geological Survey Water-Resources Investigations Report, 95-4175 (DOE/ID-22123), $47 \mathrm{p}$.

Bartholomay, R.C., Tucker, B.J., Ackerman, D.J., and Liszewski, M.J., 1997, Hydrologic conditions and distribution of selected radiochemical and chemical constituents in water, Snake River Plain aquifer, Idaho National Engineering Laboratory, Idaho, 1992 through 1995: U.S. Geological Survey Water-Resources Investigations Report, 97-4086 (DOE/ID-22137), $57 \mathrm{p}$.

Bartholomay, R.C., Tucker, B.J., Davis, L.C., and Greene, M.R., 2000, Hydrologic conditions and distribution of selected constituents in water, Snake River Plain aquifer, Idaho National Engineering and Environmental Laboratory, Idaho, 1996 through 1998: U.S. Geological Survey WaterResources Investigations Report 00-4192 (DOE/ID-22167), $52 \mathrm{p}$.
Batchelder, H.M., 1981, Industrial waste management information for 1980 and year-to-date: EG\&G Idaho, Inc., IDO10057(80), $103 \mathrm{p}$.

Beasley, T.M., 1995, Inventory of site-derived ${ }^{36} \mathrm{Cl}$ in the Snake River Plain aquifer, Idaho National Engineering Laboratory, Idaho: Department of Energy Report EML-567, $51 \mathrm{p}$.

Becker, B.H., Burgess, J.D., Holdren, K.J., Jorgenson, D.K., Magnuson, S.O., and Sondrup, A.J., 1998, Interim risk assessment and containment screening for the Waste Area Group 7 remedial investigation: Lockheed Martin Idaho Technologies Company, DOE/ID-10569, Draft Rev. 1.

Bennett, C.M., 1990, Streamflow losses and ground-water level changes along the Big Lost River at the Idaho National Engineering Laboratory, Idaho: U.S. Geological Survey Water-Resources Investigations Report 90-4067 (DOE/ ID-22091), 49 p.

Bestland, E.A., Link, P.K., Lanphere, M.A., and Champion, D.E., 2002, Paleoenvironments of sedimentary interbeds in the Pliocene and Quaternary Big Lost Trough, eastern Snake River Plain, Idaho, in Link, P.K., and Mink, L.L., eds., Geology, hydrogeology, and environmental remediation: Idaho National Engineering and Environmental Laboratory, Eastern Snake River Plain, Idaho: Boulder, Colo., Geological Society of America Special Paper 353, p. 27-44.

Bishop, C.W., 1991, Hydraulic properties of vesicular basalt: Tucson, University of Arizona, unpublished M.S. thesis, $115 \mathrm{p}$.

Blackwell, D.D., Kelley, S., and Steele, J.L., 1992, Heat flow modeling of the Snake River Plain, Idaho: D.O.E. contractor report no. EGG-NPR-10790, 109 p.

Brennan, T.S., Lehmann, A.K., O'Dell, I., and Campbell, A.M., 2004, Water resources data, Idaho, water year 2003, Volume 1. Great Basin and Snake River Basin above King Hill: U.S. Geological Survey Water-Data Report ID-03-1, $237 \mathrm{p}$.

Bukowski, J.M., Bullock, H., and Neher, E.R., 1998, Site conceptual model-1997 activities, data analysis, and interpretation for Test Area North, Operable Unit 1-07B: Lockheed Martin Technologies Company Report INEEL/EXT-9800575 Rev. 0, [variously paged].

Busenberg, E., Plummer, L.N., and Bartholomay, R.C., 2001, Estimated age and source of the young fraction of ground water at the Idaho National Engineering and Environmental Laboratory: U.S. Geological Survey Water-Resources Investigations Report 01-4265 (DOE/ID-22177), 144 p. 
Busenberg, E., Plummer, L.N., Doughten, M.W., Widman, P.K., and Bartholomay, R.C., 2000, Chemical and isotopic composition and gas concentrations of ground water and surface water from selected sites at and near the Idaho National Engineering and Environmental Laboratory, Idaho, 1994-97: U.S. Geological Survey Open-File Report 00-81 (DOE/ID-22164), $51 \mathrm{p}$.

Busenberg, E., Weeks, E.P., Plummer, L.N., and Bartholomay, R.C., 1993, Age dating ground water by use of chlorofluorocarbons $\left(\mathrm{CCl}_{3} \mathrm{~F}\right.$ and $\left.\mathrm{CCl}_{2} \mathrm{~F}_{2}\right)$, and distribution of chlorofluorocarbons in the unsaturated zone, Snake River Plain Aquifer, Idaho National Engineering Laboratory, Idaho: U.S. Geological Survey Water-Resources Investigations Report 93-4054 (DOE/ID-22107), 47 p.

Cecil, L.D., Pittman, J.R., Beasley, T.M., Michel, R.L., Kubik, P.W., Sharma, P., Fehn, U., and Gove, H.E., 1992, Water infiltration rates in the unsaturated zone at the Idaho National Engineering Laboratory estimated from chlorine36 and tritium profiles, and neutron logging, in Kharaka, Y.K, and Maest, A.S., eds.: Balkama, Rotterdam, Proceedings of the 7th International Symposium on Water-Rock Interaction, Park City, Utah, July 13-18, 1992, p. 709-714.

Cecil, L.D., Welhan, J.A., Green, J.R., Frape, S.K., and Sudicky, E.R., 2000, Use of chlorine-36 to determine regional-scale aquifer dispersivity, eastern Snake River Plain aquifer, Idaho/USA: Nuclear Instruments and Methods in Physics Research B 172, p. 679-687.

Clawson, K.L., Start, G.E., and Ricks, N.R., 1989, Climatography of the Idaho National Engineering Laboratory (2d ed.): National Oceanic and Atmospheric Administration, DOE/ID-12118, $155 \mathrm{p}$.

Crosthwaite, E.G., 1973, A Progress report on results of test drilling and ground-water investigations of the Snake Plain aquifer, southeastern Idaho; Part 1, Mud Lake region 1969-70; Part 2, Observation wells south of Arco and west of Aberdeen: Idaho Department of Water Administration, Water Information Bulletin 32, $60 \mathrm{p}$.

Crosthwaite, E.G., Thomas, C.A., and Dyer, K.L., 1970, Water Resources in the Big Lost River Basin, south-central Idaho: U.S. Geological Survey Open-File Report, 109 p.

Fetter, C.W., 1994, Applied hydrology (3d ed.): New York, Macmillan College Publishing Company, 691 p.

Frederick, D.B., and Johnson, G.S., 1996, Estimation of hydraulic properties and development of a layered conceptual model for the Snake River Plain aquifer at the Idaho National Engineering Laboratory, Idaho: Idaho Water Resources Research Institute, Research Technical Completion Report, variously paged.
French, D.L., Tallman, R.E., and Taylor, K.A., 1999, Radioactive waste information for 1998 and record-to-date: Lockheed Martin Idaho Technologies, DOE/ID10054(98), 134 p.

Fromm, J.M., Hackett, W.R., and Stephens, J.D., 1994, Primary mineralogy and alteration of basalts and sediments in drillcores from the Idaho National Engineering Laboratory, eastern Snake River Plain [abs.]: International Symposium on the Observation of the Continental Crust Through Drilling, 7th, Santa Fe, N. Mex., April 25-30, 1994, Abstracts, unpaged.

Garabedian, S.P., 1986, Application of a parameter-estimation technique to modeling the regional aquifer underlying the eastern Snake River Plain, Idaho: U.S. Geological Survey Water-Supply Paper 2278, 60 p.

Garabedian, S.P., 1992, Hydrology and digital simulation of the regional aquifer system, eastern Snake River Plain, Idaho: U.S. Geological Survey Professional Paper 1408-F, $102 \mathrm{p} ., 10 \mathrm{pl}$.

Gelhar, L.W., Welty, C., and Rehfeldt, K.R., 1992, A critical review of data on field-scale dispersion in aquifers: Water Resources Research, v. 28, no. 7, p. 1955-1974.

Geslin, J.K., Link, K.L., Riesterer, J.W., Kuntz, M.A., and Fanning, C.M., 2002, Pliocene and Quaternary stratigraphic architecture and drainage systems of the Big Lost Trough, northeastern Snake River Plain, Idaho, in Link, P.K., and Mink, L.L., eds.: Geology, hydrogeology, and environmental remediation: Idaho National Engineering and Environmental Laboratory, Eastern Snake River Plain, Idaho: Geological Society of America Special Paper 353, Boulder, Colo., p. 11-26.

Gianniny, G.L., Geslin, J.K., Riesterer, J.W., Link, P.K., and Thackray, G.D., 1997, Quaternary surficial sediments near Test Area North (TAN) northeastern Snake River Plain —an actualistic guide to aquifer characterization, in Sharma, S., and Hardcastle, J.H., eds., Symposium on engineering geology and geotechnical engineering, 32d, Boise, Idaho, March 26-28, 1997, Proceedings: Pocatello, Idaho, Idaho State University College of Engineering, p. 29-44.

Goode, D.J., and Konikow, L.F., 1990a, Apparent dispersion in transient groundwater flow: Water Resources Research, v. 26 , no. 10 , p. $2339-2351$.

Goode, D.J., and Konikow, L.F., 1990b, Reevaluation of largescale dispersivities for a waste chloride plume-Effects of transient flow, in Kovar, Karel, ed., ModelCARE 90: Calibration and Reliability in Groundwater Modeling, Proceedings of the conference, The Hague, September 1990), IAHS Publication no. 195, p. 417-426.

Goodell, S.A., 1988, Water use on the Snake River Plain, Idaho and eastern Oregon: U.S. Geological Survey Professional Paper 1408-E, 51 p. 
Hughes, S.S., Smith, R.P., Hackett, W.R., and Anderson, S.R., 1999, Mafic volcanism and environmental geology of the eastern Snake River Plain, Idaho, in Hughes S.S. and Thackray, G.D., eds., Guidebook to the geology of eastern Idaho: Idaho Museum of Natural History, p. 143-168.

Johnson, T.M., Roback, R.C., McLing, T.L., Bullen, T.D., DePaolo, D.J., Doughty, C., Hunt, R.J., Smith, R.W., Cecil, L.D., and Murrell, M.T., 2000, Groundwater "fast paths" in the Snake River Plain aquifer-Radiogenic isotope ratios as natural groundwater tracers: Geology, v. 28, no. 10, p. 871-874.

Jones, P.H., 1961, Hydrology of waste disposal, National Reactor Testing Station, Idaho_-an interim report: U.S. Geological Survey (IDO-22042-USGS), 152 p.

Jones, P.H., 1963, The velocity of ground-water flow in basalt aquifers of the Snake River Plain, Idaho: International Association of Scientific Hydrology, no. 64, p. 224-234.

Kjelstrom, L.C., 1986, Flow characteristics of the Snake River and water budget for the Snake River Plain, Idaho and eastern Oregon: U.S. Geological Survey Hydrologic Investigations Atlas HA-680, scale 1:1,000,000, 2 sheets.

Kjelstrom, L.C., 1995, Streamflow gains and losses in the Snake River and ground-water budgets for the Snake River Plain, Idaho and eastern Oregon: U.S. Geological Survey Professional Paper 1408-C, 47 p.

Kjelstrom, L.C., and Berenbrock, C., 1996, Estimated 100year peak flows and flow volumes in the Big Lost River and Birch Creek at the Idaho National Engineering Laboratory, Idaho: U.S. Geological Survey Water Resources Investigations Report 96-4163, 23 p.

Knutson, C.F., McCormick, K.A., Crocker, J.C., Glenn, M.A., and Fishel, M.L., 1992, 3D RWMC vadose zone modeling (including FY-89 to FY-90 basalt characterization results): EG\&G Idaho, Inc., Report EGG-ERD-10246 [variously paged].

Knutson, C.F., McCormick, K.A., Smith, R.P., Hackett, W.R., O’Brien, J.P., and Crocker, J.C., 1990, FY-89 RWMC vadose zone basalt characterization: EG\&G Idaho, Inc. Report EGG WM-8949 [variously paged].

Kuntz, M.A., Covington, H.R., and Schorr, L.J., 1992, An overview of basaltic volcanism of the eastern Snake River Plain, Idaho, in Link, P.K., Kuntz, M.A., and Platt, L.P., eds., Regional geology of eastern Idaho and western Wyoming: Geological Society of America Memoir 179, p. 227267.

Kuntz, M.A., and Dalrymple, G.B., 1979, Geology, geochronology, and potential volcanic hazards in the Lava RidgeHell's Half Acre area, eastern Snake River Plain, Idaho: U.S. Geological Survey Open-File Report 79-1657, 70 p.
Kuntz, M.A., Skipp, Betty, Lanphere, M.A., Scott, W.E., Pierce, K.L., Dalrymple, G.B., Champion, D.E., Embree, G.F., Page, W.R., Morgan, L.A., Smith, R.P., Hackett, W.R., and Rodgers, D.W., 1994, Geologic map of the Idaho National Engineering Laboratory and adjoining areas, eastern Idaho: U.S. Geological Survey Miscellaneous Investigations Map I-2330, scale 1:100,000.

Lanphere, M.A., Champion, D. E., and Kuntz, M.A., 1993, Petrography, age, and paleomagnetism of basalt lava flows in coreholes Well 80, NRF 89-04, NRF 89-05, and ICPP 123, Idaho National Engineering Laboratory: U.S. Geological Survey Open-File Report 93-327, 40 p.

Lanphere, M.A., Kuntz, M.A., and Champion, D.E., 1994, Petrography, age, and paleomagnetism of basalt lava flows in coreholes at Test Area North (TAN), Idaho National Engineering Laboratory: U.S. Geological Survey Open-File Report 94-686, 49 p.

Lewis, B.D., and Jensen, R.G., 1985, Hydrologic conditions at the Idaho National Engineering Laboratory, Idaho, 1979-1981 update: U.S. Geological Survey Hydrologic Investigations Atlas HA-674, 2 sheets.

Lindholm, G.F., 1996, Summary of the Snake River Plain Regional Aquifer-System Analysis in Idaho and eastern Oregon: U.S. Geological Survey Professional Paper 1408-A, 59 p.

Lindholm, G.F., Garabedian, S.P., Newton, G.D., and Whitehead, R.L., 1988 [1987], Configuration of the water table and depth to water, spring 1980, water-level fluctuations, and water movement in the Snake River Plain regional aquifer system, Idaho and eastern Oregon: U.S. Geological Survey Hydrologic Investigations Atlas HA-703, scale $1: 500,000$.

Luo, S., Ku, T., Roback, R., Murrell, M., and McLing, T., 2000, In-situ radionuclide transport and preferential groundwater flows at INL (Idaho)—Decay-series disequilibrium studies, Geochimica et Cosmochimica Acta, v. 64, no. 5, p. 867-881.

Magnuson, S.O., and Sondrup, A.J., 1998, Development, calibration, and predictive results of a simulator for subsurface pathway fate and transport of aqueous- and gaseousphase contaminants in the Subsurface Disposal Area at the Idaho National Engineering and Environmental Laboratory: INEEL/EXT-97-00609, Lockheed Martin Idaho Technologies Company, Idaho Falls, Idaho, [variously paged].

Mann, L.J., 1986, Hydraulic properties of rock units and chemical quality of water for INEL-1, a 10,365-foot deep test hole drilled at the Idaho National Engineering Laboratory, Idaho: U.S. Geological Survey Water-Resources Investigations Report 86-4020 (IDO-22070), 23 p. 
Mann, L.J., and Beasley, T.M., 1994, Iodine-129 in the Snake River Plain aquifer at and near the Idaho National Engineering Laboratory, Idaho, 1990-91: U.S. Geological Survey Water-Resources Investigations Report 94-4053 (DOE/ID22115), 27 p.

Mann, L.J., and Knobel, L.L., 1987, Purgeable organic compounds in ground-water at the Idaho National Engineering Laboratory, Idaho: U.S. Geological Survey Open-File Report 87-766 (DOE/ID-22074), 23 p.

Mazurek, J., McCurry, M., and Portner, R., 2004, Alteration characteristics and authigenic mineralogy of basalts in borehole middle 1823, eastern Snake River Plain, SE Idaho: Geological Society of America, 2004 Abstracts with Programs, v. 36, no. 4, p. 86.

McCarthy, J.M., Arnett, R.C., Neupauer, R.M., Rohe, M.J., and Smith, C., 1995, Development of a regional groundwater flow model for the area of the Idaho National Engineering Laboratory, eastern Snake River Plain aquifer: Lockheed Idaho Technologies Company, INEL-95-0169, Revision 1, variously paged.

McCurry, M., Hackett, W.R., and Hayden, 1999, Cedar Butte and cogenetic Quaternary rhyolite domes of the eastern Snake River Plain, in Hughes, S.S., and Thackray G.D., eds., Guidebook to the geology of eastern Idaho: Idaho Museum of Natural History, p. 169-179.

McElroy, Deborah, and Hubbell, Joel, 1990, Hydrologic and physical properties of sediments at the Radioactive Waste Management Complex, Idaho National Engineering Laboratory: EG\&G Idaho, Inc., Informal Report EGG-BG-9147, [variously paged].

Morin, R.H., Barrash, Warren, Paillet, F.L., and Taylor, T.A., 1993, Geophysical logging studies in the Snake River Plain aquifer at the Idaho National Engineering Laboratory-wells 44, 45, and 46: U.S. Geological Survey WaterResources Investigations Report 92-4184, 44 p.

Morris, D.A., Barraclough, J.T., Chase, G.H., Teasdale, W.E., and Jensen, R.G., 1965, Hydrology of subsurface waste disposal, National Reactor Testing Station, Idaho, Annual progress report, 1964: U.S. Geological Survey (IDO-22047USGS), 186 p.

Morris, D.A., Teasdale, W.E., Chase, G.H., Hogenson, G.M., Barraclough, J.T., Shuter, E., Ralston, D.A., and Jensen, R.G., 1964, Hydrology of subsurface waste disposal, National Reactor Testing Station, Idaho, Annual progress report, 1963: U.S. Geological Survey (IDO-22046-USGS), $97 \mathrm{p}$.
Morse, L.H., and McCurry, M., 1997, Possible correlations between basalt alteration and the effective base of the Snake River Plain aquifer at the Idaho National Engineering and Environmental Laboratory, in Sharma, S., and Hardcastle, J.H., eds., Symposium on engineering geology and geotechnical engineering, 32d, Boise, Idaho, March 26-28, 1997 , Proceedings: Pocatello, Idaho, Idaho State University College of Engineering, p. 1-14.

Morse, L.H., and McCurry, M., 2002, Genesis of alteration of Quaternary basalt within a portion of the eastern Snake River Plain aquifer, in Link, P.K., and Mink, L.L., eds., Geology, hydrogeology, and environmental remediation: Idaho National Engineering and Environmental Laboratory, Eastern Snake River Plain, Idaho: Geological Society of America Special Paper 353, Boulder, Colo., p. 213-224.

Mundorff, M.J., Crosthwaite, E.G., and Kilburn, Chabot, 1964, Ground water for irrigation in the Snake River basin in Idaho: U.S. Geological Survey Water-Supply Paper 1654, $224 \mathrm{p}$.

Nace, R.L., Stewart, J.W., Walton, W.C., and others, 1959, Geography, geology, and water resources of the National Reactor Testing Station, Idaho_-Part 3. Hydrology and water resources: U.S. Geological Survey Open-File Report (IDO-22034), $253 \mathrm{p}$.

Nace, R.L., Voegeli, P.T., Jones, J.R., and Deutsch, Morris, 1975, Generalized geologic framework of the National Reactor Testing Station, Idaho: U.S. Geological Survey Professional Paper 725-B, 49 p.

Newton, G.D., 1978, Application of a simulation model to the Snake River Plain aquifer: Moscow, Idaho, University of Idaho, unpublished Master of Science thesis, $82 \mathrm{p}$.

Norvitch, R.F., Thomas, C.A., and Madison, R.J., 1969, Artificial recharge to the Snake Plain aquifer; an evaluation of potential and effect: Boise, Idaho Department of Reclamation, Water Information Bulletin 12, 59 p.

Olmstead, F.H., 1962, Chemical and physical character of ground water in the National Reactor Testing Station, Idaho: U.S. Atomic Energy Commission, Idaho Operations Office Publication IDO-22043-USGS, 142 p.

Orr, B.R., and Cecil, L.D., 1991, Hydrologic conditions and distribution of selected radiochemical and chemical constituents in water, Snake River Plain aquifer, Idaho National Engineering Laboratory, Idaho, 1986 through 1988: U.S. Geological Survey Water Resources Investigations Report, 91-4047, DOE/ID-22096, 56 p. 
Perkins, K.S., 2003, Measurement of sedimentary interbed hydraulic properties and their hydrologic influence near the Idaho Nuclear Technology and Engineering Center at the Idaho National Engineering and Environmental Laboratory: U.S. Geological Survey Water- Resources Investigations Report, 03-4048 (DOE/ID-22183), 19 p.

Perkins, K.S., and Nimmo, J.R., 2000, Measurement of hydraulic properties of the B-C interbed and their influence on contaminant transport in the unsaturated zone at the Idaho National Engineering and Environmental Laboratory: U.S. Geological Survey Water- Resources Investigations Report, 00-4073 (DOE/ID-22170), 30 p.

Pierce, K.L., and Morgan, L.A., 1992, The track of the Yellowstone hot spot: Volcanism, faulting, and uplift, in Link, P.K., Kuntz, M.A., and Platt, L.B., eds., Regional Geology of Eastern Idaho and Western Wyoming: Geological Society of America Memoir 179, p. 1-53.

Pittman, J.R., Jensen, R.G., and Fischer, P.R., 1988, Hydrologic conditions at the Idaho National Engineering Laboratory, 1982 to 1985: U.S. Geological Survey WaterResources Investigations Report 89-4008 (DOE/ID-22078), $73 \mathrm{p}$.

Robertson, J.B., 1974, Digital modeling of radioactive and chemical waste transport in the Snake River Plain aquifer at the National Reactor Testing Station, Idaho: U.S. Geological Survey Open-File Report (IDO-22054), 41 p.

Robertson, J.B., 1977, Numerical modeling of subsurface radioactive solute transport from waste-seepage ponds at the Idaho National Engineering Laboratory: U.S. Geological Survey Open-File Report 76-717 (IDO-22057), 68 p.

Robertson, J.B., Schoen, Robert, and Barraclough, J.T., 1974, The influence of liquid waste disposal on the geochemistry of water at the National Reactor Testing Station, Idaho: 1952-70: U.S. Geological Survey Open-File Report (IDO-22053), $231 \mathrm{p}$.

Schafer-Perini, A.L., 1993, Test Area North groundwater remedial investigation/feasibility study contaminant fate and transport modeling results: ER WAG1-21, EG\&G Idaho, Inc., Idaho National Engineering and Environmental Laboratory, Idaho Falls, Idaho, [variously paged].

Sorenson, K.S., Peterson, L.N., Hinchee, R.E., and Ely, R.L., 2000, An evaluation of aerobic trichloroethene attenuation using first-order rate estimation: Bioremediation Journal, v. 4 , no. 4 , p. $337-357$.

Sorenson, K.S., Jr., Wylie, A.H., and Wood, T.R., 1996, Test Area North site conceptual model and proposed hydrogeologic studies: Operable Unit 1-07B, INEL-96/0105, variously paged.
Spear, D.B., and King J.S., 1982, The geology of Big Southern Butte, Idaho, in Bonnichsen, B., and Breckenridge, R.M., eds., Cenozoic geology of Idaho: Bulletin 26 of the Idaho Bureau of Mines and Geology, p. 395-403.

Spinazola, J.M., 1994, Geohydrology and simulation of flow and water levels in the aquifer system in the Mud Lake area of the eastern Snake River Plain, eastern Idaho: U.S. Geological Survey Water-Resources Investigations Report 93-4227, $78 \mathrm{p}$.

Stearns, H.T., Bryan, L.L., and Crandall, Lynn, 1939, Geology and water resources of the Mud Lake basin, Idaho, including the Island Park area: U.S. Geological Survey WaterSupply Paper 818, 125 p.

Stearns, H.T., Crandall, Lynn, and Steward, W.G., 1938, Geology and ground-water resources of the Snake River Plain in southeastern Idaho: U.S. Geological Survey Water-Supply Paper 774, 268 p.

Stone, M.A.J., Mann, L.J., and Kjelstrom, L.C., 1992, Statistical summaries of streamflow data for selected gaging stations on and near the Idaho National Engineering Laboratory, Idaho, through September 1990: U.S. Geological Survey Water-Resources Investigations Report 92-4196, DOE/ID-22109, 35 p.

Welhan, J.A., Clemo, T.M., and Gégo, E.L., 2002a, Stochastic simulation of aquifer heterogeneity in a layered basalt aquifer system, eastern Snake River Plain, Idaho, in Link, P.K., and Mink, L.L., eds., Geology, hydrogeology, and environmental remediation: Idaho National Engineering and Environmental Laboratory, Eastern Snake River Plain, Idaho: Boulder, Colo., Geological Society of America Special Paper 353, p. 225-247.

Welhan, J.A., Johannesen, C.M., Reeves, K.S., Clemo, T.M., Glover, J.A., and Bosworth, K.W., 2002b, Morphology of inflated pahoehoe lavas and spatial architecture of their porous and permeable zones, eastern Snake River Plain, Idaho, in Link, P.K., and Mink, L.L., eds., Geology, hydrogeology, and environmental remediation: Idaho National Engineering and Environmental Laboratory, Eastern Snake River Plain, Idaho: Boulder, Colo., Geological Society of America Special Paper 353, p. 135-150.

Welhan, J.A., and Wylie, A.H., 1997, Stochastic modeling of hydraulic conductivity in the Snake River Plain aquifer: 2. Evaluation of lithologic controls at the core and borehole scales, in Sharma, S., and Hardcastle, J.H., eds., Symposium on engineering geology and geotechnical engineering, 32d, Boise, Idaho, March 26-28, 1997, Proceedings: Pocatello, Idaho, Idaho State University College of Engineering, p. 93-107. 
Wetmore, P.H., Hughes, S.S., and Anderson, S.R., 1997, Model morphologies of subsurface Quaternary basalts as evidence for a decrease in the magnitude of basaltic magmatism at and near the Idaho National Engineering and Environmental Laboratory, Idaho, in Sharma, S., and Hardcastle, J.H., eds., Symposium on engineering geology and geotechnical engineering, 32d, Boise, Idaho, March 26-28, 1997, Proceedings: Pocatello, Idaho, Idaho State University College of Engineering, p. 45-58.

White, S.S., 1975, Idaho National Engineering Laboratory industrial waste management information system for 1974 and record-to-date: U.S. Atomic Energy Commission, Idaho Operations Office, IDO-10057(74), 69 p.

Whitehead, R.L., 1986, Geohydrologic framework of the Snake River Plain, Idaho and eastern Oregon: U.S. Geological Survey Hydrologic Investigations Atlas HA-681, scale $1: 1,000,000,3$ sheets.

Whitehead, R.L., 1992, Geohydrologic framework of the Snake River Plain regional aquifer system, Idaho and eastern Oregon: U.S. Geological Survey Professional Paper 1408-B, 32 p.
Winfield, K.A., 2003, Spatial variability of sedimentary interbed properties near the Idaho Nuclear Technology and Engineering Center at the Idaho National Engineering and Environmental Laboratory, Idaho: U.S. Geological Survey Water Resources Investigations Report 2003-4142, 36 p.

Winfield, K.A., 2005, Development of property-transfer models for estimating the hydraulic properties of deep sediments at the Idaho National Engineering and Environmental Laboratory, Idaho: U.S. Geological Survey Scientific Investigations Report 2005-5114, 59 p.

Wood, T.R., and Norrell, G.T., 1996, Integrated large-scale aquifer pumping and infiltration tests, groundwater pathways, OU 7-06, summary report: INEL-96/0256, Rev. 0, variously paged.

Zohdy, A.A.R., 1974, Electrical methods: in Zohdy, A.A.R., Eaton, G.P., and Mabey, D.R., Application of surface geophysics to ground-water investigations: U.S. Geological Survey Techniques of Water-Resources Investigations, book 2, chap. D1, p. 5-66. 


\section{Appendix A. A Brief History of Wastewater-Disposal Practices at the Idaho National Laboratory}

Wastewater-disposal sites at Test Area North (TAN), the Test Reactor Area (TRA), and the Idaho Nuclear Technology and Engineering Center (INTEC) were the principal sources of radioactive- and chemical-waste constituents in water in the Snake River Plain aquifer. In the past, wastewaterdisposal sites have included lined evaporation ponds, unlined infiltration ponds and ditches, drain fields, and disposal wells. Waste materials buried at the Radioactive Waste Management Complex (RWMC) also are sources of some constituents in ground water. A brief history of wastewater-disposal practices at various facilities on the INL is provided below. Most of this historical information is documented in a report by Bartholomay and others (2000).

Test Area North-From 1953 to 1972, low-level radioactive, chemical, and sanitary wastewater was discharged at TAN (fig. 1) into the Snake River Plain aquifer through a 310-ft-deep disposal well. In 1972, the disposal well was replaced by a 35 -acre infiltration pond. No records are available on the amount of radioactivity in wastewater discharged at TAN before 1959. During 1959-93, about $61 \mathrm{Ci}$ of radioactivity was in wastewater discharged to the disposal well and infiltration pond. Of this amount, about $20 \mathrm{Ci}$ was discharged to the disposal well in 1968 and 1969 in response to problems with an evaporator used to reduce the volume of wastewater. No radioactive wastewater was discharged to TAN disposal sites since 1993.

Test Reactor Area-Since 1952, wastewater containing low-level radioactive contaminants was discharged to infiltration and evaporation ponds at the TRA. The wastewater was discharged to a series of infiltration ponds until 1993, when two lined evaporation ponds replaced the infiltration ponds to prevent the wastewater from entering the aquifer. The average annual discharge to the infiltration and evaporation ponds was about 116 Mgal during 1960-98 (Bartholomay and others, 2000, p. 10). Radioactive constituents in the wastewater discharged to the ponds included tritium (about 10,000 Ci), strontium-90 (about $93 \mathrm{Ci}$ ), cesium-137 (about $138 \mathrm{Ci}$ ), and cobalt-60 (about $438 \mathrm{Ci}$ ). During 1974-79, about 10 percent of the radioactivity in wastewater discharged to the subsurface was attributed to tritium; in 1980, about 50 percent was attributed to tritium; and in 1981-85, about 90 percent was attributed to tritium (Pittman and others, 1988, p. 22). Since 1986, about 97 percent of the radioactivity in wastewater discharged at the TRA was attributed to tritium.

The radioactive-waste infiltration ponds also were used for disposal of wastewater containing nonradioactive chemical wastes until 1962, when a chemical-waste infiltration pond was constructed. This infiltration pond was used principally for disposal of chemical wastewater from an ion-exchange system at the TRA. The average annual discharge to this pond was about 17.5 Mgal for the period 1962-98. Sulfate and sodium hydrate were the predominant constituents in the wastewater.

Nonradioactive cooling-tower wastewater was discharged to the radioactive-waste infiltration ponds from 1952 to 1964 , to the Snake River Plain aquifer through a 1,267-ft-deep disposal well from 1964 until 1982, and into two cold-waste infiltration ponds from 1982 to present. Until 1972, coolingtower wastewater contained concentrations of dissolved chromium used as a rust inhibitor. The average annual discharge to the well and the infiltration ponds was about 226 Mgal during 1964-95 and about 181 Mgal during 1996-98.

\section{Idaho Nuclear Technology and Engineering}

Center-From 1952 to February 1984, most of the low-level radioactive, chemical, and sanitary wastewater at the INTEC (fig. 1) was discharged to the Snake River Plain aquifer through a 600 -ft-deep disposal well. The average annual discharge of wastewater to the well was about $363 \mathrm{Mgal}$ (Pittman and others, 1988, p. 24). Beginning in 1984, two infiltration ponds were used for wastewater disposal. An average of $442 \mathrm{Mgal}$ of wastewater was discharged annually to the well and infiltration ponds during 1962-98. The annual discharge to the well and ponds ranged from a low of $260 \mathrm{Mgal}$ in 1963 to a high of $665 \mathrm{Mgal}$ in 1993.

Tritium has accounted for more than 90 percent of the radioactivity in wastewater discharged at the INTEC since 1970. More than 20,000 Ci of tritium in wastewater was discharged to the disposal well and infiltration ponds at the INTEC.

Radioactive Waste Management Complex-Solid and liquid radioactive and chemical wastes were buried in trenches and pits at the Subsurface Disposal Area (SDA) at the RWMC (fig. 1) since 1952. These constituents include transuranic wastes (buried in trenches until 1970), other radiochemical and inorganic chemical constituents, and organic compounds. Before 1970, little or no sediment was retained between the excavation bottoms and the underlying basalt. Since 1970, a layer of sediment was retained in excavations to inhibit downward migration of waste constituents.

About 9,600 Ci of plutonium-238, 160,000 Ci of plutonium-239, 38,000 Ci of plutonium-240, 960,000 Ci of plutonium-241, and 365,000 $\mathrm{Ci}$ of americium-241 were buried in the SDA during 1952-70 (Becker and others, 1998, table 4-1). An estimated 88,400 gal of organic waste was buried before 1970 (Mann and Knobel, 1987, p. 1). These buried wastes included about 24,400 gal of carbon tetrachloride; $39,000 \mathrm{gal}$ of lubricating oil; and about 25,000 gal of other organic compounds, including trichloroethane, trichloroethylene, perchloroethylene, toluene, and benzene. 


\section{Appendix B. Levels of Information Needed for Constructing Conceptual Models at Different Scales}

Regional-, subregional-, and local-scale models require different levels of descriptive information (table B1). For example, all three models require information about the distribution of the major rock types that compose the aquifer. In the eastern Snake River Plain, basalt is the most abundant rock type and has many different forms. For a regional-scale model (Garabedian, 1992) it may not be necessary to account explicitly for these different forms of basalt. However, for a subregional-scale model, it is meaningful to describe the general distribution of fractured, massive, and altered basalt. For a local- or facility-scale model, it may be necessary to describe the distribution of the many different forms of basalt and associated volcanic deposits that are present at any one place (Anderson and others, 1999).

Table B1. Information needed for constructing conceptual models at regional, subregional, and local scales.

$\begin{array}{cccc}\begin{array}{c}\text { Conceptual model } \\ \text { component }\end{array} & \begin{array}{c}\text { Regional Aquifer System Analysis, } \\ \text { regional-scale model }\end{array} & \begin{array}{c}\text { Idaho National Laboratory and vicinity, } \\ \text { subregional-scale model }\end{array} & \begin{array}{c}\text { Idaho National Laboratory facility, } \\ \text { local-scale model }\end{array}\end{array}$

Model boundaries Extent and saturated thickness of Northwestern extent of aquifer aquifer

Southwestern extent of waste solutes

Locations of stable hydraulic boundaries (northeastern zone of steep head gradients, southeastern regional flowline)

Saturated thickness of aquifer

Hydrogeologic framework

Distribution of hydraulic properties
Stratigraphy of regional geologic formations and groups

Distribution of major rock types (basalt; silicic rocks; clay, silt, sand, and gravel)
Hydrologic fluxes

Measured flux (Snake River gains and losses, spring flow)

Estimated flux (ground-water pumpage, irrigation return flow, stream and canal losses, tributary basin underflow, precipitation recharge)

Ground-water movement
Long-term (20 to 50 years) changes in climate and irrigation practices
Stratigraphy of regional geologic formations and groups Stratigraphy of composite basalt flows and basalt-flow groups

Distribution of hydrogeologic units (younger rocks, rocks of intermediate age, sediment, silicic rocks, older rocks)

Distribution of major rock types (fractured, dense, and altered basalt; silicic rocks; clay, silt, sand, and gravel)

Distribution of local stratigraphic units

Distribution of subregional geologic settings (rhyolite domes; sedimentary troughs; areas of subsidence, uplift, and dipping beds; volcanic rift zones and vent corridors)

Measured flux (streamflow infiltration from the Big Lost River channel, sinks, playas, and spreading areas)

Estimated flux (ground-water pumpage, irrigation return flow, ground water from or to adjacent parts of the aquifer, tributary-valley underflow, precipitation recharge, flow from underlying rocks)

Episodic and localized streamflow infiltration resulting from short-term ( 3 to 8 years) changes in climate
Extent of perched ground water

Locations of local hydraulic boundaries (flowline or distant specified head)

Local ground-water velocity field

Effective saturated thickness of aquifer (local confining unit below waste solutes)

Stratigraphy of individual basalt flows, basalt-flow groups, and sedimentary interbeds

Distribution of hydrogeologic units (local impeding layers or confining units)

Distribution of major rock types (thin or thick pahoehoe basalt flows; near-vent volcanic deposits; dikes; clay, silt, sand, and gravel)

Distribution of local stratigraphic units

Distribution of local geologic settings (vent corridors, sedimentary depositional environments)

Measured flux (streamflow losses in Big Lost River channel, sinks, playas, and spreading areas)

Estimated flux (ground-water pumpage, ground water from or to adjacent parts of the aquifer, infiltration of precipitation, injection and infiltration of wastewater, water-system leaks, landscape-watering return flow)

Thickness and orientation of preferential flowpaths (for example - fractures, lava tubes, etc.) 
Manuscript approved for publication, May 25, 2006

Prepared by the USGS Publishing Network,

Publishing Service Center, Tacoma, Washington

Bill Gibbs

Debra Grillo

Donita Parker

Sharon Wahlstrom

For more information concerning the research in this report, contact the

Director, Idaho Water Science Center

U.S. Geological Survey, 230 Collins Road

Boise, Idaho 83702

http://id.water.usgs.gov/ 


\section{$\mathbb{Z}$ 总}

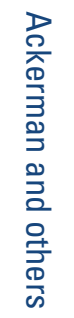

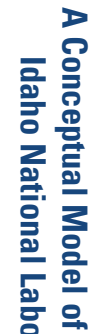

을 몽

음

른

종

를 끙

$\sum \Sigma$

王 官

흥

家

옥

部

윽 핫

ชั

言

극

흘 몽.

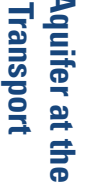

